\title{
Conservation Concerns for the Candy Darter (Etheostoma osburni) with Implications Related to Hybridization
}

Isaac Gibson

Follow this and additional works at: https://researchrepository.wvu.edu/etd

\section{Recommended Citation}

Gibson, Isaac, "Conservation Concerns for the Candy Darter (Etheostoma osburni) with Implications Related to Hybridization" (2017). Graduate Theses, Dissertations, and Problem Reports. 5673.

https://researchrepository.wvu.edu/etd/5673

This Thesis is protected by copyright and/or related rights. It has been brought to you by the The Research Repository @ WVU with permission from the rights-holder(s). You are free to use this Thesis in any way that is permitted by the copyright and related rights legislation that applies to your use. For other uses you must obtain permission from the rights-holder(s) directly, unless additional rights are indicated by a Creative Commons license in the record and/ or on the work itself. This Thesis has been accepted for inclusion in WVU Graduate Theses, Dissertations, and Problem Reports collection by an authorized administrator of The Research Repository @ WVU. For more information, please contact researchrepository@mail.wvu.edu. 
Conservation concerns for the Candy Darter (Etheostoma osburni) with implications related to hybridization

\title{
Isaac Gibson
}

Thesis submitted to the

Davis College of Agriculture, Natural Resources, and Design at West Virginia University

in partial fulfillment of the requirements for the degree of

Masters of Science in

Wildlife and Fisheries Resources

\author{
Amy B. Welsh, Ph.D., Chair
}

Stuart A. Welsh, Ph.D.

Daniel A. Cincotta, M.S.

Division of Forestry and Natural Resources

Morgantown, WV

2017

Keywords: hybridization, introgression, backcross, genetic swamping, hybrid zone, invasive, Etheostoma, osburni, variatum, New River, Gauley, Greenbrier, Distinct Population Segment, DPS 


\section{ABSTRACT \\ Conservation concerns for the Candy Darter (Etheostoma osburni) with implications related to hybridization}

\section{Isaac Gibson}

Candy Darters Etheostoma osburni and Variegate Darters E. variatum are both native to streams of West Virginia and Virginia. The geographic ranges of these two species were historically separated by Kanawha Falls, a natural barrier to fish dispersal located at Glen Ferris, WV. Habitat degradation may have reduced the geographic range of Candy Darters, a species of concern in West Virginia and Virginia as well as a federal species of concern. Currently, the species is undergoing a review for listing under the U.S. Endangered Species Act. In the early 1980s, Variegate Darters or putative hybrids were first collected at locations upstream of Kanawha Falls, and have since undergone range expansion. Genetic and morphologic data were examined for individuals from the New, Gauley, and Greenbrier river drainages. Individuals were genotyped using a suite of 5 microsatellite loci to investigate potential hybridization. There was strong evidence for the existence of Distinct Population Segments (DPS) of the Candy Darter. Widespread hybridization, however, was found throughout populations of the Candy Darter. A geographic hybrid zone was estimated with the highest levels of introgression representing the kernel of the hybrid swarm and the locations of F1 hybrids delineating the periphery. The F1 hybrid was meristically evaluated as intermediate within and across characters for parental species. Introgressive hybridization threatens the genetic integrity of the Candy Darter, and may lead to population extirpation and/or extinction. 


\section{ACKNOWLEDGEMENTS}

I would like to thank my graduate committee, Dr. Amy Welsh, Daniel Cincotta, and Dr. Stuart Welsh for review of my research and patient guidance; Dr. Stephanie Coster for thoughtful mentorship with concepts of genetics; Nathaniel Owens, David Okernick, Paul Robert, Dustin Kimble, and David Thorne for their dedicated assistance during field collections; the West Virginia Division of Natural Resources for funding; the Wild Genomics lab group for being a highly interactive and creative group of wonderful people to which I have been honored to be a part of; my wife Genevieve and son River whose love drive my ambitions; my parents, William Gibson and Catherine O'Dell, who I will always strive to make proud; my mother-in-law Dr. M. Deborah Larimer for taking such amazing care of our family during my academic pursuits; my father-in-law Dr. George Larimer for always believing in me and others; and Brian Johnston, Paul Poling, and Victor Robinson for their unique support and guidance. 


\section{TABLE OF CONTENTS}

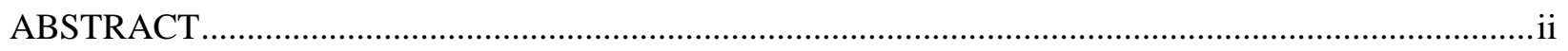

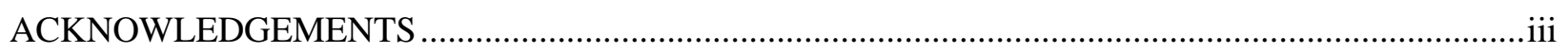

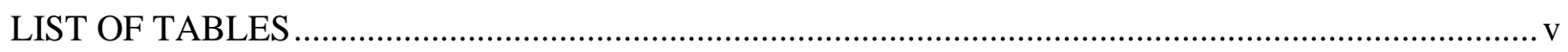

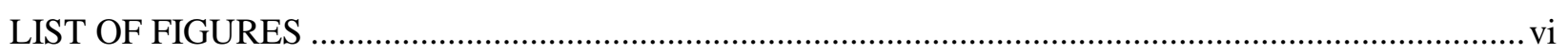

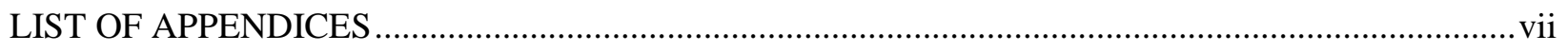

Chapter 1: Introduction and Literature Review .............................................................................. 1

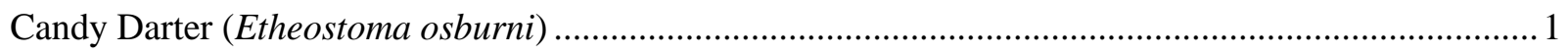

Variegate Darter (Etheostoma variatum) ...................................................................................... 2

History of E. variatum in New River Drainage ............................................................................... 2

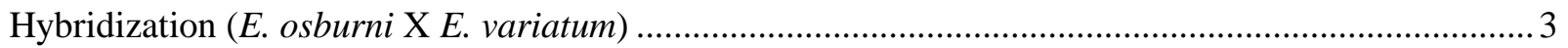

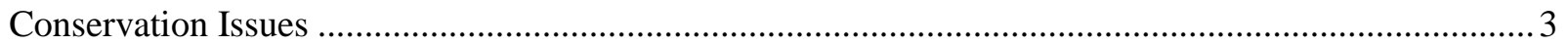

Chapter 2: Hybridization between Etheostoma osburni and Etheostoma variatum.................................. 6

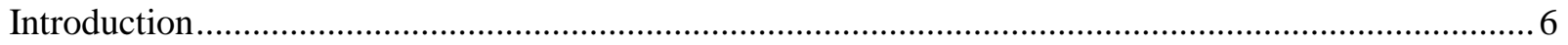

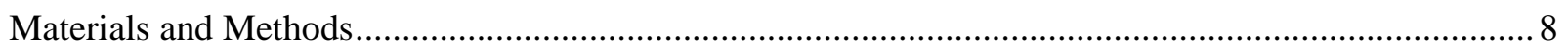

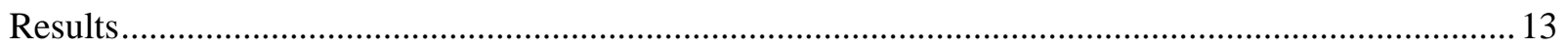

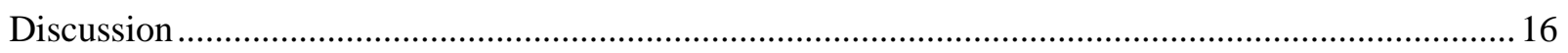

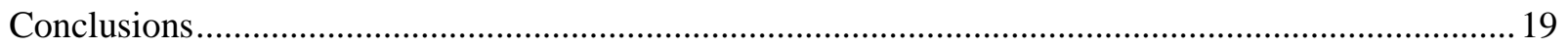

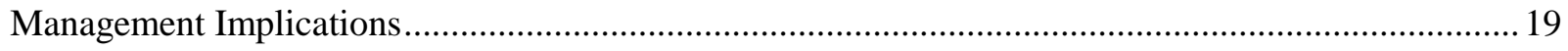

Chapter 3: Comparison of Etheostoma osburni between the Gauley and Greenbrier river drainages ...... 21

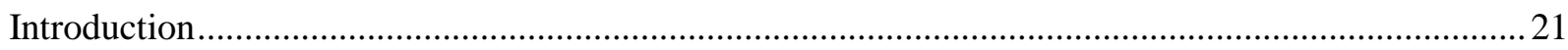

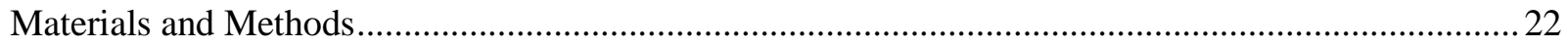

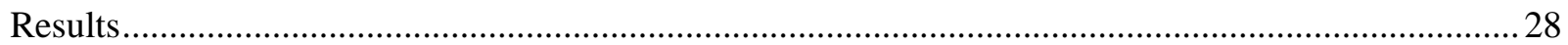

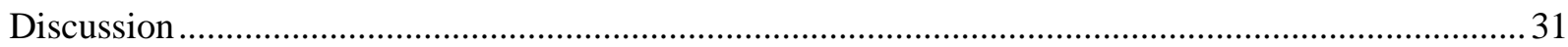

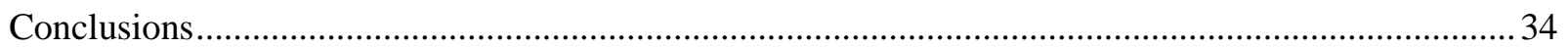

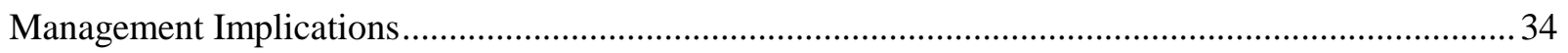

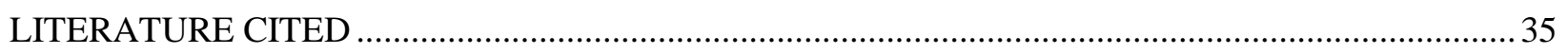

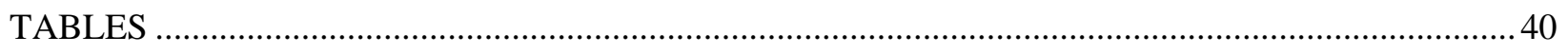

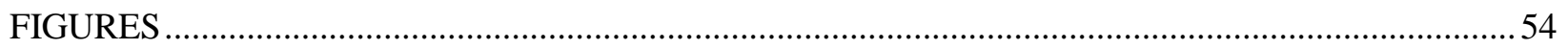

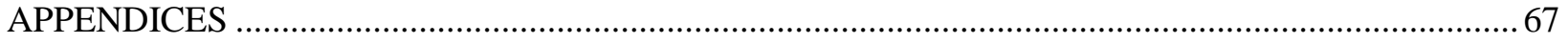




\section{LIST OF TABLES}

Table 1. List of collection sites enumerated to correspond with map of study area. Total number of specimens, number of pure E. osburni, and percentage of E. variatum alleles of that sample is given. All coordinates are in Zone 17.

Table 2. List of sites visited for this study that produced no specimens of either E. osburni or of hybrids.

All coordinates are in Zone 17.

Table 3. Meristic characters evaluated for F1 hybrids and for E. osburni (data for Gauley and Greenbrier populations of E. osburni is combined). Data for E. variatum is from Page (1983) and Page and

Burr (2011).

Table 4. Sites represented in each sample used in STRUCTURE analysis, construction of a neighborjoining tree, and for pairwise comparison of $\mathrm{F}_{\mathrm{ST}}$.

Table 5. Morphometric distances used in shape analysis of E. osburni. Variable enumeration corresponds to Figures 15 and 16. Box truss distance measurements, head length, outer-pelvic width, and caudal length $(1-23,26,31)$ are presented as thousandths of standard length. Measurements taken on the head $(24,25,27-30)$ are presented as thousandths of head length.. 44

Table 6. Meristic characters evaluated for Gauley and Greenbrier populations of E. osburni. Data for E. osburni from Page (1983) and Page and Burr (2011) is given.

Table 7. Results of HWE calculation for each population of E. osburni per locus and across all loci using Fisher's Method (Fisher 1935). Weir and Cockerham (1984) estimate of $F_{\text {IS }}$ is given. 47

Table 8. Results of HWE calculation for each sample of E. osburni (as described in Table 4) per locus and across all loci using Fisher's Method (Fisher 1935). Weir and Cockerham (1984) estimate of $\mathrm{F}_{\mathrm{IS}}$ is given.......

Table 9. Pairwise comparison of $\mathrm{F}_{\mathrm{ST}}$ among samples (as described in Table 4; above the diagonal) with P-values obtained after 900 permutations (below the diagonal). Indicative adjusted nominal level (5\%) for multiple comparisons is 0.001 . Significant values are listed in bold font.

Table 10. Allelic frequency for the Gauley and Greenbrier populations of E. osburni $\left(\mathrm{n}_{\text {Gauely }}=67\right.$; $\mathrm{n}_{\text {Greenbrier }}=144 ; \mathrm{n}_{\text {Total }}=211$ ). The status as a private allele is indicated.

Table 11. Summary of allelic variation of Gauley and Greenbrier populations of E. osburni including number of alleles, allelic size range, allelic richness, observed heterozygosity $\left(\mathrm{H}_{\mathrm{o}}\right)$, and expected heterozygosity $\left(\mathrm{H}_{\mathrm{e}}\right)$.

Table 12. Summary of 20 repeated measurements on a single individual for error quantification of morphometric distances. All values are presented in millimeters. 


\section{LIST OF FIGURES}

Figure 1. Distribution records of E. osburni in West Virginia from 1931 - 2015 (WVDNR unpublished data).

Figure 2. Distribution records of E. variatum morphometrically identified in the New River drainage, West Virginia from 1982 - 2014 (WVDNR unpublished data). These data do not include genetic detection of $E$. variatum alleles of the current study.

Figure 3. Collection sites for materials used in this study. Site labels correspond with Table 1. .56

Figure 4. Photograph depicting typical cephalic squamation of Etheostoma variatum. One scale patch is shown on the opercle. Two scale patches are shown in the supraopercular region. Etheostoma osburni X Etheostoma variatum may possess any or none of these scale patches.

Figure 5. STRUCTURE diagram depicting posterior probability of assignment (vertical axis) for all individuals collected at $\mathrm{K}=2$. Samples $1-10$ are comprised of pure E. osburni. Horizontal axis is sample location number. .58

Figure 6. STRUCTURE diagram depicting posterior probability of assignment (vertical axis) for $E$. osburni at $\mathrm{K}=2$. Samples $3-8$ are from the Gauley River drainage. Samples 1, 2, 9, and 10 are from the Greenbrier River drainage. Horizontal axis is sample location number. .58

Figure 7. Posterior probability of assignment (vertical axis) to six classifications: E. osburni, E. variatum, F1 hybrid, F2 hybrid, backcross with E. osburni, and backcross with E. variatum. Site numbers (horizontal axis) correspond to Table 1. Elevation in each drainage increases with distance from the dashed line. The relative location of Summersville Dam is indicated.

Figure 8. Etheostoma variatum alleles detected during this study (open diamonds). Solid circles indicate the presence of pure E. osburni in a sample. Open circles indicate the collection location of first generation (F1) hybrids of E. osburni X E. variatum. The proportion of E. variatum alleles within each sample where $E$. variatum alleles were detected is labeled.

Figure 9. Etheostoma osburni X Etheostoma variatum. $71 \mathrm{~mm}$ SL male, Deer Creek (Site 19), Pocahontas Co., WV, 7 March 2017. Photograph by Dr. Stuart A. Welsh.... 61

Figure 10. Etheostoma osburni X Etheostoma variatum. $68 \mathrm{~mm}$ SL female, Deer Creek (Site 19), Pocahontas Co., WV, 7 March 2017. This individual was gravid at the time of collection. Photograph by Dr. Stuart A. Welsh.

Figure 11. Etheostoma osburni. $78 \mathrm{~mm}$ SL male, East Fork Greenbrier River, Pocahontas Co., WV, 4 April 2016. Photograph by Dr. Stuart A. Welsh.....

Figure 12. Etheostoma osburni. $65 \mathrm{~mm}$ SL female, Little River East Fork Greenbrier River, Pocahontas Co., WV, 28 March 2017. Photograph by Dr. Stuart A. Welsh. 
Figure 13. Etheostoma variatum. $66 \mathrm{~mm}$ SL male, Twentymile Creek, Nicholas Co., WV, 19 April 2017. Photograph by Dr. Stuart A. Welsh.

Figure 14. Etheostoma variatum. $57 \mathrm{~mm}$ SL female, Twentymile Creek, Nicholas Co., WV, 19 April 2017. Photograph by Dr. Stuart A. Welsh.

Figure 15. Box truss network comprised of 23 distances for morphometric analysis of E. osburni and $E$. osburni X E. variatum. Numeric labels correspond to Table 5.

Figure 16. Supplemental distances for morphometric analysis of E. osburni and E. osburni X E. variatum. Labels correspond to Table 5.

Figure 17. Neighbor-joining tree based on 1000 generated trees. Values presented are percents of 1000 generated trees that group the samples together. The drainage to which each sample belongs is labeled in parentheses. Members of each sample are described in detail in Table 4.

Figure 18. Plots of the sheared second and third principal components (SPC2 and SPC3) that depict shape differences between the Gauley (triangles) and Greenbrier (circles) populations of $E$. osburni.

\section{LIST OF APPENDICES}

Appendix 1. Posterior probability of assignment to six species/hybrid classifications. Site numbers that are listed correspond to Table 1. Each row represents an individual $(n=335)$. 


\section{Chapter 1: Introduction and Literature Review}

The closely related Candy Darter (Etheostoma osburni; Hubbs and Trautman 1932) and Variegate Darter (E. variatum; Kirtland 1840) are native to West Virginia and endemic to the Ohio River drainage of North America. The geographic ranges of these two species were historically separated by Kanawha Falls, a natural barrier to fish dispersal located at Glen Ferris, WV (Hocutt and Wiley 1986; Stauffer 1995; Page and Burr 2011). This biogeographic barrier, which blocked upstream dispersal of $E$. variatum, is thought to have allowed the two populations of darters to form the extant populations of $E$. osburni and E. variatum through allopatric speciation.

Etheostoma variatum was introduced upstream of Kanawha Falls which created an additional conservation concern for E. osburni (Cincotta et al. 1999; Wellman 2004; Burns 2007). Most likely, E. variatum was introduced from one or many anglers' bait buckets. Bait bucket introduction is a common progenitor of invasive fish and other aquatic organisms (Litvak and Mandrak 1993; Ludwig and Leitch 1996; Lintermans 2004; Rahel 2007; Loughman and Welsh 2010). Hybridization of these two species has been documented (Switzer et al. 2004; Switzer et al. 2007). This hybridization and subsequent introgression may lead to the extirpation and/or extinction of E. osburni (Switzer et al. 2007).

\section{Candy Darter (Etheostoma osburni)}

Etheostoma osburni is endemic to the upper Kanawha River system upstream of Kanawha Falls. Its range includes the Gauley and Greenbrier rivers of West Virginia and the New River within West Virginia and Virginia (Jenkins and Burkhead 1994; Stauffer et al. 1995). Within West Virginia, historic distribution records have documented this species throughout the Gauley, Greenbrier, and Bluestone rivers, and Indian Creek of the New River drainage (Figure 1). Etheostoma osburni is a brilliantly colored, benthic fish of the family Percidae. It is found in small streams and midsize rivers. This darter primarily occupies the loose rubble and boulder substrate of silt free riffle habitat (Chipps et al. 1994; Dunn and Angermeier 2016). Etheostoma osburni feeds opportunistically on benthic macroinvertebrates. Mayflies (Ephemeroptera) comprise the majority of their diet (Schoolcraft et al. 2007). Schoolcraft and 
Tarter (2002) estimated April 21 as the approximate peak spawning time of E. osburni in the South Fork of the Cherry River. Jenkins and Burkhead (1994) documented a significant reduction in the range of $E$. osburni in Virginia in recent history. Due to limited distribution and population reduction, E. osburni is listed as a species of concern in West Virginia, a species of special concern in Virginia, and a federal species of concern (USFWS 1989; Jelks et al. 2008).

\section{Variegate Darter (Etheostoma variatum)}

Etheostoma variatum is closely related to E. osburni. They both belong to the subgenus Etheostoma and are members of the variatum complex (Hubbs and Black 1940). In addition to E. osburni and E. variatum, the variatum complex also includes: Etheostoma euzonum (Hubbs and Black 1940), E. erythrozonum (Switzer and Wood 2009), E. kanawhae (Raney 1941), and E. tetrazonum (Hubbs and Black 1940). Etheostoma variatum commonly occurs over a relatively large area of the Ohio River drainage including the Kanawha River drainage below Kanawha Falls (Stauffer et al. 1995) and excluding the Wabash and Tennessee River systems (Hubbs and Black 1940); within this range it occurs in Indiana, Kentucky, New York, Ohio, Pennsylvania, and West Virginia. Like E. osburni, the habitat of this darter is primarily comprised of the rubble and boulder substrate of riffle habitat in small streams and midsize rivers. Etheostoma variatum subsists on a diet of benthic macroinvertebrates. May (1969) estimated the approximate spawning activity of E. variatum to occur during the period of April 15 to May 10 .

\section{History of $E$. variatum in New River Drainage}

In 1982, a specimen of E. variatum was collected from New River at Sandstone Falls (D.

Cincotta, pers. comm.). This was the earliest known record of E. variatum collected upstream of Kanawha Falls (i. e. in the New River drainage; Figure 2). In the 1990s, specimens of E. variatum were collected from Anthony Creek, a tributary to the Greenbrier River (D. Cincotta, pers. comm.). At this time, both species were sympatric at this location in Anthony Creek. Wellman et al. (2004) collected E. variatum while surveying the ichthyofauna of the New River. Switzer (2004) found evidence that $E$. osburni and E. variatum were potentially hybridizing in the New River drainage. Switzer et al. (2007) found strong evidence of hybridization between these two species and found no first generation (F1) 
hybrids or E. osburni at Anthony Creek implying that E. osburni had been swamped out, or replaced, by hybridization with E. variatum at this site (Avise 2004). This study indicated Anthony Creek as the upstream-most extent of hybridization in the Greenbrier River drainage; no evidence of hybridization upstream of Anthony Creek was found. Switzer et al. (2007) also found no evidence of hybridization in the Gauley River drainage upstream of Summersville Dam.

\section{Hybridization (E. osburni X E. variatum)}

Etheostoma variatum is known to hybridize with E. osburni (Switzer et al. 2007). Hybridization, in this context, occurs when two different species mate and produce offspring that possess genes from both parental species. Etheostoma variatum or hybrid (E. variatum X E. osburni) individuals have been identified at locations within the range of E. osburni (Cincotta et al. 1999; Wellman 2004). Switzer et al. (2007) found genetic evidence of introgression of E. variatum within populations of E. osburni in the New River drainage. Introgression is the incorporation of genes from one population into another population through progressive hybridization and backcrossing (Harrison and Larson 2014). Introgression is possible when the product of interspecific hybridization is viable offspring. The viable offspring are able to mate with other hybrids or parental species which allows the movement of genes between populations. Introgressive hybridization seems to be replacing populations of E. osburni with populations of E. variatum hybrids (Rhymer and Simberloff 1996; Matthews et al. 2016). This progressive genetic swamping is a primary threat to all E. osburni populations.

\section{Conservation Issues}

Etheostoma osburni has a limited national distribution and its range is shrinking (Chipps et al. 1993; Jenkins and Burkhead 1994). Due to its limited range, the species has been designated as a Species of Concern in West Virginia, a Species of Special Concern in Virginia, and a Federal Species of Concern. Etheostoma osburni is a candidate for listing under the U.S. Endangered Species Act (Douglas, pers. comm.). Portions of the New, Gauley, and Greenbrier river drainages have been invaded by E. variatum. A successful conservation strategy for the imperiled E. osburni requires a thorough understanding of the dynamics of hybridization between these two species. 
Hybridization with introgression is one mechanism that can cause the extinction of native species (Rhymer and Simberloff 1996). Introgressive hybridization between E. osburni and E. variatum is occurring throughout the Gauley (below Summersville Dam), Greenbrier, and New (below Bluestone Dam) river drainages in West Virginia. All of the populations of E. osburni within this distribution have become or are threatened with imminent genetic extinction. The populations of E. osburni in these drainages that have not already been lost will most likely disappear due to introgression with E. variatum.

Hybrids of Candy and Variegate darters have not been thoroughly examined. It is important to be able to identify individuals of hybrid origin based on visual inspection, providing a valuable marker in determining the zone of hybridization and detecting this occurrence in other regions. Due to the varying degrees of hybridization (first generation, second generation, backcrosses, etc.) affecting the identification of these two closely related species, relying on morphologic identification alone can be problematic. It was necessary to, first, utilize genetic techniques to thoroughly assess populations of the subject fishes and identify individuals with hybrid ancestry for morphological analysis and to identify pure E. osburni for evaluation. The current geographic extent of hybridization needed to be surveyed. A genetic assay of hybridization was performed by Switzer et al. (2007), which identified Anthony Creek as the upstream extent of introgression with E. variatum in the Greenbrier River drainage. Individuals collected upstream of Anthony Creek did not exhibit evidence of hybridization in 2004. Switzer et al. (2007) further indicated the importance of monitoring above Anthony Creek for upstream evidence of introgression. Increasing sample sizes rather than increasing the number of genetic markers increases the probability of detecting non-native alleles (Della Croce et al. 2017). It is important to identify where unaffected populations of E. osburni occur so that conservation efforts may focus on those areas. Chapter 2 of this thesis reports on the current extent of hybridization between these two species and discusses meristic characters of the F1 hybrid. Switzer et al. (2007) found evidence of genetic divergence between the Gauley and Greenbrier river drainage populations of E. osburni. Due to genetic differences between populations, a loss of one population will result in the loss of genetic diversity for the species as a whole. Chapter 3 emphasizes the genetic and morphometric differences between the populations of E. osburni in 
West Virginia. This study focuses on the populations of E. osburni in West Virginia. It should be noted that $E$. variatum has yet to be reported in the New River drainage of Virginia where other investigations of E. osburni have been conducted by Leftwich et al. (1994); Angermeier (1995); Leftwich et al. (1996); Angermeier and Pinder (2015); and Dunn and Angermeier (2016). 


\section{Chapter 2: Hybridization between Etheostoma osburni and Etheostoma variatum}

\section{Introduction}

In recent studies, E. variatum was found to have been introduced within the range of E. osburni (Cincotta et al. 1999; Wellman 2004; Burns 2007). The most likely method of introduction is the release of E. variatum individuals from one or many anglers' bait buckets. Bait bucket introduction is a common progenitor of invasive fish and other aquatic organisms (Litvak and Mandrak 1993; Ludwig and Leitch 1996; Lintermans 2004; Rahel 2007; Loughman and Welsh 2010). Hybridization of these two species in the New River drainage has been documented (Switzer et al. 2007). This hybridization and subsequent introgression may lead to population extirpation and/or extinction of E. osburni (Switzer et al. 2007).

In 1982, a specimen of E. variatum was collected from New River at Sandstone Falls (D. Cincotta, pers. comm.). This was the earliest known record of E. variatum collected upstream of Kanawha Falls (i. e. in the New River drainage). In the 1990s, specimens of E. variatum were collected from Anthony Creek, a tributary to the Greenbrier River (D. Cincotta, pers. comm.). At this time, both species were sympatric at this location in Anthony Creek. E. variatum individuals continued to be collected from New River in 1997 (Cincotta et al. 1999). Wellman et al. (2004) collected E. variatum while surveying the ichthyofauna of the New River.

Switzer (2004) found evidence that E. osburni and E. variatum were potentially hybridizing in the New River drainage. Subsequently, Switzer et al. (2007) found strong evidence of hybridization between these two species. That study found no first generation (F1) hybrids or E. osburni at Anthony Creek implying that E. osburni had been swamped out, or replaced, by hybridization with E. variatum at this site. Switzer et al. (2007) indicated Anthony Creek as the upstream-most extent of hybridization in the Greenbrier River drainage; no evidence of hybridization above Anthony Creek was found. They also found no evidence of hybridization in the Gauley River drainage upstream of Summersville Dam.

Hybridization with introgression is one mechanism that can cause the extinction of native species (Rhymer and Simberloff 1996). The breakdown of species boundaries through introgressive hybridization resulting in a loss of species diversity has been reported in a variety of fish families such as 
Cichlidae, Gasterosteidae, Salmonidae, and Cyprinidae (Seehausen et al. 1997; Taylor 2006; Muhlfeld et al. 2009; Almodóvar et al. 2012). Introgression as a cause of loss of genetic and species diversity has been observed in other darters (Percidae: Etheostoma; Halas and Simons 2014; Matthews et al. 2016). This erosion of species boundary and attrition of biodiversity is occurring throughout the Gauley and Greenbrier populations of E. osburni. The populations of E. osburni within this distribution have become or are threatened with imminent genetic extinction. The populations in these drainages that have not already disappeared will most likely disappear due to introgression with E. variatum.

Etheostoma osburni has a limited national distribution and its range is shrinking (Chipps et al. 1993; Jenkins and Burkhead 1994; WVDNR unpublished data). Due to its limited range, the species has been designated as a Species of Concern in West Virginia, a Species of Special Concern in Virginia, and a Federal Species of Concern. Etheostoma osburni is a candidate for listing under the U.S. Endangered Species Act (Douglas, pers. comm.). A successful conservation strategy for the imperiled E. osburni requires a thorough understanding of the dynamics of hybridization between these two species.

Hybrids of Candy and Variegate darters have not been thoroughly examined. It is important to be able to identify individuals of hybrid origin based on visual inspection, providing a valuable marker in determining the zone of hybridization and detecting this occurrence in other regions. Due to the varying degrees of hybridization (first generation, second generation, backcrosses, etc.) affecting the identification of these two closely related species, relying on morphologic identification alone can be problematic. It was necessary to, first, utilize genetic techniques to thoroughly assess populations of the subject fishes and identify individuals with hybrid ancestry for morphological analysis and to identify pure E. osburni for evaluation. The current geographic extent of hybridization needed to be surveyed. A genetic assay of hybridization was performed by Switzer et al. (2007), which identified Anthony Creek as the upstream extent of introgression with E. variatum in the Greenbrier River drainage. Individuals collected upstream of Anthony Creek did not exhibit evidence of hybridization in 2004. That study indicated the importance of monitoring above Anthony Creek for upstream evidence of introgression. Increasing sample sizes rather than increasing the number of genetic markers increases the probability of detecting non-native 
alleles (Della Croce et al. 2017). This study utilized large sample sizes distributed over a broad range within the Gauley and Greenbrier river drainages to delineate where unaffected populations of E. osburni occur within West Virginia. These data are important to conservation efforts that will attempt to preserve this species. Hence, the objectives of this study were to 1) synthesize and map distributional data for $E$. variatum introgression in the Gauley and Greenbrier populations of E. osburni and 2) describe meristic characters of E. osburni X E. variatum hybrids

\section{Materials and Methods}

\section{Collection and Preservation}

Tissue samples and potential morphometric specimens $(n=335)$ were collected from 22 of 45 sampling locations (Table 1; Figure 3). Sites that did not produce specimens are listed in Table 2. For sampling, a field technician, outfitted with a backpack electrofishing unit and two forward-facing wands, shocked in a downstream fashion towards a seine net ( $5 \mathrm{ft} \times 10 \mathrm{ft} \times 3 / 16 \mathrm{in} ; 1.24 \mathrm{~m} \times 3.05 \mathrm{~m} \times 4.76 \mathrm{~mm}$ ). The seine net was placed approximately $5 \mathrm{~m}$ below the technician. Two additional field technicians flanked the electrofisher to disrupt the substrate. A series of intertransects that were parallel to the direction of the stream current were followed until nearly full coverage of the riffle habitat for that reach was attained or a minimum of 30 individuals was obtained, whichever occurred first. Multiple riffles in some extended reaches were sampled to increase sample size when E. osburni was sparse.

A tissue sample was taken from the right pelvic fin from each individual for genetic analysis. Fin clips were placed in $99 \%$ ethyl alcohol, and then the entire fish was placed in 10\% formalin. Specimen labels were created to identify individuals and link genetic data to morphometric specimens. Formalin in specimen containers was discarded after at least six months and replaced with water. The water was replaced with fresh water once per day for four consecutive days after which the containers were filled with $45 \%$ isopropyl alcohol. 


\section{Genetic Characterization}

Switzer et al. (2008) developed a set of 15 polymorphic microsatellite DNA markers for examining genetic variation within populations and potential hybridization between E. osburni and $E$. variatum. Five of these microsatellite loci (Eos-C2, Eos-C3, Eos-C6, Eos-C112, and Eos-C117) were found to be diagnostic in the differentiation between the two species. This set of diagnostic loci was instrumental in detecting hybridization and verifying the purity of species of individuals. Primers for these loci were manufactured by and obtained from Integrated DNA Technologies.

Total genomic DNA was extracted with the Promega SV 96 Genomic DNA Purification System following a modified version of the "Animal Tissues" protocol (Promega Technical Bulletin Part \#TB303). Approximately $4 \mu \mathrm{g}( \pm 2 \mu \mathrm{g}$; or approximately $1 \mathrm{~mm} \mathrm{X} 2 \mathrm{~mm})$ of pelvic fin tissue per specimen was prepared in each well of a 96 -well plate for a 16 hour digestion at $55^{\circ} \mathrm{C}$. The elution process consisted of two $50 \mu \mathrm{L}$ elutions (for a total elution volume of $100 \mu \mathrm{L}$ ) and was performed with a combination of vacuum and centrifugation. Concentrations of extracted DNA were quantified with a NanoDrop Lite spectrophotometer. A dilution $(10 \mathrm{ng} / \mu \mathrm{L})$ of each extraction product was amplified using polymerase chain reaction (PCR).

Conditions of microsatellite PCR consisted of $20 \mathrm{ng}$ of genomic DNA, 0.4X QIAGEN Multiplex PCR Master Mix, and $0.2 \mu \mathrm{M}$ of each primer (with the forward primer fluorescently labeled) in a 10- $\mu \mathrm{l}$ final reaction volume. A C1000 Touch (BioRad) thermal cycler was used to conduct the PCR reaction that consisted of an initial denaturation at $95{ }^{\circ} \mathrm{C}$ for $15 \mathrm{~min} ; 25$ cycles of $94{ }^{\circ} \mathrm{C}$ denaturation for $30 \mathrm{~s}, 57$ ${ }^{\circ} \mathrm{C}$ annealing for $90 \mathrm{~s}, 72{ }^{\circ} \mathrm{C}$ extension for $60 \mathrm{~s}$; and a $60{ }^{\circ} \mathrm{C}$ final extension for $30 \mathrm{~min}$.

Capillary electrophoresis of PCR product ( $2 \mu \mathrm{L}$ per reaction) was conducted on a GenomeLab GeXP Genetic Analysis System (Beckman Coulter) with 400 bp size standard (0.5 $\mu$ L per reaction) and sample loading solution (27.5 $\mu \mathrm{L}$ per reaction). The associated software, GenomeLab GeXP Series Software Suite, was used to visualize analyzed fragments and manually score alleles to generate genotype data for each individual. ALLELOGRAM v2.2 (Manaster 2009) was used to normalize and bin alleles utilizing a positive control common to all capillary electrophoresis runs. 
Error of laboratory practices was evaluated. Ten percent of the tissue samples were selected with a random number generator. Each of these samples was extracted, amplified, visualized, and scored again according to the aforementioned practices. These data were compared to those of the original series to identify inconsistencies between allele scoring. Error rates were summarized as the number of inconsistently scored alleles divided by the total number of alleles.

Error of allele scoring was evaluated. A random number generator was used to select 47 (14\%) of the original capillary electrophoresis results. The corresponding electropherograms were cross-read by another researcher to independently score alleles. These data were compared to the original data to identify inconsistencies between allele scoring. A discrepancy between original and independently scored alleles was interpreted as potential error and summed. Error rates were summarized as the number of inconsistently scored alleles divided by the total number of alleles.

The potential for null alleles was investigated with MICROCHECKER v2.2.3 (Van Oosterhout et al. 2003). Default settings were used with a maximum expected allele size of $500 \mathrm{bp}$, a $95 \%$ confidence interval, and 1000 randomizations. Each population identified during the STRUCTURE analysis was investigated independently. The software GENEPOP v4.2 (Raymond and Rousset 1995) was used to determine the status of Hardy-Weinberg equilibrium (HWE) of populations defined during the STRUCTURE analysis. A probability test for each locus in the population was conducted to estimate exact P-values with the Markov chain method. The following Markov chain parameters were used: Dememorization number $=1000 ; 100$ batches; and 1000 iterations per batch. The significance level was set at $\alpha=0.05$.

The purity and admixture of each specimen was manually verified by examining the five diagnostic loci. If an individual possessed $E$. variatum alleles in any quantity, then it was considered to be a hybrid. It is possible that an individual may have accumulated only E. variatum alleles at each of the diagnostic loci through progressive introgression. Switzer et al. (2007) discovered individuals that possessed only E. variatum alleles at the diagnostic loci but possessed a haplotype of the cytochrome b gene that indicated hybrid ancestry. One of the main intentions of this study was to identify pure $E$. 
osburni by reasonably ruling out the possibility of hybridization and, so, there were considered to be two categories of fish, pure E. osburni and non-pure E. osburni. Hence, fully E. variatum nuclear genotypes that may have arisen through a history of hybrid ancestry were referred to as hybrids in this study.

Individuals that possessed one E. osburni allele and one E. variatum allele at each of the 5 diagnostic loci were considered to be F1 hybrids.

The number of independently operating genetic clusters or populations (K) was inferred with STRUCTURE v2.3.4 (Pritchard et al. 2000). The initial analysis was conducted on the entire microsatellite data set representing 335 individuals. Ten independent runs for each $\mathrm{K}$ from $\mathrm{K}=1$ to $\mathrm{K}=$ 13 with 100,000 Markov Chain Monte Carlo (MCMC) iterations and a burn-in period of 100,000 generations were performed. The default settings which included correlated allele frequencies, assumed admixture, and no prior information were used. STRUCTURE HARVESTER v0.6.94 was used to visualize the STRUCTURE results and implement the $\Delta \mathrm{K}$ method of Evanno et al. (2005) to determine the number of $\mathrm{K}$ at the highest level of genetic partitioning (Earl and vonHoldt 2012). The composition of each population was determined by assigning individuals to populations based on affinity for the cluster representing hybrids. If an individual had an admixture proportion $q \geq 0.994$ for the cluster representing E. osburni then it was assigned to that cluster; otherwise, it was assigned to the cluster representing hybrids. This admixture proportion was selected because it was found, upon manual inspection of the diagnostic loci, that individuals with lower admixture proportions $(\mathrm{q}<0.994)$ possessed E. variatum alleles. Individuals that comprised the clusters were manually corroborated with microsatellite data to search for the presence of E. variatum alleles. The initially identified population of hybrids was not investigated for substructure. A recursive, hierarchical approach to investigate substructure, or deeper delineation of populations, was implemented. A subsequent STRUCTURE analysis with 10 independent runs for each $\mathrm{K}$ from $\mathrm{K}=1$ to $\mathrm{K}=12$ with 100,000 Markov Chain Monte Carlo (MCMC) iterations and a burn-in period of 100,000 generations was conducted on the E. osburni cluster. Each subsequently identified population was investigated in the same fashion. 
NewHybrids v1.1 Beta 3 (Anderson and Thompson 2002) was used to estimate the posterior probability of the classification of genotyped individuals. Classifications were defined as E. osburni, E. variatum, F1 hybrid, F2 hybrid, backcross with E. osburni, and backcross with E. variatum. An individual was required to have a posterior probability of classification of $\mathrm{P} \geq 0.998$ for E. osburni; otherwise, it was assigned to the classification with the next highest posterior probability. This value was used because a natural break in the continuity of posterior probabilities occurs at $\mathrm{P}=0.998$ and because every individual with a probability $\mathrm{P}<0.998$ for E. osburni classification was discovered to have at least one E. variatum allele upon manual inspection of the genotype. Individuals were required to have a posterior probability of classification of $\mathrm{P} \geq 0.650$ for $\mathrm{F} 1$ hybrid; otherwise, it was assigned to the next highest probability of classification. The individuals with strong assignment $(\mathrm{P} \geq 0.680)$ to backcross with E. osburni were considered to be the result of F1 hybrid backcross with E. osburni whereas individuals with weak assignment $(\mathrm{P} \leq 0.230)$ were considered to be the result of multigenerational backcrossing with E. osburni. This method was designed by corroboration with manual inspection of genotypes, follows natural breaks in the continuity of posterior probabilities, and imposes the strictest rules for assignment of backcrosses with E. osburni and assignment of F1 hybrids.

\section{Meristics}

Meristic data from F1 hybrids (two males and two females) were compared with those of 41 individuals of pure E. osburni males. The F1 specimens represent one male and one female each from the Gauley and Greenbrier river drainages. The E. osburni individuals were collected from 12 sites in the Gauley and Greenbrier river drainages for a concurrent study (Table 3). Sex was determined by examining genital papillae and supported by male nuptial characters such as thickened fins, enlarged scale margins, and concentrations of pigment. Data for 14 meristic variables were recorded: dorsal-fin spines, dorsal-fin rays, pectoral-fin rays, pelvic-fin rays, pelvic-fin spines, anal-fin rays, anal-fin spines, scales above lateral line, scales below lateral line, scales along lateral line (left), scales along lateral line (right), circumpeduncle scales, dark lateral bars, and dorsolateral saddles. Presence-absence data were recorded for five variables: dorsal-fin saddle, breast squamation (embedded), breast squamation (exposed), opercle 
squamation, and supraopercular squamation. The dorsolateral saddle that occurs beneath the first dorsal fin was counted separate from the other saddles. Supraopercular squamation may occur in the dorsolateral region of the head above the opercle (Figure 4). The minimum, maximum, and mode values for meristic variables are reported.

\section{Results}

\section{Genetic Characterization}

Ten percent of the original tissue samples were randomly selected and extracted, amplified, visualized, and scored again for comparison to original scores. The validation process yielded results that were identical to the corresponding original data; therefore, an error rate of zero was attributed to laboratory practices.

Fourteen percent (47 of the total 335) of the electropherograms were cross-read for error quantification of allele scoring. Of these data, 6 of $470(0.013)$ alleles were scored differently by an independent researcher. These differences represented four alleles at two loci in three individuals. By locus, there were no allelic discrepancies found at Eos-C2, Eos-C3, and Eos-C6; Eos-C6 yielded an error rate of 0.021; and Eos117 yielded an error rate of 0.043. At this error rate, we would expect approximately 43 possible allelic discrepancies within the total of 3350 alleles. None of these discrepancies resulted in scoring alleles that would misassign an individual to species or hybrid class nor did any of the discrepancies result in novel alleles for that sample. This error rate was considered to be acceptable.

The MICROCHECKER analysis found no evidence for scoring error due to stuttering, no evidence for large allele dropout, and no evidence of null alleles at any of the loci in the Gauley and Greenbrier populations. There was a general excess of homozygotes found in the population of hybrids at Eos $-C 3($ exp. $=29.895$, obs. $=50)$, Eos-C112 (exp. = 80.798, obs.=95), and Eos-C2 $(\exp .=50.048$, obs.=62). All of the loci that comprised the population of hybrids were significantly out of HWE: Eos- 
$C 2\left(\mathrm{~F}_{\mathrm{IS}}=0.1656, \mathrm{P}=0.001\right)$, Eos $-C 3\left(\mathrm{~F}_{\mathrm{IS}}=0.2175, \mathrm{P}<0.000\right)$, Eos $-C 6\left(\mathrm{~F}_{\mathrm{IS}}=0.0662, \mathrm{P}=0.005\right)$, Eos-

C112 ( $\left.\mathrm{F}_{\mathrm{IS}}=0.3323, \mathrm{P}<0.000\right)$, and Eos $-C 117\left(\mathrm{~F}_{\mathrm{IS}}=0.1045, \mathrm{P}<0.000\right)$.

A total of 335 individuals from the Gauley and Greenbrier river drainages were genotyped. Of this total, 124 genotypes included alleles within the size range of E. variatum discovered during manual inspection. The initial STRUCTURE run revealed $\mathrm{K}=2$ at the highest level of genetic partitioning which represented E. osburni and the cluster of hybrids that comprised the hybrid swarm $(\mathrm{n}=124)$ (Figure 5). A secondary run that included individuals assigned to the population of E. osburni revealed substructuring within this species (Figure 6). It was found that $\mathrm{K}=2$ within E. osburni which represented a distinction between the two populations of the Gauley and Greenbrier river drainages. No additional substructuring was found within these two populations of E. osburni. This phenomenon is discussed in more detail in Chapter 3. Substructuring was not investigated for the population of hybrids.

Posterior probability of assignment to six classes for each individual was calculated (Figure 7; Appendix 1). Three individuals from the Gauley River drainage upstream of Summersville Dam (Sites 4 - 11) had probabilities of assignment to backcross with E. osburni $(0.227 \leq \mathrm{P} \leq 0.180)$. All other individuals from the Gauley River drainage above Summersville Dam assigned to E. osburni (P $\geq 0.998)$. All individuals from Gauley River (Site 2), Bells Creek (Site 1), Greenbrier River (Site 12), and Anthony Creek (Sites 13, 14, and 15) assigned to E. variatum or backcross with E. variatum $(\mathrm{P}>0.500)$ except for three individuals that assigned to F1 hybrid (P > 0.650; Site 2) and another individual that assigned to backcross with E. osburni $(\mathrm{P}=0.321)$. One individual from Knapp Creek (Site 16) assigned to F1 hybrid $(\mathrm{P}=0.660)$; one individual assigned to $E$. osburni $(\mathrm{P}=0.997)$; two individuals assigned to backcross with E. osburni $(\mathrm{P} \geq 0.776)$; and one individual assigned to E. variatum $(\mathrm{P}=0.994)$. All individuals from Knapp Creek (Site 17) assigned to E. osburni ( $\mathrm{P} \geq 0.999)$ except one individual that assigned to backcross with E. osburni $(\mathrm{P}=0.146)$. All individuals from Sitlington Creek (Site 18) assigned to E. osburni $(\mathrm{P} \geq$ 0.998) except one individual that assigned to backcross with E. osburni $(\mathrm{P}=0.149)$. One individual from Deer Creek (Site 19) assigned to F1 hybrid; 2 individuals had strong assignment to backcross with $E$. osburni ( $\mathrm{P} \geq 0.827)$; one individual assigned to backcross with E. osburni $(\mathrm{P}=0.181)$; and eight 
individuals assigned to E. osburni ( $\mathrm{P} \geq 0.999)$. All individuals from East Fork Greenbrier River (Site 20) assigned to E. osburni ( $\mathrm{P} \geq 0.998)$. All individuals from Little River East Fork Greenbrier River assigned to E. osburni ( $\mathrm{P} \geq 0.998)$ except two individuals that assigned to backcross with E. osburni $(\mathrm{P} \geq 0.054)$. All individuals from West Fork Greenbrier River assigned to E. osburni ( $\mathrm{P} \geq 0.998)$ except one that assigned to backcross with E. osburni $(\mathrm{P}=0.893)$.

\section{Geographic Distribution of Hybrids}

Locations of E. variatum alleles, \% E. variatum alleles, numbers of specimens collected, and numbers of pure E. osburni collected at each site were determined (Table 1; Figure 8). E. variatum alleles were detected at two locations in the Gauley River drainage above Summersville Dam (Sites 4 and 9, which are Cherry and Gauley rivers, respectively). One individual at Site 9 possessed one E. variatum allele and two individuals at Site 4 each possessed one E. variatum allele. All other individuals sampled from above Summersville Dam possessed only E. osburni alleles at the five diagnostic loci (i. e. pure E. osburni). The site immediately below Summersville Dam (Site 3) produced six individuals each with one E. variatum allele. Anthony Creek, Gauley River at the town of Swiss, and all sites between (Sites 1, 2, and 12 - 15) were characterized by populations comprised of at least $84.6 \%$ E. variatum alleles. None of these sites had any individuals that possessed only E. osburni alleles at each of the five diagnostic loci. F1 hybrid genotypes with a posterior probability of assignment $(\mathrm{P} \geq 0.650)$ as $\mathrm{F} 1$ hybrids were discovered at Sites 2, 16, and 19. The samples of darters at these three sites had $9.17 \%, 84.55 \%$, and $45.71 \% \mathrm{E}$. variatum alleles, respectively. One E. variatum allele in one individual was discovered in the sample of Sitlington Creek (Site 18). One individual sampled from Knapp Creek (Site 17) had one E. variatum allele; all other individuals possessed only E. osburni alleles. No E. variatum alleles were found in the sample of the East Fork Greenbrier River (Site 20). Two individuals from Little River East Fork Greenbrier River each had one E. variatum allele; all other individuals possessed only E. osburni alleles. One individual from West Fork Greenbrier River (Site 22) had three E. variatum alleles; all other individuals possessed only E. osburni alleles. 


\section{Meristic Characterization of F1 Hybrid}

Two male and two female F1 hybrids were meristically evaluated. This set of specimens represented a male and a female from each of the Gauley and Greenbrier river drainages. Meristic characters evaluated for the F1 hybrid were dorsal-fin spines, dorsal-fin rays, pectoral-fin rays, pelvic-fin rays, pelvic fin spines, anal-fin rays, anal-fin spines, scales above lateral line, scales below lateral line, scales along lateral line, circumpeduncle scales, dark lateral bars, and dorsolateral saddles, dorsal-fin saddle, embedded breast squamation, exposed breast squamation, opercle squamation, supraopercular squamation (Table 3). The F1 hybrid lateral line scale count range was above the mode for E. variatum and below the mode for E. osburni. All F1 hybrids possessed characters of both parental species. Photographs of individuals that express hybrid characters are shown in Figures 9 and 10. Photographs of E. osburni and E. variatum are given in Figures 11 through 14.

\section{Discussion}

The percentage of E. variatum alleles present at each site can be used to monitor changes in introgression rates over time. This metric can be used to estimate the intensity of genetic swamping experienced by E. osburni and monitor expansion of the hybrid swarm. Another method to observe development of the hybrid swarm is to delineate it by the presence of samples containing F1 hybrids and/or backcrosses with F1 hybrids. These samples could also conceivably contain both E. osburni and E. variatum parental species genotypes. Important sites in this study that produced these genotypes that can be used as current landmarks for the delineation of the hybrid swarm are Gauley River (Site 2), Knapp Creek (Site 16), and Deer Creek (Site 19). These three sites can be considered inflection points where the population of hybrids meets populations of E. osburni. While F1 hybrids were collected at Site 2, pure E. osburni were not collected here and so the true inflection point in the Gauley River probably lies slightly upstream of this site. Within the bounds of these landmarks, the populations and individuals are composed largely of $E$. variatum alleles. Beyond these landmarks, populations are characterized by members of E. osburni of pure descent and a few multi-generational backcrosses with E. osburni. 
Our data suggested a spread of the hybrid swarm over the time period of 2004 to 2014. E. variatum alleles were detected at the majority of the upstream-most sample sites in the Greenbrier River drainage such as Sitlington Creek (Site 18), West Fork Greenbrier River (Site 22), and Little River East Fork Greenbrier River (Site 21). E. variatum alleles were also found at the upstream-most sample site in the Gauley River drainage below Summersville Dam (Site 3). Switzer et al. (2007) found no evidence of hybridization in the Greenbrier River drainage upstream of Anthony Creek. The current study found a substantial presence of E. variatum alleles throughout the drainage upstream of Anthony Creek. The collection of F1 hybrids during this study indicates contemporary hybridization at these sites and the presence of an active hybrid zone. Switzer et al. (2007) found no evidence of hybridization in the Gauley River drainage above Summersville Dam but the current study detected E. variatum alleles at two sites in this area (Sites 4 and 9).

The hybrid swarm could spread naturally from a single introduced nucleus or could be facilitated by anthropogenic introductions of $E$. variatum alleles. There may be continual or many introductions of E. variatum (e. g. bait bucket, aquarium release). These introductions may be occurring repeatedly at the same location or sporadically throughout the drainage. Etheostoma variatum alleles may also be transported by human aided movement of hybrid individuals. It seems more likely, though, that the current state of the hybrid zone is a natural expansion of an established hybrid swarm.

Introgressive hybridization is one mechanism that facilitates the dispersal of invasive fish species (Hitt et al. 2003; Walters et al. 2008; Ward et al. 2012). Expansion, following introduction and establishment, is characteristic of some hybrid swarms (Kolar and Lodge 2001). Etheostoma osburni alleles were detected in the sample from Bells Creek where there are no records for E. osburni. The presence of E. osburni alleles in this sample suggests the possible natural dispersal of hybrid individuals to this area from a population of invaded E. osburni. A substantial quantity of visually identified $E$. variatum was collected in New River (Wellman et al. 2004). The presence of E. variatum and hybrids in the drainage, the thoroughness of genetic swamping of E. osburni by E. variatum within the hybrid zone, the presence of hybrids where E. osburni was previously absent, and the pattern of species alleles along a 
concentration continuum suggest a natural dispersion of the hybrid swarm in the Greenbrier River drainage. If dispersion of the hybrid swarm was to rely solely on widespread anthropogenic introductions, it may be expected to appear as many concentrated populations of hybrids or E. variatum rather than a single, dendritic continuum. This does not preclude the possibility of past, contemporary, or future E. variatum introductions simultaneous to natural dispersion and does not explain the presence of E. variatum alleles in the Gauley River drainage which were likely the product of additional and separate introduction events.

The fitness consequences of introgression between E. osburni and E. variatum are unknown. One possible consequence is outbreeding depression. This would occur when hybrid individuals exhibit lower fitness in the E. osburni range than the parental species. Another potential outcome is heterosis, or hybrid vigor, which is the production of hybrid offspring that exhibit fitness traits that are superior to those of the parental species. Given the widespread dispersal of hybrids in the New, Gauley, and Greenbrier river drainages, outbreeding depression is likely not the result of introgression. Etheostoma osburni is found in colder headwater streams than E. variatum. Cold headwater stream temperatures may favor E. osburni and decrease the rate of E. variatum introgression, however, it is not a complete barrier to E. variatum gene flow as evidenced by the discovery of $E$. variatum alleles in all of the headwater locations sampled in the Greenbrier River drainage.

The F1 hybrid phenotype exhibits a range of characters that overlaps with both parental species. All of the meristic character ranges of the F1 hybrid overlapped with ranges for E. osburni generated for a concurrent study as well as overlapping with published ranges for E. variatum (Page 1983; Page and Burr 2011). A notable character that aided in the identification of a hybrid was the presence of cephalic squamation. Although Page (1983) lists the opercular squamation as variable in E. osburni, this study found that it, in conjunction with squamation of the supraopercular region, was a useful character for distinguishing hybrids (Figure 4). F1 hybrid individuals were found to express combinations of characters of both parental species as well as express intermediacy within single characters. This was observed in meristics and pigmentation. 
There are limitations to using only microsatellite loci to detect hybridization. It is possible for a specimen to possess nuclear genotypes from one parental species but have mitochondrial haplotypes from another parental species (Wilson and Bernatchez 1998; Vilà et al. 2003; Switzer et al. 2007). Another study observed a greater range of introgression with non-neutral single nucleotide polymorphisms compared to neutral microsatellite loci (Fitzpatrick et al. 2009). A more sensitive approach to detecting introgression should include mitochondrial and non-neutral markers in addition to diagnostic microsatellite loci.

\section{Conclusions}

The detrimental effects of human-induced introductions of an invasive species are apparent in the results of this research. This study found strong evidence that E. osburni in the Greenbrier River drainage are threatened with genetic swamping by $E$. variatum. The influence of the hybrid swarm in this drainage is pervasive. Evidence of E. variatum introduction into the Gauley River drainage above Summersville Dam was detected in low concentrations; however, the presence of a hybrid swarm has yet to be observed in the upper drainage. A loss of the Greenbrier population of E. osburni would leave a substantial gap in the geographic range and genetic diversity of this species.

\section{Management Implications}

Non-native aquatic taxa are abundant and widespread in the upper Kanawha River system. Invasive species are one of the largest factors that reduce biodiversity and threaten native species (Vitousek et al. 1997). The prevention of further introductions should be a primary goal for aquatic conservation. Etheostoma variatum was most likely introduced to the New River drainage through one or many anglers' bait buckets. It is recommended that only a selected set of particular species should be listed and clearly posted as legal aquatic organisms allowed as bait for each body of water to reduce the potential for introductions. Advertisement in the form of signs and in fishing regulations that concisely explain that it is illegal to move all other species of aquatic organisms (e. g. fish, crayfish, etc.) should be 
considered. While a complete ban on using aquatic organisms for fishing bait is likely to be met with fierce resistance, it should be strongly considered as a management component to protect the Gauley population of E. osburni and in other waters where imperiled species of aquatic taxa occur. Future studies should monitor changes in the presence of E. variatum in the Gauley and Greenbrier river drainages. 


\section{Chapter 3: Comparison of Etheostoma osburni between the Gauley and Greenbrier river drainages}

\section{Introduction}

The Candy Darter (Etheostoma osburni; Hubbs and Trautman 1932) is a brilliantly colored species of darter in the perch family (Percidae: Etheostomatini). Etheostoma osburni is endemic to the upper Kanawha River system above Kanawha Falls. Its range includes the Gauley and Greenbrier rivers of West Virginia and the New River within West Virginia and Virginia (Jenkins and Burkhead 1994; Stauffer et al. 1995). Within West Virginia, it has been historically distributed throughout the Gauley River, the Greenbrier River, the Bluestone River, and Indian Creek of the New River drainage. This darter primarily occupies the rubble and boulder substrate of riffle habitat of small streams and midsize rivers (Chipps et al. 1994). Etheostoma osburni feeds opportunistically on benthic macroinvertebrates. Mayflies (Ephemeroptera) comprise the majority of their diet (Schoolcraft et al. 2007). Schoolcraft and Tarter (2002) estimated the peak spawning time of E. osburni in the South Fork of the Cherry River to be approximately April 21. Jenkins and Burkhead (1994) documented a significant reduction in the range of E. osburni in Virginia in recent history. Due to limited distribution and population reduction, E. osburni is listed as a Species of Concern in West Virginia, a Species of Special Concern in Virginia, and a Federal Species of Concern (USFWS 1989; Jelks et al. 2008).

Portions of the New, Gauley, and Greenbrier river drainages have been invaded by E. variatum, which is genetically swamping populations of E. osburni. Hybridization with introgression is one mechanism that can cause the extinction of native species (Rhymer and Simberloff 1996). This is occurring throughout the Gauley River (below Summersville Dam), New River (below Bluestone Dam), and Greenbrier River drainages. All of the populations of E. osburni within this distribution have become or are threatened with imminent genetic extinction. The populations in these drainages that have not disappeared due to habitat loss will most likely disappear due to introgression with E. variatum. Summersville and Bluestone Dams are the only barriers preventing the genetic extinction of E. osburni. 
A study by Switzer et al. (2007) found evidence of genetic divergence between the Gauley and Greenbrier populations of E. osburni. Switzer et al. (2007) stated that it appeared to be a longstanding allopatric fragmentation of the Gauley and Greenbrier populations that resulted in relatively high levels of differentiation. They also stated that the two populations appear to have experienced different demographic events such as a bottleneck followed by range expansion in the Gauley population. This is in contrast to the Greenbrier River drainage with an apparent larger population of E. osburni and greater stability over time (Switzer et al. 2007). Due to genetic differences between populations, a loss of one population would result in the loss of genetic diversity for the species as a whole.

Gene diversity between geographic clusters is generally greater than between localities within clusters (Gyllensten 1985). Species that inhabit headwater stream habitat may have high levels of genetic divergence at small spatial scales (Turner and Robison 2006). Another species of darter, the Ashy Darter (Etheostoma cinereum) has a fragmented range, the fragmented populations have genetically diverged, and three populations showed morphologic variation that supported the recognition of distinct management units (Powers et al. 2004). The Cumberland River population of E. cinereum has been described as E. maydeni (Powers et al. 2012).

This chapter identifies genetic and morphometric differences between the populations of $E$. osburni in West Virginia. The objectives of this study were to evaluate E. osburni of the Gauley and Greenbrier river drainages to 1) estimate the number of distinct populations (K) of E. osburni in West Virginia and measure genetic differentiation $\left(\mathrm{F}_{\mathrm{ST}}\right)$ among the populations, and 2) evaluate these populations with morphometric techniques to identify morphological differences.

\section{Materials and Methods}

\section{Collection and Preservation}

Tissue samples and potential morphometric specimens $(n=335)$ were collected from 22 locations (Table 1). A total of 45 locations were visited for this study. Sites that did not produce specimens are listed in Table 2. A field technician was outfitted with a backpack electrofishing unit and two forward- 
facing wands to shock in a downstream fashion towards a seine net (5 ft x $10 \mathrm{ft} \times 3 / 16$ in; $1.24 \mathrm{~m} \times 3.05$ $\mathrm{m} \times 4.76 \mathrm{~mm})$. The seine net was placed approximately $5 \mathrm{~m}$ below the technician. Two additional field technicians flanked the electrofisher to disrupt the substrate. A series of intertransects that were parallel to the direction of the stream current were followed until nearly full coverage of the riffle habitat for that reach was attained or a minimum of 30 individuals was obtained, whichever occurred first. Multiple riffles in some extended reaches were sampled to increase sample size when E. osburni was sparse.

A tissue sample was taken from the right pelvic fin from each individual for genetic analysis. Fin clips were placed in $99 \%$ ethyl alcohol, and then the entire fish was placed in $10 \%$ formalin. Labels for each specimen were created to identify individuals and to link genetic data to morphometric specimens. The formalin was discarded after at least six months and replaced with water. The water was replaced with fresh water once per day for four consecutive days after which the containers were filled with $45 \%$ isopropyl alcohol.

Morphometric data were recorded from adult males. The minimum standard length was 57.8 $\mathrm{mm}$. Etheostoma osburni is sexually dimorphic and so it was important to compare measurements within a particular sex. Sex was determined by examining genital papillae and supported by male nuptial characters such as thickened fins, enlarged scale margins, and concentrations of pigment. In addition to restricting morphometric data collection to adult males, it was important to verify that specimens were of pure E. osburni ancestry due to the presence of potential introgression with an expanding hybrid swarm.

\section{Genetic Characterization}

Switzer et al. (2008) developed a set of 15 polymorphic microsatellite DNA markers for examining genetic variation within populations and potential hybridization between E. osburni and E. variatum. Five of these microsatellite loci (Eos-C2, Eos-C3, Eos-C6, Eos-C112, and Eos-C117) were found to be diagnostic in the differentiation between the two species. This set of diagnostic loci was instrumental in detecting hybridization and verifying the purity of species of individuals. Primers for these loci were manufactured by and obtained from Integrated DNA Technologies. Data collected for these five diagnostic loci for a concurrent study of hybridization was used for evaluating the population 
structure of E. osburni in this study. The purity and admixture of each specimen was manually verified by examining the five diagnostic loci. Individuals that possessed $E$. variatum alleles in any quantity at the diagnostic loci were excluded from genetic and morphometric analytical comparison between populations of E. osburni.

Total genomic DNA was extracted with the Promega SV 96 Genomic DNA Purification System following a modified version of the "Animal Tissues" protocol (Promega Technical Bulletin Part \#TB303). Approximately $4 \mu \mathrm{g}( \pm 2 \mu \mathrm{g}$; or approximately $1 \mathrm{~mm} \mathrm{X} 2 \mathrm{~mm})$ of pelvic fin tissue per specimen was prepared in each well of a 96 -well plate for a 16 hour digestion at $55^{\circ} \mathrm{C}$. The elution process consisted of two $50 \mu \mathrm{L}$ elutions (for a total elution volume of $100 \mu \mathrm{L}$ ) and was performed with a combination of vacuum and centrifugation. Concentrations of extracted DNA were quantified with a NanoDrop Lite spectrophotometer. A dilution $(10 \mathrm{ng} / \mu \mathrm{L})$ of each extraction product was created and amplified using the polymerase chain reaction (PCR).

Five microsatellite loci were amplified (Eos-C2, Eos-C3, Eos-C6, Eos-C112, and Eos-C117; Switzer et al. 2008). Conditions of microsatellite PCR consisted of $20 \mathrm{ng}$ of genomic DNA, $0.4 \mathrm{X}$ QIAGEN Multiplex PCR master Mix, and $0.2 \mu \mathrm{M}$ of each primer (with the forward primer fluorescently labeled) in a 10- $\mu$ l final reaction volume. A C1000 Touch (BioRad) thermal cycler was used to conduct the PCR reaction that consisted of an initial denaturation at $95{ }^{\circ} \mathrm{C}$ for $15 \mathrm{~min} ; 25$ cycles of $94{ }^{\circ} \mathrm{C}$ denaturation for $30 \mathrm{~s}, 57^{\circ} \mathrm{C}$ annealing for $90 \mathrm{~s}, 72{ }^{\circ} \mathrm{C}$ extension for $60 \mathrm{~s}$; and a $60{ }^{\circ} \mathrm{C}$ final extension for $30 \mathrm{~min}$.

Capillary electrophoresis of PCR product ( $2 \mu \mathrm{L}$ per reaction) was conducted on a GenomeLab GeXP Genetic Analysis System (Beckman Coulter) with 400 bp size standard (0.5 $\mu$ L per reaction) and sample loading solution (27.5 $\mu \mathrm{L}$ per reaction). The associated software, GenomeLab GeXP Series Software Suite, was used to visualize analyzed fragments and manually score alleles to generate genotype data for each individual. ALLELOGRAM v2.2 (Manaster 2009) was used to normalize and bin alleles utilizing a positive control common to all capillary electrophoresis runs. 
Error of laboratory practices was evaluated. Ten percent of the tissue samples were selected with a random number generator. Each of these samples was extracted, amplified, visualized, and scored again according to the aforementioned practices. These data were compared to those of the original series to identify inconsistencies between allele scoring. Error rates were summarized as the number of inconsistently scored alleles divided by the total number of alleles.

Error of allele scoring was evaluated. A random number generator was used to select 47 (14\%) of the original capillary electrophoresis results. The corresponding electropherograms were cross-read by another researcher to independently score alleles. These data were compared to the original data to identify inconsistencies between allele scoring. A discrepancy between original and independently scored alleles was interpreted as potential error and summed. Error rates were summarized as the number of inconsistently scored alleles divided by the total number of alleles.

The potential for null alleles was investigated with MICROCHECKER v2.2.3 (Van Oosterhout et al. 2003). Default settings were used with a maximum expected allele size of $500 \mathrm{bp}$, a $95 \%$ confidence interval, and 1000 randomizations. Each population identified during the STRUCTURE analysis was investigated independently. The software GENEPOP v4.2 (Raymond and Rousset 1995) was used to determine the status of Hardy-Weinberg equilibrium (HWE) of populations defined during the STRUCTURE analysis and of the 10 samples defined in Table 4 that comprise the Gauley and Greenbrier populations. A probability test for each locus in the population or sample was conducted to estimate exact P-values with the Markov chain method. The following Markov chain parameters were used: Dememorization number $=1000 ; 100$ batches; and 1000 iterations per batch. The significance level was set at $\alpha=0.05$.

The number of independently operating genetic clusters or populations $(\mathrm{K})$ was inferred with STRUCTURE v2.3.4 (Pritchard et al. 2000). The initial analysis was conducted on the entire microsatellite data set representing 335 individuals. Ten independent runs for each $\mathrm{K}$ from $\mathrm{K}=1$ to $\mathrm{K}=$ 13 with 100,000 Markov Chain Monte Carlo (MCMC) iterations and a burn-in period of 100,000 generations were performed. The default settings which included correlated allele frequencies, assumed 
admixture, and no prior information were used. STRUCTURE HARVESTER v0.6.94 was used to visualize the STRUCTURE results and implement the $\Delta \mathrm{K}$ method of Evanno et al. (2005) to determine the number of $\mathrm{K}$ at the highest level of genetic partitioning (Earl and vonHoldt 2012). A recursive, hierarchical approach to investigate substructure, or deeper delineation of populations, was implemented. A subsequent STRUCTURE analysis with 10 independent runs for each $K$ from $K=1$ to $K=12$ with 100,000 Markov Chain Monte Carlo (MCMC) iterations and a burn-in period of 100,000 generations was conducted on the E. osburni cluster. Each subsequently identified population was investigated in the same fashion.

To measure genetic differentiation, pairwise tests of fixation index $\left(\mathrm{F}_{\mathrm{ST}}\right)$ among sample locations and between the Gauley and Greenbrier populations were conducted with FSTAT v2.9.3.2 (Goudet 2002). The indicative adjusted nominal level for multiple comparisons was set at $\alpha=0.05$. An analysis of genetic distance was performed with the PHYLIP v3.695 software package (Felsenstein 2009). Individuals $(\mathrm{n}=211)$ of pure E. osburni from 16 sites were used for this analysis (Table 4). Some of these sites yielded low $(\mathrm{n}<10)$ numbers of pure E. osburni and were therefore combined with geographically adjacent sites to create larger sample sizes for a total of 10 samples in this analysis as described in Table 4. One thousand replicated samples were generated and a neighbor-joining tree was constructed based on the Cavalli-Sforza chord measure (Cavalli-Sforza and Edwards 1967).

To measure genetic diversity, private alleles in the Gauley and Greenbrier populations were identified with GENEPOP v4.2 (Raymond and Rousset 1995). The proportion of polymorphic loci in the two populations was calculated. FSTAT v2.9.3.2 (Goudet 2002) was used to calculate allelic richness per locus. Observed and expected heterozygosities for each locus of each population were calculated with ARLEQUIN v3.5.2.2 (Excoffier and Lischer 2010). Differences of observed heterozygosity and allelic richness between populations were normally distributed as determined with a Shapiro-Wilk test. A paired t-test was used to test significance of difference between the Gauley and Greenbrier populations for observed heterozygosity and allelic richness per locus. 


\section{Morphometrics}

Morphometric and meristic data were taken from 41 adult male individuals of pure E. osburni descent. These fish were collected from 12 sites in the Gauley $\left(n_{\text {specimens }}=16 ; n_{\text {sites }}=5\right)$ and Greenbrier $\left(\mathrm{n}_{\text {specimens }}=25 ; \mathrm{n}_{\text {sites }}=5\right)$ river drainages. These metrics are enumerated and described in Tables 5 and 6 . The box truss network system, modified from Strauss and Bookstein (1982) in the style of Welsh and Wood (2008), was used to produce morphometric data. A series of 11 midsagittal landmarks was selected and 23 distances were measured between the landmarks to create a box truss network (Figure 15). Seven distances that characterize head geometry (including gape and eye width) were measured. Three additional distances (standard length, outerpelvic width, and caudal fin length) were taken for a total of 33 straight-line (point to point) distances measured for each individual (Figure 16). Digital calipers were used to measure distances and record values to the hundredth of a millimeter. Data for 14 meristic variables were recorded: dorsal-fin spines, dorsal-fin rays, pectoral-fin rays, pelvic-fin rays, pelvic-fin spines, anal-fin rays, anal-fin spines, scales above lateral line, scales below lateral line, scales along lateral line (left), scales along lateral line (right), circumpeduncle scales, dark lateral bars, and dorsolateral saddles. Presence-absence data were recorded for five variables: dorsal-fin saddle, breast squamation (embedded), breast squamation (exposed), opercle squamation, and supraopercular squamation. The dorsolateral saddle that occurs beneath the first dorsal fin was counted separate from the other saddles. Supraopercular squamation may occur in the dorsolateral region of the head above the opercle. The minimum, maximum, and mode values for meristic variables are reported. Sheared principal components analysis (SPCA) was used to analyze morphometric data. SPCA was implemented with SAS code (D. Swofford, Statistical Analysis Systems Institute, Inc., Carry, NC; SAS Institute 1990). Error of measured

morphometric distances was assessed. Morphometric evaluation of a single individual was repeated 20 times. This series of measurements was taken according to the aforementioned practices to produce a separate set of data. Error of morphometric data is reported as variance within each variable. 


\section{Results}

\section{Genetic Characterization}

Ten percent of the original tissue samples were randomly selected and extracted, amplified, visualized, and scored again for comparison to original scores. The validation process yielded results that were identical to the corresponding original data; therefore, an error rate of zero was attributed to laboratory practices.

Fourteen percent (47 of the total 335) of the electropherograms were cross-read for error quantification of allele scoring. Of these data, 6 of $470(0.013)$ alleles were scored differently by an independent researcher. These differences represented four alleles at two loci in three individuals. By locus, there were no allelic discrepancies found at Eos-C2, Eos-C3, and Eos-C6; Eos-C6 yielded an error rate of 0.021; and Eos 117 yielded an error rate of 0.043. At this error rate, we would expect approximately 43 possible allelic discrepancies within the total of 3350 alleles. None of these discrepancies resulted in scoring alleles that would misassign an individual to species or hybrid class nor did any of the discrepancies result in novel alleles for that sample. This error rate was considered to be acceptable.

The MICROCHECKER analysis found no evidence for scoring error due to stuttering, no evidence for large allele dropout, and no evidence of null alleles at any of the loci in the Gauley and Greenbrier populations. All loci in the Gauley and Greenbrier populations of E. osburni were in HWE (Tables 7 and 8). The Gauley population, including each sample that comprises this population, is fixed for a single allele at Eos-C3. Each sample that comprised the Gauley and Greenbrier populations was in HWE.

A total of 335 individuals from the Gauley and Greenbrier river drainages were genotyped. Of this total, 124 genotypes included alleles within the size range of E. variatum and, therefore, were excluded from analysis of or comparison between populations of E. osburni. This resulted in sample sizes of 144 and 67 for the Gauley and Greenbrier populations of E. osburni, respectively. 
A STRUCTURE analysis that included individuals assigned to the initial population of E. osburni identified in Chapter 2 revealed substructuring within this species (Figure 6). It was found that $\mathrm{K}=2$ within E. osburni, which represented a distinction between the two populations of the Gauley and Greenbrier river drainages. No additional substructuring was found within these two populations of $E$. osburni.

The Gauley and Greenbrier populations of E. osburni were highly differentiated. Differentiation between the two populations was calculated as $\mathrm{F}_{\mathrm{ST}}=0.144(\mathrm{P}=0.017)$. A pairwise calculation of $\mathrm{F}_{\mathrm{ST}}$ among the 10 samples described in Table 4 resulted in $-0.011 \geq \mathrm{F}_{\mathrm{ST}} \geq 0.205$ (Table 9). The largest value $\left(\mathrm{F}_{\mathrm{ST}}=0.205\right)$ was observed between Upper Gauley River and Mid-Greenbrier River. All pairwise calculations of $\mathrm{F}_{\mathrm{ST}}$ among samples between the Gauley and Greenbrier river drainages were significant at the indicative adjusted nominal level $(5 \%)$ for multiple comparisons $(\mathrm{P}=0.001)$. One calculation of $\mathrm{F}_{\mathrm{ST}}$ among samples within the Gauley River drainage was significant at this level; this was between Upper Gauley River and Laurel Creek.

Another method to observe genetic differences between the two populations of E. osburni is through the construction of a neighbor-joining tree. As seen in Figure 17, all samples within each of the Gauley and Greenbrier populations group together in $98.5 \%$ of 1000 generated trees. This demonstrates a marked distinction between the two populations. With one exception noted below, there were levels of consensus greater than $50 \%(52.1 \%-91.2 \%)$ for all of the within drainage positions of the tree. The Upper and Lower Gauley river samples were indicated as neighbors in $46.4 \%$ of 1000 generated trees.

A summary of allelic diversity, frequency, and variation per locus for each population is given in Tables 10 and 11. The number of alleles per locus ranged from $1-7$ in the Gauley population and $2-10$ in the Greenbrier population. There were a total of 18 alleles across all loci in the Gauley population, 29 in the Greenbrier population, and an overall total of 30. The number of private alleles was 1 in the Gauley population and 12 in the Greenbrier population. The proportion of polymorphic loci was 0.8 in the Gauley population and 1.0 in the Greenbrier population. Observed heterozygosity $\left(\mathrm{H}_{\mathrm{o}}\right)$ and expected heterozygosity $\left(\mathrm{H}_{\mathrm{e}}\right)$ mean values for all loci in the Gauley population were 0.557 and 0.552 , respectively. 
$H_{o}$ and $H_{e}$ mean values for all loci in the Greenbrier population were 0.442 and 0.436 , respectively. $H_{o}$ did not differ significantly between populations $(\mathrm{P}=0.973)$. Average allelic richness was 3.324 and 5.800 for the Gauley and Greenbrier populations, respectively, and did not differ significantly between populations but approaches significance $(\mathrm{P}=0.059)$. This lack of significance may be due to a low number $(n=5)$ of loci used.

\section{Morphometric Characterization}

Error of measured morphometric distances was assessed with a series of measurements that was repeated 20 times for a single individual. A summary of these measurements and associated variances are reported in Table 12. The overall minimum, maximum, and mean variance was $0.01 \mathrm{~mm}, 0.29 \mathrm{~mm}$, and $0.08 \mathrm{~mm}$, respectively. The minimum variance was obtained with depth at caudal flexure, eye width, anterior internasal width, posterior internasal width, interorbital width, gape width, and outerpelvic base width, equivalently as 0.01 . The maximum variance was obtained with caudal-fin length. This level of error was considered acceptable.

The Greenbrier population had greater morphometric ranges in 18 of 32 distance variables measured. As such, the Gauley population morphometry was a subset of that of the Greenbrier population for these variables. The Gauley population portrayed higher maximum values for 13 of the other variables and a lower minimum for 1 . The Gauley population exhibited a wider range of values than the Greenbrier population for only one variable. This general wider range of morphometric values for the Greenbrier population may be an artifact of a larger sample size. All of the ranges for all of the characters show overlap. Nonetheless, plots of SPC2 by SPC3 show considerable separation along the SPC2 axis, although, without complete separation.

Plots of the sheared second and third principal components (SPC2 and SPC3) depict shape differences between the Gauley and Greenbrier populations of E. osburni (Figure 18). Interorbital width (0.78), followed by snout-branchiostegal connection (-0.26), loaded highest on the SPC2 axis. Snoutbranchiostegal connection (0.42), branchiostegal connection-midpoint between pelvic-fin bases (0.30), snout-anterior margin of eye (0.26), occiput-first dorsal-fin spine (-0.46), base of anal fin $(-0.27)$, and 
first anal-fin ray-last dorsal-fin ray (-0.24) loaded highest on the SPC3 axis. $21.9 \%$ and $18.4 \%$ of the variation was explained along the SPC2 and SPC3 axis, respectively. Morphometric distances that were used in SPCA of the Gauley and Greenbrier populations of E. osburni were summarized (Table 5).

The meristics for all variable ranges overlapped between the Gauley and Greenbrier drainages. While there was not complete separation of ranges for any of the variables, many differed modally (Table 6). The number of pectoral fin rays, anal fin rays, scales below the lateral line, scales along the lateral line, and scales around the caudal peduncle differed, modally, between populations. One of the largest meristic differences between populations was that of embedded breast squamation. The Greenbrier population had a $64 \%$ rate of individuals that possessed embedded breast squamation compared to 12.5 $\%$ of the Gauley population. Furthermore, Greenbrier population members that exhibited embedded breast squamation typically possessed larger numbers of scales compared to those of the Gauley population. The means of all standard meristic variables (i. e. non-presence/absence variables) differed between populations by less than one standard deviation.

Typically, when the dorsolateral saddle count was 4 , rather than 5 , it was because the caudal peduncle saddles were partially or entirely joined. The dorsal-fin saddle was not always readily distinguishable. At times it was obscured by dark background pigment and at other times it may have been faded in a fixed specimen but, perhaps, visible in a live specimen. The variability of these two characters (dorsal-fin saddle and caudal peduncle saddle) is why they are considered to be a separate meristic in this study. Excluding the variability of the dorsal-fin saddle allowed for a more meaningful overall meristic for the other dorsolateral saddles.

\section{Discussion}

This study found that the Gauley and Greenbrier populations are highly differentiated with a fixation index of $\mathrm{F}_{\mathrm{ST}}=0.144(\mathrm{P}=0.017)$. Values of $\mathrm{F}_{\mathrm{ST}}$ range from 0.0 to 1.0 . A value of $\mathrm{F}_{\mathrm{ST}}=0.05$ is considered to be moderately differentiated and a value of $\mathrm{F}_{\mathrm{ST}}=0.15$ is considered to be highly 
differentiated. All of the pairwise comparisons of samples between the Gauley and Greenbrier populations yielded significant $\mathrm{F}_{\mathrm{ST}}$ values which ranged from $0.103-0.205(\mathrm{P}=0.001)$. With one exception, all of the comparisons of samples within populations yielded non-significant $\mathrm{F}_{\mathrm{ST}}$ values. Switzer et al. (2007) also found that the Gauley and Greenbrier populations were significantly differentiated when compared with AMOVA using F-statistics, R-statistics, and $\Phi$-statistics. Different demographic events, different results of genetic drift, and mutations that are not shared between populations affect allelic frequencies of these populations independently. In recognition of these $\mathrm{F}_{\mathrm{ST}}$ values, the Gauley and Greenbrier populations of E. osburni appear to have experienced long-term allopatric separation.

Most of the comparisons between samples within populations resulted in low values of $\mathrm{F}_{\mathrm{ST}}$. Two comparisons yielded extremely low values. An index of $F_{S T}=-0.005$, interpreted as $F_{S T}=0$, between Lower Gauley River and South Fork Cherry River implies complete panmixia. While this may have been the case historically, Summersville Dam is a major geographical barrier that prevents random mating between these two clusters of fish. For the same reason, an equivalently obscure index of $F_{S T}=0.000$ was obtained with a comparison between Lower Gauley River and North Fork Cherry River. Relatively new geographical barriers such as dams can cause genetic divergence in fish, including rapid speciation in darters, between separated populations (Near and Benard 2004; Roberts et al. 2013). Summersville Dam, however, seems to have had little influence on differentiation compared to historical events. The low $\mathrm{F}_{\mathrm{ST}}$ values for above and below Summersville Dam within the Gauley River drainage imply that the genetic differentiation between the Gauley and Greenbrier populations of E. osburni are due to reasons, such as natural divergence, other than the dam.

This study and a prior study (Switzer et al. 2007) have found strong evidence of the existence of Distinct Population Segments (DPS). There are two criteria for designation as a DPS: 1) discreteness; and 2) significance. The populations are discrete as evidenced by high genetic differentiation. There was a presence of a high number of private alleles in the Greenbrier population found in this study and a high rate of private alleles in both populations found by Switzer et al. (2007) using the full set of microsatellite 
loci. There were high $\mathrm{F}_{\mathrm{ST}}$ indices among all pairwise comparisons of samples between the drainages. Furthermore, the two populations are discrete because they are physically separated by distance. Switzer et al. (2007) discussed how the Gauley and Greenbrier populations are separated by over $600 \mathrm{~km}$ of river distance, have a long standing history of separation, and have experienced different demographic events. That study postulated that the Greenbrier population has maintained a consistently larger population over time compared to a possible bottleneck that the Gauley population may have experienced. Hence, the two populations have 1) discreteness due to both marked genetic and physical separation. The two populations have significance because 2) the loss of any extant population, including either the Gauley or Greenbrier population, of E. osburni would result in a significant gap in the range of this species. In addition, the Gauley and Greenbrier populations differ markedly in genetic characteristics. For these two reasons, the two populations meet the significance criterion. A concurrent study found that a hybrid swarm is in the active process of expansion in the Greenbrier River drainage (detailed in Chapter 2). This is causing a rapid loss of E. osburni in this drainage and will probably result in a complete loss of this population. Evidence of a low level of hybridization was also found in the Gauley population but a hybrid swarm was not detected. This population will face the same threat if E. variatum is successfully established in the Gauley River drainage. The imperiled status of these populations and this species as a whole would likely fulfill the status requirement for listing of the DPS as endangered or threatened. Although this study did not investigate E. osburni of Virginia, the same components of discreteness, significance, and status likely apply when including this cluster of E. osburni. Each population of $E$. osburni merits strong consideration for designation as a DPS.

This study was performed in tandem with another study that investigated the current geographic extent of an expanding hybrid swarm and, therefore, used the same genotype data set that was generated for that study. That study focused on identifying hybrid individuals with five diagnostic loci. Switzer et al. (2008) identified and evaluated 14 microsatellite loci for E. osburni which included 9 loci in addition to the diagnostic loci used for this study. The scope of the results and conclusions of this study are within the context of this suite of five diagnostic loci. 


\section{Conclusions}

The Greenbrier and Gauley populations of E. osburni are genetically distinct. They are reproductively operating as separate populations and exhibit characteristic allelic diversities. They have a high level of population differentiation. These two populations exhibit a large quantity of morphometric overlap but have subtle differences in character ranges. The two populations appear to be in the process of speciation but is early in their independent trajectories

\section{Management Implications}

Regulations should be considered for reducing further introductions of E. variatum to the Gauley River drainage, as suggested in Chapter 2. Genetic diversity between the Gauley, Greenbrier, and Virginia populations of E. osburni can be investigated with the 9 additional microsatellite loci that were identified by Switzer et al. (2008) for a total of 14 loci. If it is determined that the Greenbrier and Virginia populations of E. osburni are not substantially differentiated, then pure E. osburni individuals from the Greenbrier population could be used in a reintroduction program to rescue this lineage. Former E. osburni range such as Bluestone River and Indian Creek drainages of West Virginia are reintroduction location options. Bluestone Dam may limit dispersal of E. variatum into this system. If the Greenbrier and Virginia populations are substantially differentiated, then risk evaluation may be prudent as introgression between these two populations of E. osburni may create further conservation concerns. The Gauley, Greenbrier, and Virginia populations of E. osburni should be considered for designation as Distinct Population Segments (DPS). Etheostoma osburni should be considered for listing as endangered under the U.S. Endangered Species Act. Furthermore, the biodiversity of West Virginia may benefit from the existence of a State Endangered Species Act for more effective conservation of native imperiled species. 


\section{LITERATURE CITED}

Almodóvar, A., G. G. Nicola, S. Leal, M. Torralva, and B. Elvira. 2012. Natural hybridization with invasive bleak Alburnus alburnus threatens the survival of Iberian endemic calandino Squalius alburnoides complex and Southern Iberian chub Squalius pyrenaicus. Biological Invasions. 14.11:2237-2242.

Anderson, E.C., and E. A. Thompson. 2002. A model-based method for identifying species hybrids using multilocus genetic data. Genetics 160:1217-1229.

Angermeier, P. L. 1995. Ecological attributes of extinction-prone species: loss of freshwater fishes of Virginia. Conservation Biology. 9.1:143-158.

Angermeier, P. L., and M. J. Pinder. 2015. Viewing the status of Virginia's Environment through the lens of freshwater fishes. Virginia Journal of Science. 66.3:2.

Avise, J.C. 2004. Molecular Markers, Natural History, and Evolution (Second Edition). Sinauer, Sunderland, MA. 684 pp.

Burns, A. D. 2007. Comparison of two electrofishing gears (backpack and parallel wires) and abundances of fishes of the upper Greenbrier River drainage. MS Thesis, West Virginia University, Morgantown, WV.

Cavalli-Sforza, L. L., and A. W. Edwards. 1967. Phylogenetic analysis. Models and estimation procedures. American journal of human genetics, 19.3.1:233.

Chipps, S. R., W. B. Perry, and S. A. Perry. 1994. Patterns of microhabitat use among four species of darters in three Appalachian streams. American Midland Naturalist. 131:175-180.

Cincotta, D. A., D. B. Chambers, and T. Messinger. 1999. Recent changes in the distribution of fish species in the New River basin in West Virginia and Virginia. Proceedings of the New River Symposium 98-106.

Della Croce, P., G. C. Poole, R. A. Payn, and R. E. Gresswell. 2017. Early Detection of Nonnative Alleles in Fish Populations: When Sample Size Actually Matters. Fisheries. 42.1:44-56.

Dunn, C. G., and P. L. Angermeier. 2016. Development of Habitat Suitability Indices for the Candy Darter, with Cross-Scale Validation across Representative Populations. Transactions of the American Fisheries Society. 145.6:1266-1281.

Earl, D. A., and B. M. vonHoldt. 2012. STRUCTURE HARVESTER: a website and program for visualizing STRUCTURE output and implementing the Evanno method. Conservation Genetics Resources. 4.2:359-361.

Evanno, G., S. Regnaut, and J. Goudet. 2005. Detecting the number of clusters of individuals using the software STRUCTURE: a simulation study. Molecular Ecology. 14.8:2611-2620

Excoffier, L., and H. E. L. Lischer. 2010. Arlequin suite ver 3.5: A new series of programs to perform population genetics analyses under Linux and Windows. Molecular Ecology Resources. 10:564567. 
Felsenstein, J. 2009. PHYLIP (Phylogeny Inference Package) version 3.7a. Distributed by the author. Department of Genome Sciences, University of Washington, Seattle.

Fitzpatrick, B. M., J. R. Johnson, D. K. Kump, H. B. Shaffer, J. J. Smith, and S. R. Voss. 2009. Rapid fixation of non-native alleles revealed by genome-wide SNP analysis of hybrid tiger salamanders. BMC Evolutionary Biology. 9.1:176.

Gyllensten, U. 1985. The genetic structure of fish: differences in the intraspecific distribution of biochemical genetic variation between marine, anadromous, and freshwater species. Journal of Fish Biology. 26.6:691-699.

Goudet, J. 2002. FSTAT version 2.9. 3.2, a program to estimate and test gene diversities and fixation indices. Institute of Ecology, Lausanne, Switzerland. http://www2.unil.ch/popgen/softwares/fstat htm

Halas, D., and A. M. Simons. 2014. Cryptic speciation reversal in the Etheostoma zonale (Teleostei: Percidae) species group, with an examination of the effect of recombination and introgression on species tree inference. Molecular phylogenetics and evolution. 70:13-28.

Harrison, R. G., and E. L. Larson. 2014. Hybridization, introgression, and the nature of species boundaries. Journal of Heredity. 105.S1:795-809.

Hitt, N. P., C. A. Frissell, C. C. Muhlfeld, and F. W. Allendorf. 2003. Spread of hybridization between native westslope cutthroat trout, Oncorhynchus clarki lewisi, and nonnative rainbow trout, Oncorhynchus mykiss. Canadian Journal of Fisheries and Aquatic Sciences. 60.12:1440-1451.

Hocutt, C. H., and E. O. Wiley. 1986. The zoogeography of North American freshwater fishes. Hoboken, New Jersey.

Hubbs, C. L., and J. D. Black. 1940. Percid fishes related to Poecilichthys variatus, with descriptions of three new forms. Occasional Papers Museum of Zoology, University of Michigan. Number 416.

Jelks, H. L., S. J. Walsh, N. M. Burkhead, S. Contreras-Balderas, E. Diaz-Pardo, D. A. Hendrickson, J. Lyons, N. E. Mandrak, F. McCormick, J. S. Nelson, S. P. Platania, B. A. Porter, C. B. Renaud, J. J. Schmitter-Soto, E. B. Taylor, and M. L. Warren Jr. 2008. Conservation status of imperiled North American freshwater and diadromous fishes. Fisheries. 33.8:372-407.

Jenkins, R. E., and N. M. Burkhead. 1994. Freshwater fishes of Virginia. American Fisheries Society, Bethesda, Maryland.

Kirtland, J. P. 1840. Descriptions of four new species of fishes. Boston Journal of Natural History. 3:273277.

Kolar, C. S., and D. M. Lodge. 2001. Progress in invasion biology: predicting invaders. Trends in ecology \& evolution. 16.4:199-204.

Leftwich, K. N., C. A. Dolloff, and M. Hudy. 1994. Habitat and abundance of candy darters Etheostoma osburni in Stony Creek, Virginia: preliminary survey, September 1994. Final Report. USDA Forest Service, Southestern Experiment Station, Department of Fisheries and Wildlife, Virginia Tech, Blacksburg, VA. 9pp. 
Leftwich, K. N., C. A. Dolloff, and M. K. Underwood. 1996. The Candy Darter (Etheostoma osburni) in Stony Creek, George Washington - Jefferson National Forest, Virginia - Trout Predation, Distribution, and Habitat Associations. USDA Forest Service, Center for Aquatic Technology Transfer, Virginia Polytechnic Institute and State University, Blacksburg, VA.

Lintermans, M. 2004. Human-assisted dispersal of alien freshwater fish in Australia, New Zealand Journal of Marine and Freshwater Research. 38.3:481-501.

Litvak, M. K., and N. E. Mandrak. 1993. Ecology of freshwater baitfish use in Canada and the United States. Fisheries 18.12:6-13.

Loughman, Z. J., and S. A. Welsh. 2010. Distribution and conservation standing of West Virginia crayfishes. Southeastern Naturalist. 9.3:63-78.

Ludwig Jr., H. R., and J. A. Leitch. 1996. Interbasin transfer of aquatic biota via anglers' bait buckets. Fisheries 21.7:14-18.

Manaster, C. J. 2009. ALLELOGRAM v2.2: A program for normalizing and binning microsatellite genotypes. http://code.google.com/p/allelogram/.

Matthews, W. J., T. F. Turner, and M. J. Osborne. 2016. Breakdown of a Hybrid Swarm between Two Darters (Percidae), Etheostoma radiosum and Etheostoma spectabile, with Loss of One Parental Species. Copeia. 104.4:873-878.

May, B. 1969. Observations on the biology of the Variegated Darter, Etheostoma variatum (Kirtland). The Ohio Journal of Science. 69:85-92.

Muhlfeld, C. C., S. T. Kalinowski, T. E. McMahon, M. L. Taper, S. Painter, R. F. Leary, and F. W. Allendorf. 2009. Hybridization rapidly reduces fitness of a native trout in the wild. Biology Letters. 5:328-331.

Near, T. J., and M. F. Benard. 2004. Rapid allopatric speciation in logperch darters (Percidae: Percina). Evolution. 58.12:2798-2808.

Page, L. M. 1983. Handbook of darters. T.F.H. Publications, Neptune City, New Jersey.

Page, L. M., and B. M. Burr. 2011. Peterson field guide to freshwater fishes of North America north of Mexico. Houghton Mifflin Harcourt, Boston, Massachusetts.

Powers, S. L., R. L. Mayden, and D. A. Etnier. 2004. Conservation genetics of the Ashy Darter, Etheostoma cinereum (Percidae: subgenus Allohistium), in the Cumberland and Tennessee Rivers of the southeastern United States. Copeia. 2004.3:632-637.

Powers, S. L., B. R. Kuhajda, and S. E. Ahlbrand. 2012. Systematics of the Etheostoma cinereum. (Teleostei: Percidae) species complex (subgenus Allohistium). Zootaxa. 3277.1:43-55

Pritchard, J. K., M. Stephens, and P. Donnelly. 2000. Inference of population structure using multilocus genotype data. Genetics. 155:945-959.

Rahel, F. J. 2007. Biogeographic barriers, connectivity and homogenization of freshwater faunas: it's a small world after all. Freshwater Biology. 52.4:696-710. 
Raney, E. C. 1941. Poecilichthys kanawhae, a new darter from the upper New River system in North Carolina and Virginia. Occasional Papers of the Museum of Zoology, University of Michigan. Number 434.

Raymond, M., and F. Rousset. 1995. GENEPOP (version 1.2): population genetics software for exact tests and ecumenicism. J. Heredity. 86:248-249

Roberts, J. H., P. L. Angermeier, and E. M. Hallerman. 2013. Distance, dams and drift: what structures populations of an endangered, benthic stream fish?. Freshwater Biology. 58.10:2050-2064.

Rhymer, J. M., and D. Simberloff. 1996. Extinction by hybridization and introgression. Annual Review of Ecology and Systematics. 27:83-109.

SAS Institute. 1990. SAS/STAT user's guide: volume 2. SAS Institute, Cary, North Carolina.

Schoolcraft, A. E., and D. C. Tarter. 2002. Reproductive biology of the Candy Darter, Etheostoma osburni (Hubbs and Trautman), in the Cherry River, West Virginia. Proceedings of the West Virginia Academy of Science. 74:1.

Schoolcraft, A. E., D. C. Tarter, and D. A. Cincotta. 2007. Food habits of the Candy Darter, Etheostoma osburni (Hubbs and Trautman), in the Cherry River, West Virginia. Proceedings of the West Virginia Academy of Science. 79:2.

Stauffer, J. R., J. M. Boltz, and L. R. White. 1995. Fishes of West Virginia. The Proceedings of the Academy of Natural Sciences of Philadelphia. Philadelphia, Pennsylvania.

Strauss, R.E., and F.L. Bookstein. 1982. The truss: body form reconstruction in morphometrics. Systematic Zoology. 31:113-135.

Switzer, J. F. 2004. Molecular systematics and phylogeography of the Etheostoma variatum species group (Actinopterygii: Percidae). Saint Louis University, St. Louis.

Switzer, J. F., S. A. Welsh, and T. L. King. 2007. A molecular genetic investigation of hybridization between Etheostoma osburni and Etheostoma variatum in the New River drainage, West Virginia. Final Report submitted to: West Virginia Division of Natural Resources, Ward Road, Elkins, WV

Switzer, J. F., S. A. Welsh, and T. L. King. 2008. Microsatellite DNA primers for the Candy Darter, Etheostoma osburni and Variegate Darter, Etheostoma variatum, and cross-species amplification in other darters (Percidae). Molecular Ecology Resources. 8.2: 335-338.

Switzer, J. F., and R. M. Wood. 2009. Etheostoma erythrozonum, a new species of darter (Teleostei: Percidae) from the Meramec River drainage, Missouri. Zootaxa. 2095:1-7.

Turner, T. F., and H. W. Robison. 2006. Genetic diversity of the Caddo madtom, Noturus taylori, with comments on factors that promote genetic divergence in fishes endemic to the Ouachita highlands. The Southwestern Naturalist. 51.3:338-345.

United States Fish and Wildlife Service. 1989. Endangered and Threatened Wildlife and Plants; Animal Notice of Review. Federal Register, 54.4:559. 
Van Oosterhout, C., W. F. Hutchinson, D. P. M. Wills, and P. Shipley. 2003. Micro-Checker, version 2.2. 3. Department of Biological Sciences and Department of Computer Science, University of Hull, Hull, UK.

Vilà, C., C. Walker, A. K. Sundqvist, Ø. Flagstad, Z. Andersone, A. Casulli, I. Kojola H. Valdmann, J. Halverson, and H. Ellegren. 2003. Combined use of maternal, paternal and bi-parental genetic markers for the identification of wolf-dog hybrids. Heredity. 90.1:17-24.

Vitousek, P. M., H. A. Mooney, J. Lubchenco, and J. M. Melillo. 1997. Human domination of Earth's ecosystems. Science. 277.5325:494-499.

Walters, D. M., M. J. Blum, B. Rashleigh, B. J. Freeman, B. A. Porter, and N. M. Burkhead. 2008. Red shiner invasion and hybridization with blacktail shiner in the upper Coosa River, USA. Biological Invasions. 10.8:1229-1242.

Ward, J. L., M. J. Blum, D. M. Walters, B. A. Porter, N. Burkhead, and B. Freeman. 2012. Discordant introgression in a rapidly expanding hybrid swarm. Evolutionary applications. 5.4:380-392.

Wilson, C. C., and L. Bernatchez. 1998. The ghost of hybrids past: fixation of arctic charr (Salvelinus alpinus) mitochondrial DNA in an introgressed population of lake trout ( $S$. namaycush). Molecular Ecology. 7.1:127-132.

Wellman, D. I. 2004. Post-flood recovery and distributions of fishes in the New River Gorge National River and the Gauley River National Recreation Area. Master's Thesis, West Virginia University, Morgantown, WV.

Welsh, S. A., and R. M. Wood. 2008. Crystallaria cincotta, a new species of darter (Teleostei: Percidae) from the Elk River of the Ohio River drainage, West Virginia. Zootaxa. 1680:62-68. 


\section{TABLES}

Table 1. List of collection sites enumerated to correspond with map of study area. Total number of specimens, number of pure E. osburni, and percentage of E. variatum alleles of that sample is given. All coordinates are in Zone 17.

\begin{tabular}{|c|c|c|c|c|c|c|c|c|}
\hline Site & Stream & Location Description & Drainage & $\begin{array}{c}\mathbf{n} \\
\text { Total }\end{array}$ & $\stackrel{\mathbf{n}}{\text { E. osburni }}$ & $\begin{array}{c}\% \\
\text { E. variatum } \\
\text { alleles }\end{array}$ & UTM N & UTM E \\
\hline 1 & Bells $\mathrm{C}$. & $\begin{array}{l}1.1 \text { road miles from junction CR } \\
16 \text { X CR } 39\end{array}$ & Gauley & 17 & 0 & 89.41 & 4232887 & 483116 \\
\hline 2 & Gauley R. & $\begin{array}{l}\text { Swiss; Upstream } 0.25 \text { mile on } \\
\text { Swiss Road }\end{array}$ & Gauley & 33 & 0 & 84.55 & 4231525 & 488817 \\
\hline 3 & Gauley R. & $\begin{array}{l}\text { Downstream of Summersville } \\
\text { Dam at USGS gauging station }\end{array}$ & Gauley & 31 & 25 & 1.94 & 4229683 & 509794 \\
\hline 4 & Cherry R. & Rt 20 bridge in Holcomb & Gauley & 35 & 33 & 0.57 & 4234356 & 534874 \\
\hline 5 & Laurel C. & $\begin{array}{l}\text { Namo Chapel; Just above mouth } \\
\text { of McMillion Creek }\end{array}$ & Gauley & 17 & 17 & 0.00 & 4223493 & 536452 \\
\hline 6 & N. F. Cherry R. & $\begin{array}{l}\text { In Richwood at Johnstown Road } \\
\text { bridge; Behind mill }\end{array}$ & Gauley & 17 & 17 & 0.00 & 4231341 & 541739 \\
\hline 7 & S. F. Cherry R. & $\begin{array}{l}\sim 1.05 \text { air miles upstream of } \\
\text { mouth/confluence with North Fork }\end{array}$ & Gauley & 16 & 16 & 0.00 & 4229809 & 543197 \\
\hline 8 & Gauley R. & $\begin{array}{l}\text { Cherry River } \\
\text { Rt 20; } 1.1 \text { Road miles upstream } \\
\text { Camp Caesar }\end{array}$ & Gauley & 7 & 7 & 0.00 & 4250657 & 546185 \\
\hline 9 & Gauley R. & $\begin{array}{l}\text { Bolair; } 2.0 \text { miles south of Rt } 20 \\
\text { from junction CR } 42\end{array}$ & Gauley & 15 & 14 & 0.67 & 4252624 & 546783 \\
\hline 10 & Gauley R. & $\begin{array}{l}\text { On CR } 42 \text { between Rt } 20 \text { and site } \\
9.0 \text { miles above Rt } 20\end{array}$ & Gauley & 2 & 2 & 0.00 & 4253707 & 553975 \\
\hline 11 & Gauley R. & 9.0 miles above Rt 20 on CR 42 & Gauley & 13 & 13 & 0.00 & 4253288 & 559195 \\
\hline 12 & Greenbrier R. & $\begin{array}{l}\text { Riffle above Rt } 219 \text { bridge in } \\
\text { Ronceverte }\end{array}$ & Greenbrier & 31 & 0 & 98.06 & 4177571 & 547282 \\
\hline 13 & Anthony $\mathrm{C}$. & 0.2 air miles above mouth & Greenbrier & 9 & 0 & 98.89 & 4193987 & 559556 \\
\hline 14 & Anthony C. & $\begin{array}{l}\text { At primitive campsite } 0.9 \text { miles } \\
\text { below Blue Bend camp entrance }\end{array}$ & Greenbrier & 9 & 0 & 91.11 & 4196407 & 562946 \\
\hline 15 & Anthony C. & $\begin{array}{l}16 / 2 \text { bridge; near Bluebend } \\
\text { National Recreation Area }\end{array}$ & Greenbrier & 1 & 0 & 100.00 & 4197112 & 565084 \\
\hline 16 & Knapp C. & Above mouth of Browns Creek & Greenbrier & 7 & 1 & 45.71 & 4228162 & 585845 \\
\hline 17 & Knapp C. & $\begin{array}{l}\text { Above first bridge south of Frost } \\
\text { on CR } 92\end{array}$ & Greenbrier & 5 & 4 & 2.00 & 4235260 & 596196 \\
\hline 18 & Sitlington C. & $\begin{array}{l}\text { Just below confluence of Galford } \\
\text { and Shock runs }\end{array}$ & Greenbrier & 13 & 12 & 0.77 & 4244680 & 600001 \\
\hline 19 & Deer C. & $\begin{array}{l}\text { Above Rt } 66 \text { bridge just west of } \\
\text { CR } 92\end{array}$ & Greenbrier & 12 & 8 & 9.17 & 4251247 & 598885 \\
\hline 20 & E. F. Greenbrier R. & CR 28/19 bridge & Greenbrier & 5 & 5 & 0.00 & 4267423 & 607928 \\
\hline 21 & $\begin{array}{l}\text { Little R. E. F. } \\
\text { Greenbrier R. }\end{array}$ & $\begin{array}{l}0.63 \text { miles from intersection Rt } \\
250 \text { X Rt } 28 \text { near Thornwood }\end{array}$ & Greenbrier & 31 & 29 & 0.65 & 4267486 & 610633 \\
\hline \multirow[t]{2}{*}{22} & W. F. Greenbrier R. & $75 \mathrm{~m}$ section above FR312 & Greenbrier & 9 & 8 & 3.33 & 4273165 & 602606 \\
\hline & & & TOTAL & 335 & 211 & & & \\
\hline
\end{tabular}


Table 2. List of sites visited for this study that produced no specimens of either E. osburni or of hybrids. All coordinates are in Zone 17.

\begin{tabular}{|c|c|c|c|c|}
\hline Stream & Location Description & Drainage & UTM N & UTM E \\
\hline Anglins Creek & Rt. 41 bridge & Gauley & 4221131 & 510002 \\
\hline Anthony Creek & Just below Blue Bend swimming area & Greenbrier & 4197386 & 564545 \\
\hline Anthony Creek & Neola. Below mouth of meadow creek. Below CR14 bridge. & Greenbrier & 4202498 & 576267 \\
\hline Becky Run & Just upstream of mouth & Gauley & 4222640 & 547705 \\
\hline Dry Run & CR 17 bridge near hatchery & Greenbrier & 4236281 & 578176 \\
\hline $\begin{array}{l}\text { East Fork } \\
\text { Greenbrier River }\end{array}$ & Above East Fork Greenbrier R. bridge in Durbin & Greenbrier & 4266872 & 602886 \\
\hline Gauley River & Immediately downstream of Bolair & Gauley & 4250259 & 544576 \\
\hline Gauley River & Just downstream of Summersville Dam & Gauley & 4230002 & 509719 \\
\hline Greenbrier River & Below Rt. 219 bridge in Ronceverte & Greenbrier & 4177647 & 546701 \\
\hline Griffith Creek & 1.1 air miles west of Greenbrier River & Greenbrier & 4175907 & 526618 \\
\hline Knapp Creek & 2.0 road miles from CR $39 \mathrm{X}$ Greenbrier River bridge in Marlinton & Greenbrier & 4229820 & 581451 \\
\hline Knapp Creek & In Marlinton. Above 39/2 (5th Avenue) bridge & Greenbrier & 4230537 & 579296 \\
\hline Laurel Creek & First crossing (19/25) just above Swiss & Gauley & 4230728 & 489701 \\
\hline Leatherbark Run & By CR 1. Above impoundment at Cass Scenic Railroad Workshop & Greenbrier & 4251123 & 594956 \\
\hline Meadow River & Old railroad trestle, now a footbridge & Gauley & 4214920 & 509435 \\
\hline $\begin{array}{l}\text { North Fork Deer } \\
\text { Creek }\end{array}$ & Above CR 6 bridge & Greenbrier & 4253331 & 604078 \\
\hline Rich Creek & $\sim 150 \mathrm{~m}$ upstream mouth above first bridge to abandoned RR bridge & Gauley & 4230814 & 486695 \\
\hline Rosen Run & First bridge upstream confluence with North Fork Deer Creek & Greenbrier & 4252137 & 601988 \\
\hline Second Creek & .2 miles above Rt. 219 at CR $219 / 1$ bridge & Greenbrier & 4170760 & 548030 \\
\hline Sitlington Creek & CR 28/26 halfway between each terminus at Rt. 28 & Greenbrier & 4246726 & 597894 \\
\hline $\begin{array}{l}\text { South Fork Cherry } \\
\text { River }\end{array}$ & Above mouth of Little Blizzard Run & Gauley & 4220967 & 550909 \\
\hline Swago Creek & $228 \mathrm{~m}$ below US 219 bridge & Greenbrier & 4227590 & 575685 \\
\hline Williams River & $\sim 1$ mile above bridge on Woodrow Rd near Handley. & Gauley & 4238848 & 569372 \\
\hline
\end{tabular}


Table 3. Meristic characters evaluated for F1 hybrids and for E. osburni (data for Gauley and Greenbrier populations of E. osburni is combined). Data for E. variatum is from Page (1983) and Page and Burr (2011).

\begin{tabular}{|c|c|c|c|c|c|c|c|c|c|c|c|}
\hline \multirow{2}{*}{ Character } & \multicolumn{5}{|c|}{ E. osburni $(\mathrm{n}=41)$} & \multicolumn{5}{|c|}{ F1 Hybrid $(\mathrm{n}=4)$} & \multirow{2}{*}{ E. variatum } \\
\hline & Min & $\operatorname{Max}$ & Mean & $\mathrm{SD}$ & Mode & Min & $\operatorname{Max}$ & Mean & SD & Mode & \\
\hline Dorsal-fin spines & 11 & 13 & 12.2 & 0.44 & 12 & 12 & 14 & 12.75 & 0.96 & NA & $11-13$ \\
\hline Dorsal-fin rays & 12 & 15 & 13.4 & 0.70 & 13 & 13 & 13 & 13.00 & 0.00 & 13 & $12-16(13)$ \\
\hline Pectoral-fin rays & 13 & 16 & 14.6 & 0.60 & 15 & 14 & 15 & 14.75 & 0.50 & NA & $14-16(15)$ \\
\hline Pelvic-fin rays & 5 & 6 & 5.07 & 0.26 & 5 & 5 & 5 & 5.00 & 0.00 & 5 & \\
\hline Pelvic-fin spines & 1 & 1 & 1.00 & 0.00 & 1 & 1 & 1 & 1.00 & 0.00 & 1 & \\
\hline Anal-fin rays & 8 & 11 & 9.44 & 0.65 & 9 & 8 & 10 & 9.00 & 1.15 & NA & $8-10(9-10)$ \\
\hline Anal-fin spines & 2 & 2 & 2 & 0.00 & 2 & 2 & 2 & 2.00 & 0.00 & 2 & 2 \\
\hline Scales above lateral line & 6 & 9 & 7.51 & 0.64 & 7 & 7 & 8 & 7.25 & 0.50 & NA & $6-8(6-7)$ \\
\hline Scales below lateral line & 8 & 11 & 9.37 & 0.77 & 9 & 8 & 10 & 9.00 & 0.82 & NA & $7-10(8-9)$ \\
\hline $\begin{array}{l}\text { Scales along lateral line } \\
\text { (left) }\end{array}$ & 58 & 71 & 64.44 & 2.90 & 64 & 55 & 63 & 60.25 & 3.59 & NA & $48-60(50-56)$ \\
\hline $\begin{array}{l}\text { Scales along lateral line } \\
\text { (right) }\end{array}$ & 59 & 71 & 64.39 & 2.72 & 68 & 54 & 62 & 58.75 & 3.4 & NA & $48-60(50-56)$ \\
\hline Circumpeduncle scales & 21 & 27 & 23.59 & 1.12 & 23 & 21 & 24 & 22.75 & 1.26 & NA & $20-25(21-23)$ \\
\hline Dark lateral bars & 10 & 14 & 11.73 & 1.19 & 12 & 7 & 10 & 8.33 & 1.53 & NA & \\
\hline Dorsolateral saddles & 4 & 5 & 4.88 & 0.33 & 5 & 4 & 5 & 4.33 & 0.58 & NA & 4 \\
\hline Dorsal-fin saddle & \multicolumn{5}{|c|}{$95.1 \%$ of specimens } & \multicolumn{5}{|c|}{$0 \%$ of specimens } & \\
\hline $\begin{array}{l}\text { Breast squamation } \\
\text { (embedded) }\end{array}$ & \multicolumn{5}{|c|}{$43.9 \%$ of specimens } & \multicolumn{5}{|c|}{$25 \%$ of specimens } & NA \\
\hline $\begin{array}{l}\text { Breast squamation } \\
\text { (exposed) }\end{array}$ & \multicolumn{5}{|c|}{ unscaled } & \multicolumn{5}{|c|}{$0 \%$ of specimens } & scaled \\
\hline Opercle squamation & \multicolumn{5}{|c|}{ unscaled } & \multicolumn{5}{|c|}{$25 \%$ of specimens } & variable \\
\hline Supraopercular squamation & \multicolumn{5}{|c|}{ unscaled } & \multicolumn{5}{|c|}{$75 \%$ of specimens } & \\
\hline
\end{tabular}


Table 4. Sites represented in each sample used in STRUCTURE analysis, construction of a neighborjoining tree, and for pairwise comparison of $F_{S T}$.

\begin{tabular}{|c|c|c|c|c|c|c|}
\hline Sample & $\mathbf{n}_{\text {Sample }}$ & Drainage & No. & Stream & Location Description & $\mathbf{n}_{\text {Site }}$ \\
\hline $\begin{array}{l}\text { Little R. E. Fk. } \\
\text { Greenbrier R. }\end{array}$ & 29 & Greenbrier & 21 & $\begin{array}{l}\text { Little River East Fork } \\
\text { Greenbrier River }\end{array}$ & $\begin{array}{l}.63 \text { miles from intersection Rt } 250 \mathrm{X} \\
\text { Rt } 28 \text { near Thornwood }\end{array}$ & 29 \\
\hline \multirow{2}{*}{ Upper Greenbrier R. } & \multirow{2}{*}{13} & \multirow{2}{*}{ Greenbrier } & 20 & East Fork Greenbrier River & CR 28/19 bridge & 5 \\
\hline & & & 22 & West Fork Greenbrier River & $75 \mathrm{~m}$ section above FR 312 & 8 \\
\hline Sitlington C. & 12 & Greenbrier & 18 & Sitlington Creek & $\begin{array}{l}\text { Just below confluence of Galford } \\
\text { Run and Shock Run }\end{array}$ & 12 \\
\hline \multirow{3}{*}{ Mid-Greenbrier R. } & \multirow{3}{*}{13} & \multirow{3}{*}{ Greenbrier } & 16 & Knapp Creek & Above mouth of Browns Creek & 1 \\
\hline & & & 17 & Knapp Creek & $\begin{array}{l}\text { Above first bridge south of Frost on } \\
\text { CR } 92\end{array}$ & 4 \\
\hline & & & 19 & Deer Creek & Above Rt 66 Bridge just West of 92 & 8 \\
\hline Laurel C. & 17 & Gauley & 5 & Laurel Creek & Namo Chapel & 17 \\
\hline Cherry R. & 33 & Gauley & 4 & Cherry River & Rt 20 Bridge in Holcomb & 33 \\
\hline N. Fk. Cherry R. & 17 & Gauley & 6 & North Fork Cherry River & $\begin{array}{l}\text { In Richwood at Johnstown Road } \\
\text { Bridge. Behind... }\end{array}$ & 17 \\
\hline S. Fk. Cherry R. & 16 & Gauley & 7 & South Fork Cherry River & $\begin{array}{l}\sim 1.05 \text { air miles above } \\
\text { mouth/confluence with... }\end{array}$ & 16 \\
\hline \multirow{4}{*}{ Upper Gauley R. } & \multirow{4}{*}{36} & \multirow{4}{*}{ Gauley } & 9 & Gauley River & $\begin{array}{l}\text { Bolair. } 2.0 \text { miles south of Rt } 20 \text { from } \\
\text { junction CR } 4\end{array}$ & 14 \\
\hline & & & 10 & Gauley River & $\begin{array}{l}\text { On CR } 42 \text { between SR } 20 \text { and the site } \\
\text { which was } 9 \text { miles from SR } 20\end{array}$ & 2 \\
\hline & & & 8 & Gauley River & $\begin{array}{l}\text { Rt 20; } 1.1 \text { Road miles upstream } \\
\text { Camp Caesar }\end{array}$ & 7 \\
\hline & & & 11 & Gauley River & 9 miles above SR 20 on CR 42 & 13 \\
\hline Lower Gauley R. & 25 & \multirow[t]{2}{*}{ Gauley } & \multirow[t]{2}{*}{3} & \multirow[t]{2}{*}{ Gauley River } & \multirow[t]{2}{*}{$\begin{array}{l}\text { USGS Gauging Station just below } \\
\text { Summersville Dam }\end{array}$} & \multirow[t]{2}{*}{25} \\
\hline TOTAL & 211 & & & & & \\
\hline
\end{tabular}


Table 5. Morphometric distances used in shape analysis of E. osburni. Variable enumeration corresponds to Figures 15 and 16. Box truss distance measurements, head length, outer-pelvic width, and caudal length $(1-23,26,31)$ are presented as thousandths of standard length. Measurements taken on the head $(24,25,27-30)$ are presented as thousandths of head length.

\begin{tabular}{|c|c|c|c|c|c|c|c|c|c|}
\hline \multirow{2}{*}{ No. } & \multirow{2}{*}{ Distance } & \multicolumn{4}{|c|}{ Gauley $(n=16)$} & \multicolumn{4}{|c|}{ Greenbrier $(n=25)$} \\
\hline & & Min & Max & Mean & SD & Min & Max & Mean & SD \\
\hline $\mathrm{SL}$ & Standard length $(\mathrm{mm})$ & 63.1 & 85.8 & 74.2 & 4.9 & 57.8 & 84.2 & 70.3 & 7.1 \\
\hline 1 & Snout - occiput & 200 & 221 & 212 & 6.1 & 198 & 221 & 210 & 6.6 \\
\hline 2 & Occiput - first dorsal-fin spine & 105 & 145 & 124 & 10.7 & 104 & 145 & 130 & 10.9 \\
\hline 3 & Base of first dorsal fin & 294 & 343 & 320 & 12.1 & 273 & 349 & 315 & 17.1 \\
\hline 4 & Base of second dorsal fin & 184 & 230 & 205 & 10.8 & 194 & 240 & 215 & 11.3 \\
\hline 5 & $\begin{array}{l}\text { Last dorsal fin ray - dorsal caudal } \\
\text { flexure }\end{array}$ & 166 & 192 & 176 & 6.8 & 152 & 193 & 171 & 10.7 \\
\hline 6 & Depth at caudal flexure & 113 & 150 & 127 & 9.6 & 113 & 144 & 124 & 6.0 \\
\hline 7 & $\begin{array}{l}\text { Last anal-fin ray - ventral caudal } \\
\text { flexure }\end{array}$ & 208 & 243 & 227 & 9.8 & 203 & 241 & 218 & 9.0 \\
\hline 8 & Base of anal fin & 140 & 171 & 158 & 8.5 & 139 & 182 & 162 & 10.4 \\
\hline 9 & $\begin{array}{l}\text { Mid-point between pelvic-fin bases - } \\
\text { first anal-fin ray }\end{array}$ & 287 & 340 & 314 & 13.0 & 291 & 344 & 318 & 14.4 \\
\hline 10 & $\begin{array}{l}\text { Branchiostegal connection - midpoint } \\
\text { between pelvic-fin bases }\end{array}$ & 202 & 228 & 215 & 6.0 & 189 & 236 & 202 & 12.3 \\
\hline 11 & Snout - branchiostegal connection & 91 & 111 & 101 & 5.3 & 92 & 136 & 104 & 8.2 \\
\hline 12 & Branchiostegal connection - occiput & 164 & 188 & 175 & 5.6 & 150 & 181 & 167 & 8.3 \\
\hline 13 & $\begin{array}{l}\text { Branchiostegal connection - first } \\
\text { dorsal-fin spine }\end{array}$ & 250 & 289 & 273 & 10.2 & 246 & 290 & 269 & 11.3 \\
\hline 14 & $\begin{array}{l}\text { Occiput - mid-point between pelvic } \\
\text { fin bases }\end{array}$ & 210 & 240 & 219 & 7.7 & 194 & 233 & 211 & 10.2 \\
\hline 15 & $\begin{array}{l}\text { Mid-point between pelvic fin bases - } \\
\text { first dorsal-fin spine }\end{array}$ & 184 & 217 & 200 & 9.9 & 180 & 228 & 201 & 10.9 \\
\hline 16 & $\begin{array}{l}\text { Mid-point between pelvic fin bases - } \\
\text { second dorsal-fin origin }\end{array}$ & 352 & 388 & 361 & 10.6 & 317 & 392 & 361 & 17.0 \\
\hline 17 & First dorsal fin spine -anal-fin origin & 366 & 398 & 383 & 8.3 & 352 & 397 & 377 & 13.2 \\
\hline 18 & $\begin{array}{l}\text { Anal-fin origin - second dorsal-fin } \\
\text { origin }\end{array}$ & 179 & 214 & 198 & 8.8 & 173 & 212 & 190 & 10.3 \\
\hline 19 & Anal-fin origin - last dorsal-fin ray & 233 & 270 & 253 & 8.9 & 222 & 271 & 251 & 12.7 \\
\hline
\end{tabular}




\begin{tabular}{|c|c|c|c|c|c|c|c|c|c|}
\hline 20 & $\begin{array}{l}\text { Second dorsal-fin origin - last anal- } \\
\text { fin ray }\end{array}$ & 224 & 259 & 236 & 9.4 & 222 & 256 & 239 & 9.0 \\
\hline 21 & Last dorsal-fin ray - last anal-fin ray & 130 & 149 & 136 & 5.0 & 114 & 138 & 125 & 5.9 \\
\hline 22 & $\begin{array}{l}\text { Last anal-fin ray - dorsal caudal } \\
\text { flexure }\end{array}$ & 248 & 284 & 264 & 9.2 & 231 & 271 & 252 & 10.4 \\
\hline 23 & $\begin{array}{l}\text { Last dorsal-fin ray - ventral caudal } \\
\text { flexure }\end{array}$ & 203 & 234 & 220 & 9.0 & 189 & 227 & 211 & 9.1 \\
\hline 24 & Snout - anterior margin of eye & 338 & 381 & 358 & 13.7 & 314 & 397 & 356 & 19.0 \\
\hline 25 & Eye width & 207 & 236 & 221 & 8.3 & 213 & 251 & 230 & 8.2 \\
\hline 26 & Snout - opercle spine tip & 230 & 256 & 243 & 6.4 & 226 & 258 & 238 & 7.2 \\
\hline 27 & Anterior internasal width & 151 & 182 & 166 & 10.0 & 147 & 187 & 166 & 9.1 \\
\hline 28 & Posterior internasal width & 144 & 196 & 165 & 11.7 & 145 & 183 & 168 & 10.1 \\
\hline 29 & Interorbital width & 122 & 172 & 150 & 13.5 & 104 & 159 & 137 & 14.9 \\
\hline 30 & Gape width & 270 & 324 & 294 & 13.5 & 239 & 339 & 285 & 24.3 \\
\hline 31 & Outerpelvic base width & 86 & 115 & 101 & 5.8 & 94 & 107 & 100 & 3.7 \\
\hline 32 & Caudal-fin length & 175 & 194 & 186 & 5.4 & 97 & 193 & 171 & 17.7 \\
\hline
\end{tabular}


Table 6. Meristic characters evaluated for Gauley and Greenbrier populations of E. osburni. Data for E. osburni from Page (1983) and Page and Burr (2011) is given.

\begin{tabular}{|c|c|c|c|c|c|c|c|c|c|c|c|}
\hline \multirow[b]{2}{*}{ Character } & \multirow{2}{*}{$\begin{array}{c}\text { Page } \\
(1983) ; \\
\text { Page and } \\
\text { Burr } \\
(2011)\end{array}$} & \multicolumn{5}{|c|}{ Gauley $(n=16)$} & \multicolumn{5}{|c|}{ Greenbrier $(n=25)$} \\
\hline & & Min & $\operatorname{Max}$ & Mean & SD & Mode & Min & $\operatorname{Max}$ & Mean & SD & Mode \\
\hline Dorsal-fin spines & $\begin{array}{c}10-14 \\
(12-13)\end{array}$ & 12 & 13 & 12.31 & 0.48 & 12 & 11 & 13 & 12.12 & 0.44 & 12 \\
\hline Dorsal-fin rays & $\begin{array}{c}12-16 \\
(13-14)\end{array}$ & 12 & 14 & 13.06 & 0.68 & 13 & 13 & 15 & 13.64 & 0.70 & 13 \\
\hline Pectoral-fin rays & & 13 & 15 & 14.25 & 0.68 & 14 & 13 & 16 & 14.76 & 0.60 & 15 \\
\hline Pelvic-fin rays & $\begin{array}{c}14-15 \\
(15)\end{array}$ & 5 & 6 & 5.19 & 0.40 & 5 & 5 & 5 & 5.00 & 0.00 & 5 \\
\hline Pelvic-fin spines & & 1 & 1 & 1.00 & 0.00 & 1 & 1 & 1 & 1.00 & 0.00 & 1 \\
\hline Anal-fin rays & $\begin{array}{c}8-11 \\
(9-10)\end{array}$ & 9 & 10 & 9.25 & 0.45 & 9 & 8 & 11 & 9.56 & 0.65 & 10 \\
\hline Anal-fin spines & 2 & 2 & 2 & 2.00 & 0.00 & 2 & 2 & 2 & 2.00 & 0.00 & 2 \\
\hline Scales above lateral line & $6-9(8)$ & 7 & 9 & 7.75 & 0.86 & 7 & 6 & 8 & 7.36 & 0.64 & 7 \\
\hline Scales below lateral line & $\begin{array}{l}8-13 \\
(9-10)\end{array}$ & 8 & 10 & 9.25 & 0.77 & 10 & 8 & 12 & 9.44 & 0.77 & 9 \\
\hline Scales along lateral line (Left) & $\begin{array}{c}58-70 \\
(62-66)\end{array}$ & 60 & 66 & 63.31 & 1.78 & 64 & 58 & 71 & 65.16 & 2.90 & 62 \\
\hline Scales along lateral line (Right) & $58-70$ & 59 & 68 & 63.38 & 2.78 & 63 & 60 & 71 & 65.04 & 2.72 & 68 \\
\hline Circumpeduncle scales & $\begin{array}{c}21-25 \\
(22-24)\end{array}$ & 22 & 27 & 23.81 & 1.11 & 24 & 21 & 25 & 23.44 & 1.12 & 23 \\
\hline Dark lateral bars & & 11 & 13 & 12.25 & 0.58 & 12 & 10 & 14 & 11.40 & 1.19 & 12 \\
\hline Dorsolateral saddles & 5 & 4 & 5 & 4.88 & 0.34 & 5 & 4 & 5 & 4.88 & 0.33 & 5 \\
\hline Dorsal-fin saddle & & \multicolumn{5}{|c|}{$100 \%$ of specimens } & \multicolumn{5}{|c|}{$92.0 \%$ of specimens } \\
\hline Breast squamation (embedded) & & \multicolumn{5}{|c|}{$12.5 \%$ of specimens } & \multicolumn{5}{|c|}{$64 \%$ of specimens } \\
\hline Breast squamation (exposed) & unscaled & \multicolumn{5}{|c|}{ unscaled } & \multicolumn{5}{|c|}{ unscaled } \\
\hline Opercle squamation & variable & \multicolumn{5}{|c|}{ unscaled } & \multicolumn{5}{|c|}{ unscaled } \\
\hline Supraopercular squamation & & \multicolumn{5}{|c|}{ unscaled } & \multicolumn{5}{|c|}{ unscaled } \\
\hline
\end{tabular}


Table 7. Results of HWE calculation for each population of E. osburni per locus and across all loci using Fisher's Method (Fisher 1935). Weir and Cockerham (1984) estimate of $F_{I S}$ is given.

\begin{tabular}{llccc}
\hline Population & Locus & P-value & S.E. & F $_{\text {IS }}$ \\
\hline Greenbrier & Eos-C2 & 1.000 & 0.000 & -0.091 \\
& Eos-C112 & 0.273 & 0.021 & 0.062 \\
& Eos-C3 & 1.000 & 0.000 & -0.023 \\
& Eos-C6 & 0.454 & 0.024 & -0.003 \\
& Eos-C117 & 0.757 & 0.014 & -0.134 \\
& All & 0.908 & & \\
Gauley & & & & \\
& Eos-C2 & 0.179 & 0.005 & -0.122 \\
& Eos-C112 & 0.244 & 0.018 & 0.058 \\
& Eos-C3 & \multicolumn{2}{c}{ No information } \\
& Eos-C6 & 0.641 & 0.009 & 0.025 \\
& Eos-C117 & 0.760 & 0.008 & -0.010 \\
& All & 0.463 & \multicolumn{2}{c}{} \\
\hline
\end{tabular}


Table 8. Results of HWE calculation for each sample of E. osburni (as described in Table 4) per locus and across all loci using Fisher's Method (Fisher 1935). Weir and Cockerham (1984) estimate of FIS is given.

\begin{tabular}{|c|c|c|c|c|}
\hline Population & Locus & $\begin{array}{c}\text { P- } \\
\text { value }\end{array}$ & S.E. & $\mathbf{F}_{\text {IS }}$ \\
\hline \multirow[t]{6}{*}{ Little R. E. Fk. Greenbrier R. } & Eos-C2 & 1.000 & 0.000 & -0.037 \\
\hline & Eos-C112 & 0.271 & 0.013 & 0.136 \\
\hline & $\operatorname{Eos}-C 3$ & 1.000 & 0.000 & -0.037 \\
\hline & Eos-C6 & 0.362 & 0.015 & 0.023 \\
\hline & Eos-C117 & 0.631 & 0.008 & -0.243 \\
\hline & All & 0.850 & & \\
\hline \multirow[t]{6}{*}{ Upper Greenbrier R. } & $\operatorname{Eos}-C 2$ & 1.000 & 0.000 & -0.044 \\
\hline & Eos-C112 & 0.352 & 0.016 & 0.140 \\
\hline & Eos-C3 & \multicolumn{3}{|c|}{ No Information } \\
\hline & Eos-C6 & 0.254 & 0.009 & 0.247 \\
\hline & Eos-C117 & 0.329 & 0.009 & 0.032 \\
\hline & All & 0.531 & & \\
\hline \multirow[t]{6}{*}{ Sitlington C. } & Eos-C2 & 1.000 & 0.000 & -0.044 \\
\hline & Eos-C112 & 0.521 & 0.011 & 0.036 \\
\hline & $\operatorname{Eos}-C 3$ & \multicolumn{3}{|c|}{ No Information } \\
\hline & Eos-C6 & 0.564 & 0.009 & -0.200 \\
\hline & Eos-C117 & 0.861 & 0.005 & -0.061 \\
\hline & All & 0.949 & & \\
\hline \multirow[t]{6}{*}{ Mid-Greenbrier R. } & Eos-C2 & 1.000 & 0.000 & -0.044 \\
\hline & Eos-C112 & 0.085 & 0.006 & -0.136 \\
\hline & Eos-C3 & \multicolumn{3}{|c|}{ No Information } \\
\hline & Eos-C6 & 1.000 & 0.000 & -0.169 \\
\hline & Eos-C117 & 0.277 & 0.007 & 0.203 \\
\hline & All & 0.483 & & \\
\hline \multirow[t]{6}{*}{ Laurel C. } & $\operatorname{Eos}-C 2$ & 0.729 & 0.002 & -0.085 \\
\hline & Eos-C112 & 0.071 & 0.008 & 0.197 \\
\hline & Eos-C3 & \multicolumn{3}{|c|}{ No Information } \\
\hline & Eos-C6 & 0.589 & 0.006 & 0.073 \\
\hline & Eos-C117 & 0.172 & 0.005 & -0.147 \\
\hline & All & 0.231 & & \\
\hline
\end{tabular}




\begin{tabular}{|c|c|c|c|c|}
\hline \multirow[t]{6}{*}{ Cherry R. } & $\operatorname{Eos}-C 2$ & 1.000 & 0.000 & -0.044 \\
\hline & Eos-C112 & 0.662 & 0.005 & 0.103 \\
\hline & Eos-C3 & \multicolumn{3}{|c|}{ No Information } \\
\hline & Eos-C6 & 0.474 & 0.006 & 0.202 \\
\hline & Eos-C117 & 0.510 & 0.005 & 0.135 \\
\hline & All & 0.886 & & \\
\hline \multirow[t]{6}{*}{ N. Fk. Cherry R. } & Eos-C2 & 0.309 & 0.003 & -0.353 \\
\hline & Eos-C112 & 0.366 & 0.009 & 0.236 \\
\hline & $\operatorname{Eos}-C 3$ & \multicolumn{3}{|c|}{ No Information } \\
\hline & Eos-C6 & 0.232 & 0.005 & 0.052 \\
\hline & Eos-C117 & 0.626 & 0.005 & -0.200 \\
\hline & All & 0.413 & & \\
\hline \multirow[t]{6}{*}{ S. Fk. Cherry R. } & Eos-C2 & 0.518 & 0.003 & 0.125 \\
\hline & Eos-C112 & 0.515 & 0.016 & -0.100 \\
\hline & Eos-C3 & \multicolumn{3}{|c|}{ No Information } \\
\hline & Eos-C6 & 0.587 & 0.006 & -0.067 \\
\hline & Eos-C117 & 1.000 & 0.000 & -0.048 \\
\hline & All & 0.883 & & \\
\hline \multirow[t]{6}{*}{ Upper Gauley R. } & Eos-C2 & 0.052 & 0.001 & -0.426 \\
\hline & Eos-C112 & 0.767 & 0.006 & -0.056 \\
\hline & Eos-C3 & \multicolumn{3}{|c|}{ No Information } \\
\hline & Eos-C6 & 0.544 & 0.006 & -0.058 \\
\hline & Eos-C117 & 1.000 & 0.000 & -0.095 \\
\hline & All & 0.469 & & \\
\hline \multirow[t]{6}{*}{ Lower Gauley R. } & Eos-C2 & 1.000 & 0.000 & -0.222 \\
\hline & Eos-C112 & 0.974 & 0.003 & -0.158 \\
\hline & Eos-C3 & \multicolumn{3}{|c|}{ No Information } \\
\hline & Eos-C6 & 0.725 & 0.011 & -0.158 \\
\hline & Eos-C117 & 1.000 & 0.000 & -0.100 \\
\hline & All & 1.000 & & \\
\hline
\end{tabular}


Table 9. Pairwise comparison of $\mathrm{F}_{\mathrm{ST}}$ among samples (as described in Table 4; above the diagonal) with P-values obtained after 900 permutations (below the diagonal). Indicative adjusted nominal level (5\%) for multiple comparisons is 0.001 . Significant values are listed in bold font.

\begin{tabular}{|c|c|c|c|c|c|c|c|c|c|c|c|}
\hline & \multirow[b]{2}{*}{ Sample } & \multicolumn{4}{|c|}{ Greenbrier River drainage } & \multicolumn{6}{|c|}{ Gauley River drainage } \\
\hline & & $\begin{array}{l}\text { Little R. E. F. } \\
\text { Greenbrier R. }\end{array}$ & $\begin{array}{c}\text { Upper } \\
\text { Greenbrier } \\
\text { R. }\end{array}$ & $\begin{array}{l}\text { Sitlington } \\
\text { C. }\end{array}$ & $\begin{array}{c}\text { Mid- } \\
\text { Greenbrier R. }\end{array}$ & $\begin{array}{l}\text { Laurel } \\
\text { C. }\end{array}$ & $\begin{array}{l}\text { Cherry } \\
\text { R. }\end{array}$ & $\begin{array}{l}\text { N. F. } \\
\text { Cherry R. }\end{array}$ & $\begin{array}{c}\text { S. F. } \\
\text { Cherry R. }\end{array}$ & $\begin{array}{c}\text { Upper } \\
\text { Gauley R. }\end{array}$ & $\begin{array}{c}\text { Lower } \\
\text { Gauley R. }\end{array}$ \\
\hline \multirow{4}{*}{ 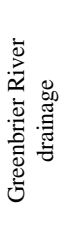 } & $\begin{array}{l}\text { Little R. E. F. } \\
\text { Greenbrier R. }\end{array}$ & 0.000 & -0.008 & 0.001 & -0.008 & 0.186 & 0.145 & 0.160 & 0.162 & 0.201 & 0.136 \\
\hline & $\begin{array}{c}\text { Upper } \\
\text { Greenbrier R. }\end{array}$ & 0.251 & 0.000 & 0.008 & -0.004 & 0.142 & 0.121 & 0.134 & 0.122 & 0.179 & 0.104 \\
\hline & Sitlington C. & 0.026 & 0.051 & 0.000 & -0.005 & 0.147 & 0.110 & 0.122 & 0.123 & 0.161 & 0.103 \\
\hline & $\begin{array}{l}\text { Mid-Greenbrier } \\
\text { R. }\end{array}$ & 0.644 & 0.242 & 0.307 & 0.000 & 0.159 & 0.123 & 0.147 & 0.150 & 0.205 & 0.130 \\
\hline \multirow{6}{*}{ 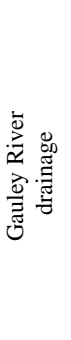 } & Laurel C. & 0.001 & 0.001 & 0.001 & 0.001 & 0.000 & $\begin{array}{c}0.012 \\
4\end{array}$ & 0.017 & -0.006 & 0.085 & 0.026 \\
\hline & Cherry R. & 0.001 & 0.001 & 0.001 & 0.001 & 0.084 & 0.000 & -0.011 & 0.012 & 0.046 & 0.011 \\
\hline & N. F. Cherry R. & 0.001 & 0.001 & 0.001 & 0.001 & 0.354 & 0.619 & 0.000 & -0.002 & 0.009 & 0.000 \\
\hline & S. F. Cherry R. & 0.001 & 0.001 & 0.001 & 0.001 & 0.710 & 0.342 & 0.708 & 0.000 & 0.036 & -0.005 \\
\hline & Upper Gauley R. & 0.001 & 0.001 & 0.001 & 0.001 & 0.001 & 0.002 & 0.0578 & 0.018 & 0.000 & 0.012 \\
\hline & Lower Gauley R. & 0.001 & 0.001 & 0.001 & 0.001 & 0.011 & 0.398 & 0.226 & 0.527 & 0.143 & 0.000 \\
\hline
\end{tabular}


Table 10. Allelic frequency for the Gauley and Greenbrier populations of E. osburni $\left(\mathrm{n}_{\text {Gauely }}=67\right.$; $\mathrm{n}_{\text {Greenbrier }}=144 ; \mathrm{n}_{\text {Total }}=211$ ). The status as a private allele is indicated.

\begin{tabular}{lccccc}
\hline Locus & Size (bp) & Greenbrier & Gauley & Overall & Private \\
\hline Eos-C2 & 108 & 0.090 & 0.490 & 0.363 & \\
Eos-C2 & 112 & 0.910 & 0.510 & 0.637 & \\
& & & & & \\
Eos-C112 & 149 & 0.090 & 0.215 & 0.175 & \\
Eos-C112 & 161 & 0.015 & 0.010 & 0.012 & \\
Eos-C112 & 165 & 0.119 & 0.000 & 0.038 & Greenbrier \\
Eos-C112 & 169 & 0.015 & 0.004 & 0.007 & \\
Eos-C112 & 173 & 0.179 & 0.063 & 0.100 & \\
Eos-C112 & 177 & 0.239 & 0.000 & 0.076 & Greenbrier \\
Eos-C112 & 181 & 0.082 & 0.000 & 0.026 & Greenbrier \\
Eos-C112 & 185 & 0.246 & 0.670 & 0.536 & \\
Eos-C112 & 189 & 0.008 & 0.035 & 0.026 & \\
Eos-C112 & 193 & 0.008 & 0.004 & 0.005 & \\
Eos-C3 & 209 & 0.970 & 1.000 & 0.991 & \\
Eos-C3 & 213 & 0.030 & 0.000 & 0.010 & Greenbrier \\
& & & & & \\
Eos-C6 & 244 & 0.022 & 0.000 & 0.007 & Greenbrier \\
Eos-C6 & 248 & 0.276 & 0.285 & 0.282 & \\
Eos-C6 & 252 & 0.515 & 0.288 & 0.360 & \\
Eos-C6 & 256 & 0.060 & 0.316 & 0.235 & \\
Eos-C6 & 260 & 0.060 & 0.111 & 0.095 & \\
Eos-C6 & 268 & 0.015 & 0.000 & 0.005 & Greenbrier \\
Eos-C6 & 272 & 0.022 & 0.000 & 0.007 & Greenbrier \\
Eos-C6 & 276 & 0.022 & 0.000 & 0.007 & Greenbrier \\
Eos-C6 & 280 & 0.008 & 0.000 & 0.002 & Greenbrier \\
Eos-C117 & 245 & 0.008 & 0.000 & 0.002 & Greenbrier \\
Eos-C117 & 253 & 0.008 & 0.000 & 0.002 & Greenbrier \\
Eos-C117 & 257 & 0.097 & 0.000 & 0.031 & Greenbrier \\
Eos-C117 & 261 & 0.702 & 0.653 & 0.668 & \\
Eos-C117 & 265 & 0.164 & 0.306 & 0.261 & \\
Eos-C117 & 269 & 0.022 & 0.031 & 0.028 & \\
Eos-C117 & 273 & 0.000 & 0.010 & 0.007 & Gauley \\
\hline & & & & & \\
\hline
\end{tabular}


Table 11. Summary of allelic variation of Gauley and Greenbrier populations of E. osburni including number of alleles, allelic size range, allelic richness, observed heterozygosity $\left(\mathrm{H}_{\mathrm{o}}\right)$, and expected heterozygosity $\left(\mathrm{H}_{\mathrm{e}}\right)$.

\begin{tabular}{|c|c|c|c|c|c|c|}
\hline Population & Locus & No. Alleles & $\begin{array}{c}\text { Size Range } \\
\text { (bp) }\end{array}$ & $\begin{array}{c}\text { Allelic } \\
\text { Richness }\end{array}$ & $\mathbf{H}_{\mathbf{o}}$ & $\mathbf{H}_{\mathbf{e}}$ \\
\hline \multirow{7}{*}{$\begin{array}{l}\text { Gauley } \\
\mathrm{n}=144\end{array}$} & $\operatorname{Eos}-C 2$ & 2 & $108-112$ & 2.000 & 0.563 & 0.502 \\
\hline & Eos-C112 & 7 & $149-193$ & 5.777 & 0.472 & 0.501 \\
\hline & Eos-C3 & 1 & 209 & 1.000 & 0.000 & - \\
\hline & Eos-C6 & 4 & $248-260$ & 4.000 & 0.708 & 0.726 \\
\hline & Eos-C117 & 4 & $261-273$ & 3.845 & 0.486 & 0.481 \\
\hline & Mean & & & 3.324 & 0.557 & 0.552 \\
\hline & SD & & & 1.864 & 0.108 & 0.116 \\
\hline \multirow{7}{*}{$\begin{array}{l}\text { Greenbrier } \\
n=67\end{array}$} & $\operatorname{Eos}-C 2$ & 2 & $108-112$ & 2.000 & 0.179 & 0.164 \\
\hline & Eos-C112 & 10 & $149-193$ & 10.000 & 0.776 & 0.827 \\
\hline & Eos-C3 & 2 & $209-213$ & 2.000 & 0.060 & 0.058 \\
\hline & Eos-C6 & 9 & $244-280$ & 9.000 & 0.657 & 0.655 \\
\hline & Eos-C117 & 6 & $245-269$ & 6.000 & 0.537 & 0.474 \\
\hline & Mean & & & 5.800 & 0.442 & 0.436 \\
\hline & SD & & & 3.768 & 0.309 & 0.323 \\
\hline \multirow{7}{*}{$\begin{array}{l}\text { Total } \\
\mathrm{n}=211\end{array}$} & $\operatorname{Eos}-C 2$ & 2 & $108-112$ & 2.000 & - & 0.463 \\
\hline & Eos-C112 & 10 & $149-193$ & 9.041 & - & 0.665 \\
\hline & Eos-C3 & 2 & $209-213$ & 1.785 & - & 0.019 \\
\hline & Eos-C6 & 9 & $244-280$ & 6.902 & - & 0.728 \\
\hline & Eos-C117 & 7 & $245-273$ & 5.302 & - & 0.485 \\
\hline & Mean & & & 5.006 & - & 0.472 \\
\hline & SD & & & 3.137 & - & 0.278 \\
\hline
\end{tabular}


Table 12. Summary of 20 repeated measurements on a single individual for error quantification of morphometric distances. All values are presented in millimeters.

\begin{tabular}{|c|c|c|c|c|c|}
\hline \multirow{2}{*}{ No. } & \multirow{2}{*}{ Distance } & \multicolumn{4}{|c|}{$(\mathrm{mm})$} \\
\hline & & Min & Max & Mean & $\mathrm{s}^{2}$ \\
\hline SL & Standard length & 75.72 & 76.81 & 76.46 & 0.08 \\
\hline 1 & Snout - occiput & 15.97 & 16.51 & 16.17 & 0.02 \\
\hline 2 & Occiput - first dorsal-fin spine & 9.01 & 9.92 & 9.50 & 0.06 \\
\hline 3 & Base of first dorsal fin & 24.12 & 25.21 & 24.59 & 0.10 \\
\hline 4 & Base of second dorsal fin & 16.12 & 17.24 & 16.77 & 0.07 \\
\hline 5 & $\begin{array}{l}\text { Last dorsal fin ray - dorsal caudal } \\
\text { flexure }\end{array}$ & 10.74 & 12.03 & 11.48 & 0.10 \\
\hline 6 & Depth at caudal flexure & 9.57 & 9.83 & 9.70 & 0.01 \\
\hline 7 & $\begin{array}{l}\text { Last anal-fin ray - ventral caudal } \\
\text { flexure }\end{array}$ & 15.61 & 17.29 & 16.48 & 0.17 \\
\hline 8 & Base of anal fin & 12.06 & 13.56 & 12.55 & 0.14 \\
\hline 9 & $\begin{array}{l}\text { Mid-point between pelvic-fin bases - } \\
\text { first anal-fin ray }\end{array}$ & 25.46 & 26.34 & 25.87 & 0.07 \\
\hline 10 & $\begin{array}{l}\text { Branchiostegal connection - midpoint } \\
\text { between pelvic-fin bases }\end{array}$ & 14.54 & 15.58 & 15.19 & 0.09 \\
\hline 11 & Snout - branchiostegal connection & 7.04 & 8.08 & 7.51 & 0.06 \\
\hline 12 & Branchiostegal connection - occiput & 13.40 & 13.86 & 13.57 & 0.02 \\
\hline 13 & $\begin{array}{l}\text { Branchiostegal connection - first } \\
\text { dorsal-fin spine }\end{array}$ & 20.08 & 21.61 & 20.90 & 0.12 \\
\hline 14 & $\begin{array}{l}\text { Occiput - mid-point between pelvic } \\
\text { fin bases }\end{array}$ & 15.48 & 16.49 & 16.20 & 0.07 \\
\hline 15 & $\begin{array}{l}\text { Mid-point between pelvic fin bases - } \\
\text { first dorsal-fin spine }\end{array}$ & 15.07 & 15.89 & 15.52 & 0.07 \\
\hline 16 & $\begin{array}{l}\text { Mid-point between pelvic fin bases - } \\
\text { second dorsal-fin origin }\end{array}$ & 27.80 & 29.81 & 28.43 & 0.21 \\
\hline 17 & First dorsal fin spine - anal-fin origin & 28.72 & 29.82 & 29.19 & 0.08 \\
\hline 18 & $\begin{array}{l}\text { Anal-fin origin - second dorsal-fin } \\
\text { origin }\end{array}$ & 14.02 & 15.31 & 14.42 & 0.11 \\
\hline 19 & Anal-fin origin - last dorsal-fin ray & 19.09 & 20.73 & 19.79 & 0.17 \\
\hline 20 & $\begin{array}{l}\text { Second dorsal-fin origin - last anal- } \\
\text { fin ray }\end{array}$ & 17.78 & 18.50 & 18.09 & 0.04 \\
\hline 21 & Last dorsal-fin ray - last anal-fin ray & 9.53 & 10.57 & 10.01 & 0.10 \\
\hline 22 & $\begin{array}{l}\text { Last anal-fin ray - dorsal caudal } \\
\text { flexure }\end{array}$ & 17.70 & 19.86 & 19.26 & 0.24 \\
\hline 23 & $\begin{array}{l}\text { Last dorsal-fin ray - ventral caudal } \\
\text { flexure }\end{array}$ & 14.44 & 15.78 & 15.13 & 0.13 \\
\hline 24 & Snout - anterior margin of eye & 5.57 & 6.78 & 6.40 & 0.07 \\
\hline 25 & Eye width & 4.15 & 4.44 & 4.26 & 0.01 \\
\hline 26 & Snout - opercle spine tip & 18.01 & 18.55 & 18.28 & 0.02 \\
\hline 27 & Anterior internasal width & 2.72 & 3.18 & 3.03 & 0.01 \\
\hline 28 & Posterior internasal width & 3.00 & 3.37 & 3.16 & 0.01 \\
\hline 29 & Interorbital width & 2.41 & 2.76 & 2.60 & 0.01 \\
\hline 30 & Gape width & 5.58 & 6.02 & 5.77 & 0.01 \\
\hline 31 & Outerpelvic base width & 7.35 & 7.73 & 7.47 & 0.01 \\
\hline 32 & Caudal-fin length & 13.43 & 14.89 & 14.25 & 0.29 \\
\hline
\end{tabular}




\section{FIGURES}

Figure 1. Distribution records of E. osburni in West Virginia from 1931 - 2015 (WVDNR unpublished data).

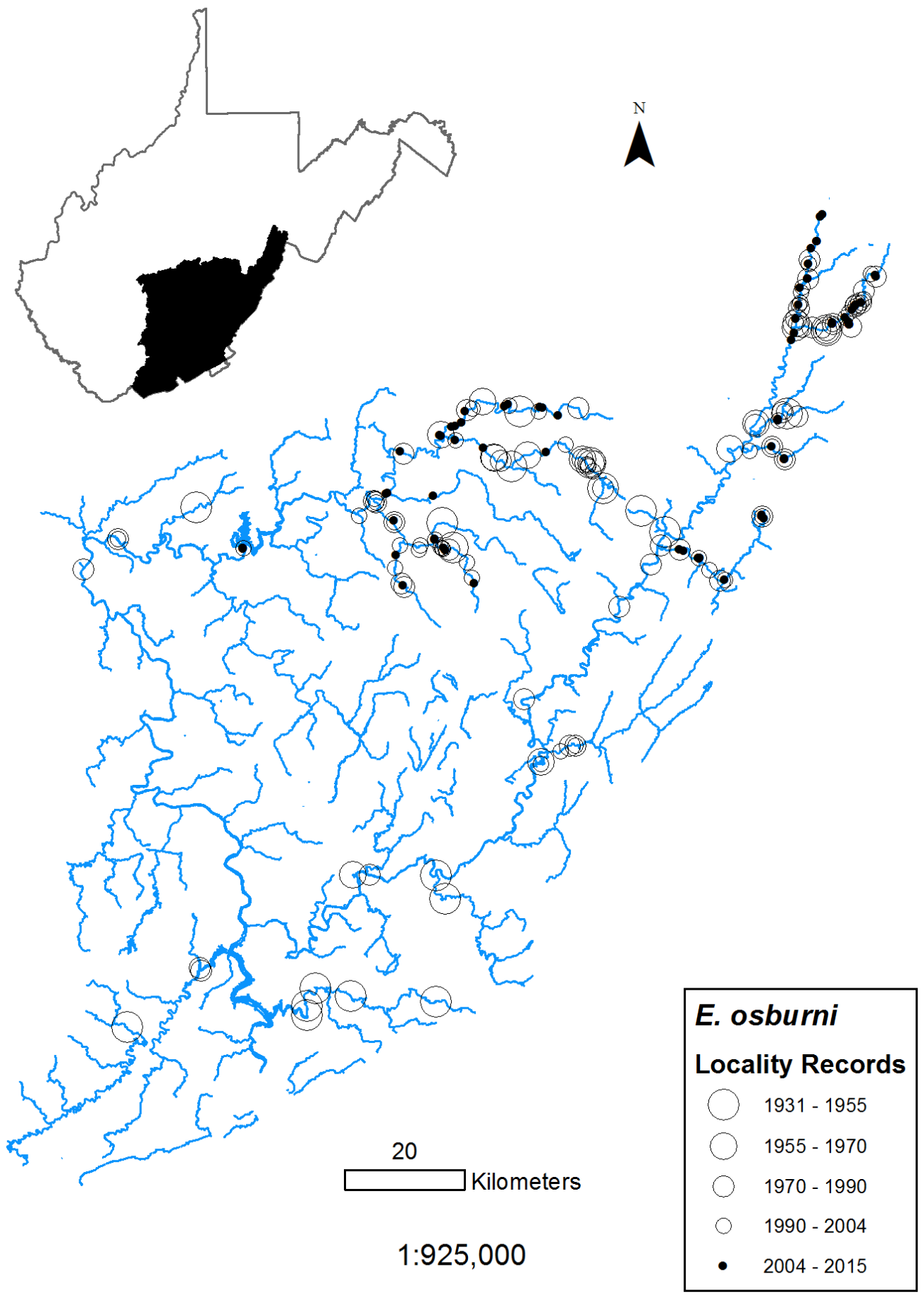


Figure 2. Distribution records of E. variatum morphometrically identified in the New River drainage, West Virginia from 1982 - 2014 (WVDNR unpublished data). These data do not include genetic detection of $E$. variatum alleles of the current study.

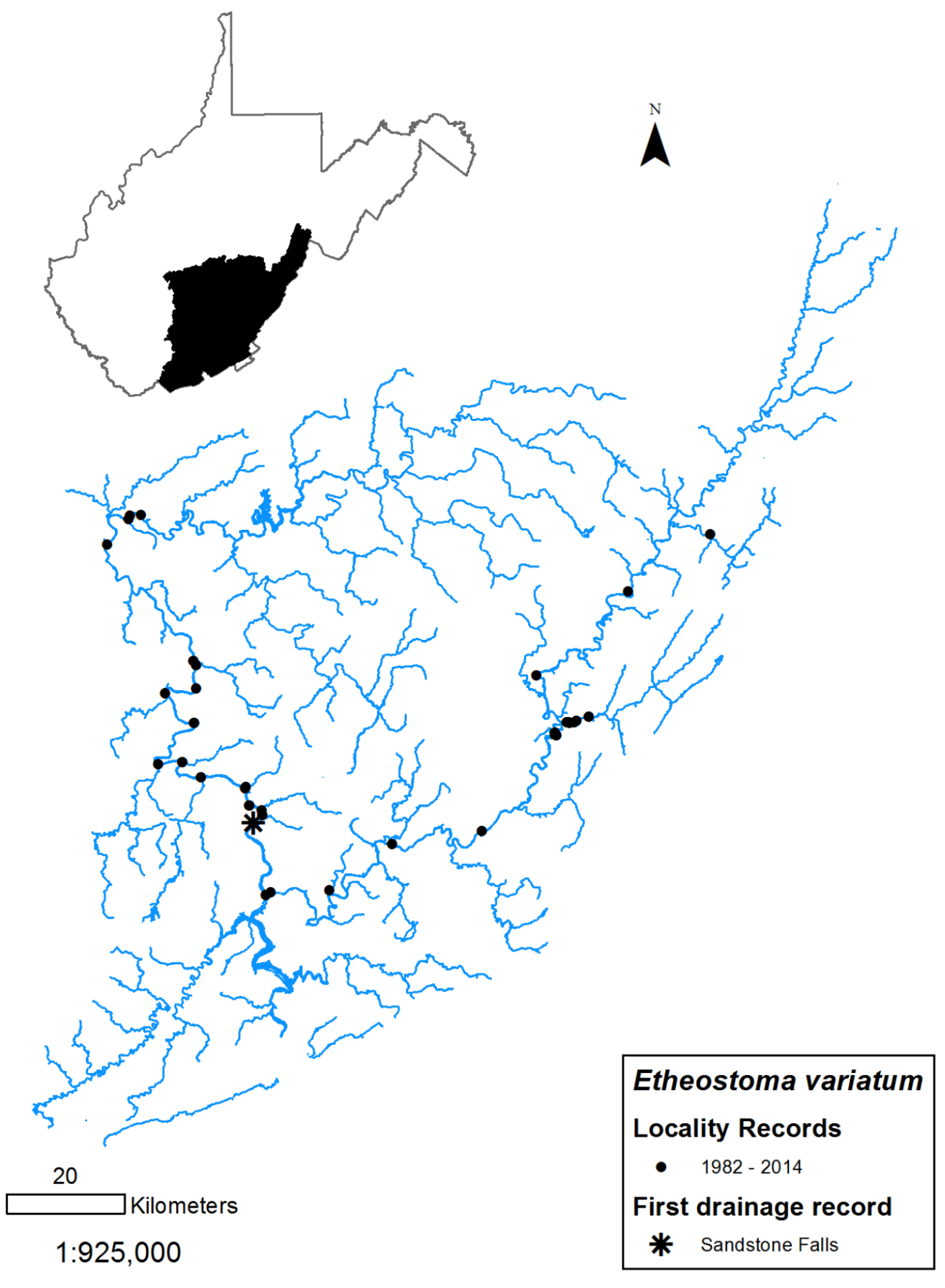


Figure 3. Collection sites for materials used in this study. Site labels correspond with Table 1.

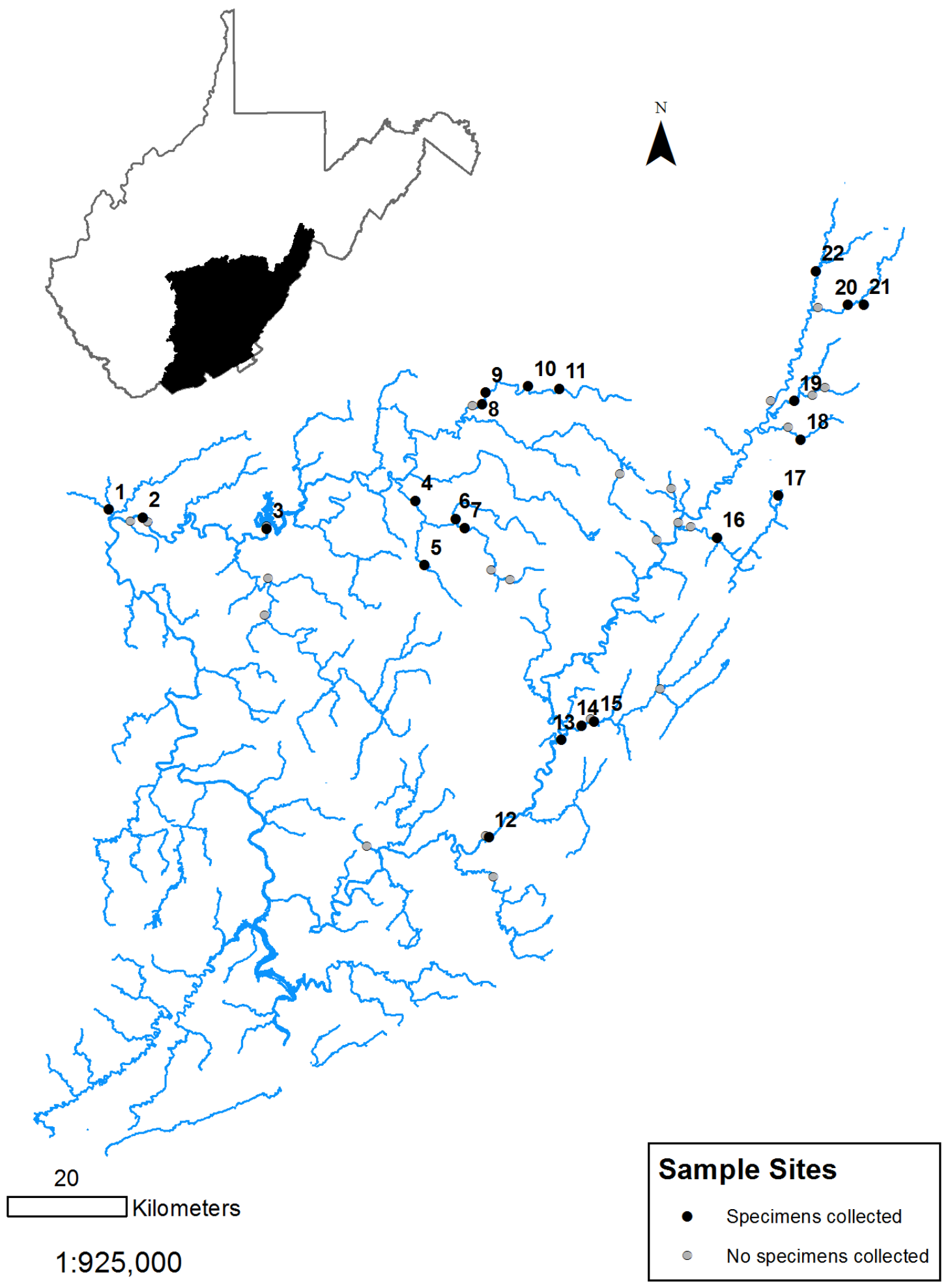


Figure 4. Photograph depicting typical cephalic squamation of Etheostoma variatum. One scale patch is shown on the opercle. Two scale patches are shown in the supraopercular region. Etheostoma osburni $\mathrm{X}$ Etheostoma variatum may possess any or none of these scale patches.

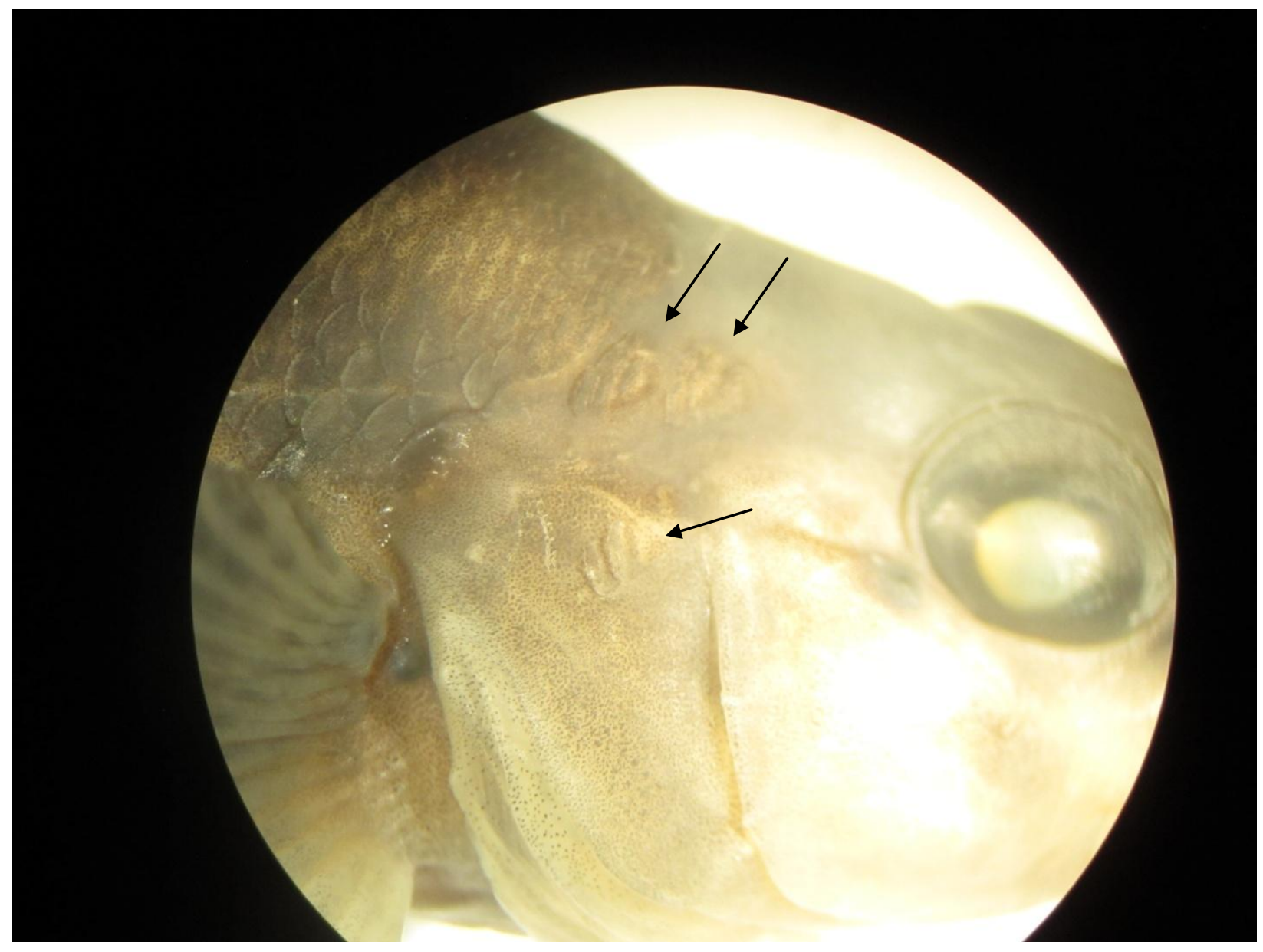


Figure 5. STRUCTURE diagram depicting posterior probability of assignment (vertical axis) for all individuals collected at $\mathrm{K}=2$. Samples $1-10$ are comprised of pure E. osburni. Horizontal axis is sample location number.

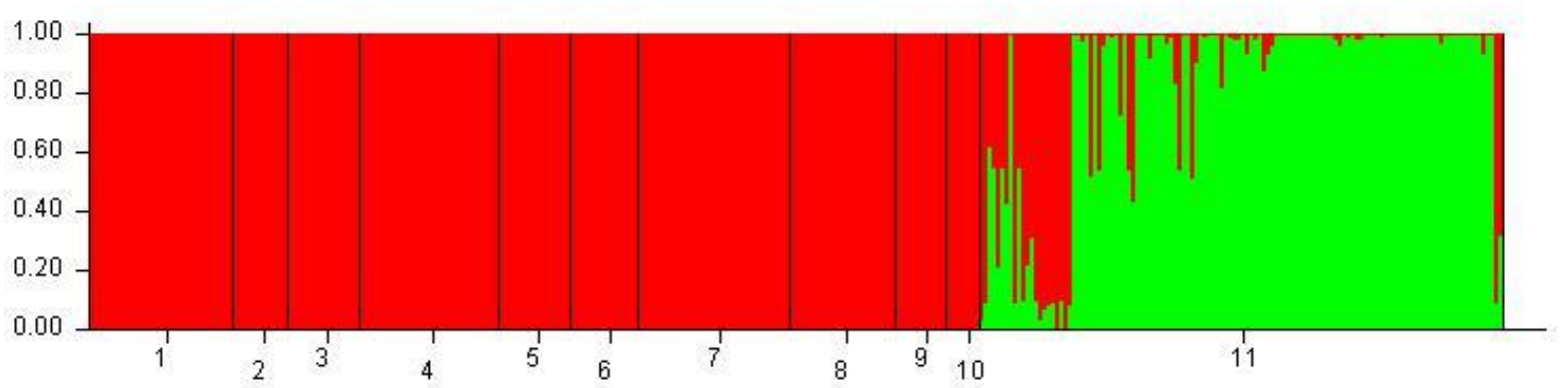

Figure 6. STRUCTURE diagram depicting posterior probability of assignment (vertical axis) for $E$. osburni at $\mathrm{K}=2$. Samples $3-8$ are from the Gauley River drainage. Samples 1, 2, 9, and 10 are from the Greenbrier River drainage. Horizontal axis is sample location number.

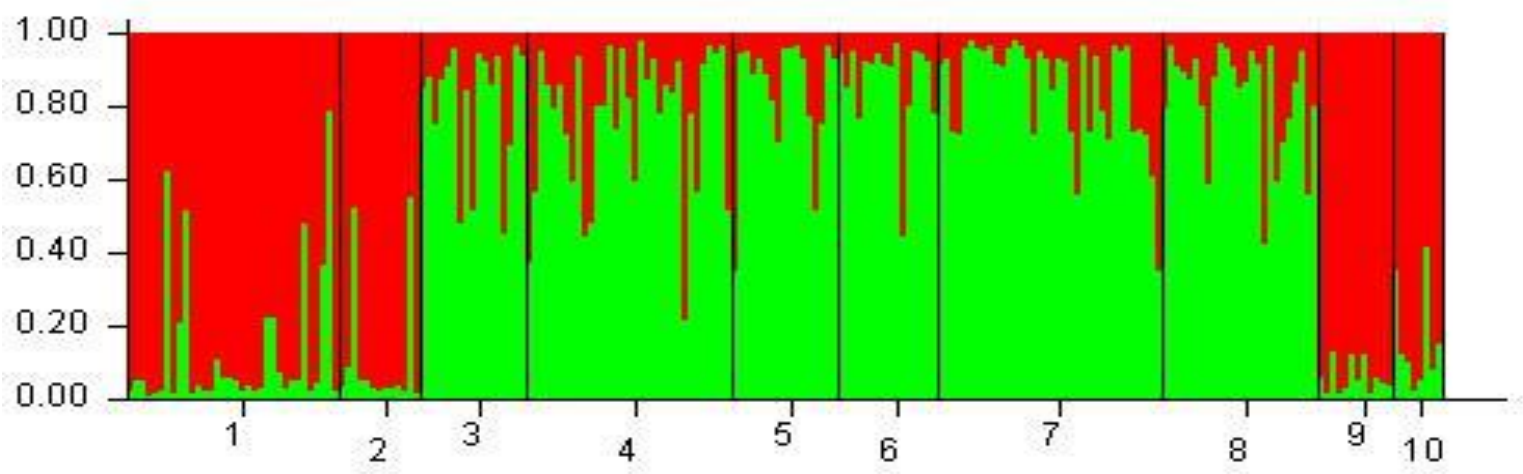


Figure 7. Posterior probability of assignment (vertical axis) to six classifications: E. osburni, E. variatum, F1 hybrid, F2 hybrid, backcross with E. osburni, and backcross with E. variatum. Site numbers (horizontal axis) correspond to Table 1. Elevation in each drainage increases with distance from the dashed line. The relative location of Summersville Dam is indicated.

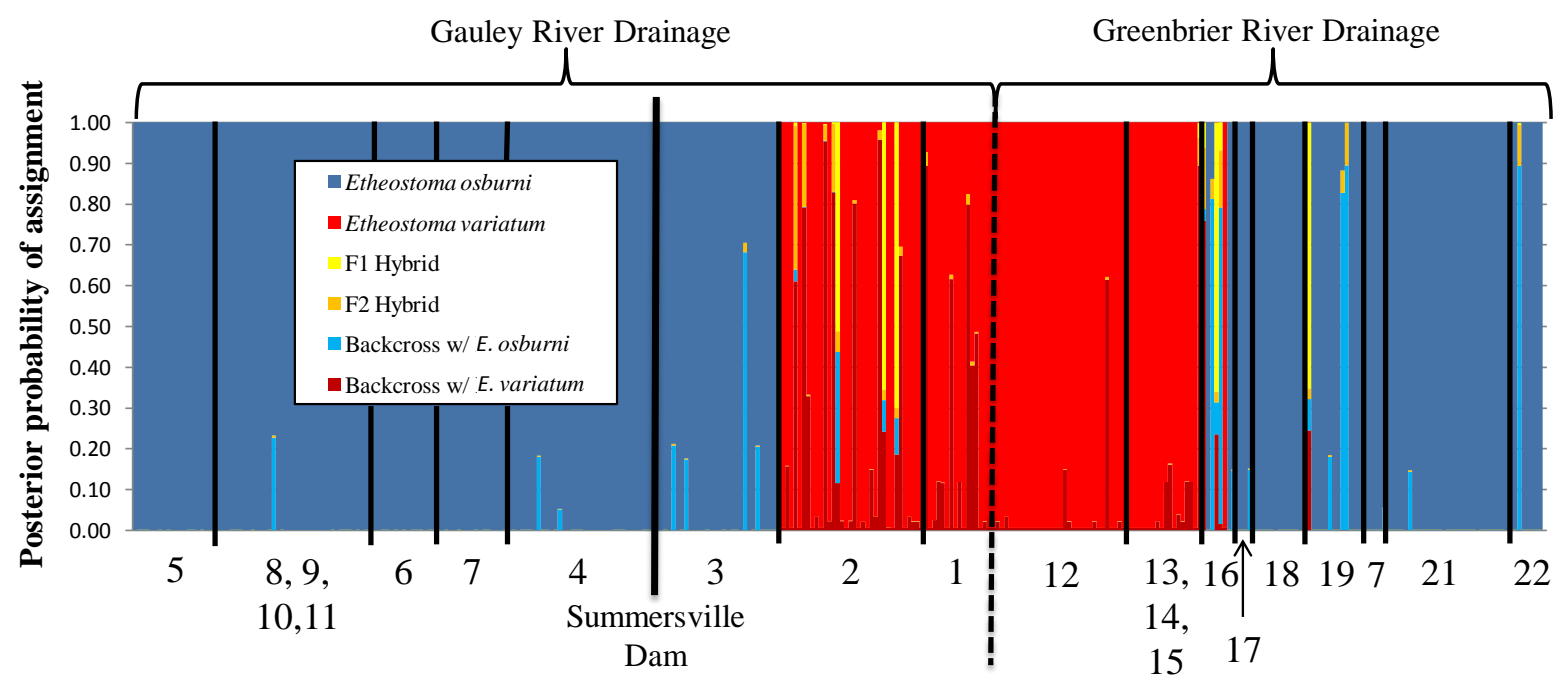


Figure 8. Etheostoma variatum alleles detected during this study (open diamonds). Solid circles indicate the presence of pure E. osburni in a sample. Open circles indicate the collection location of first generation (F1) hybrids of E. osburni X E. variatum. The proportion of E. variatum alleles within each sample where E. variatum alleles were detected is labeled.

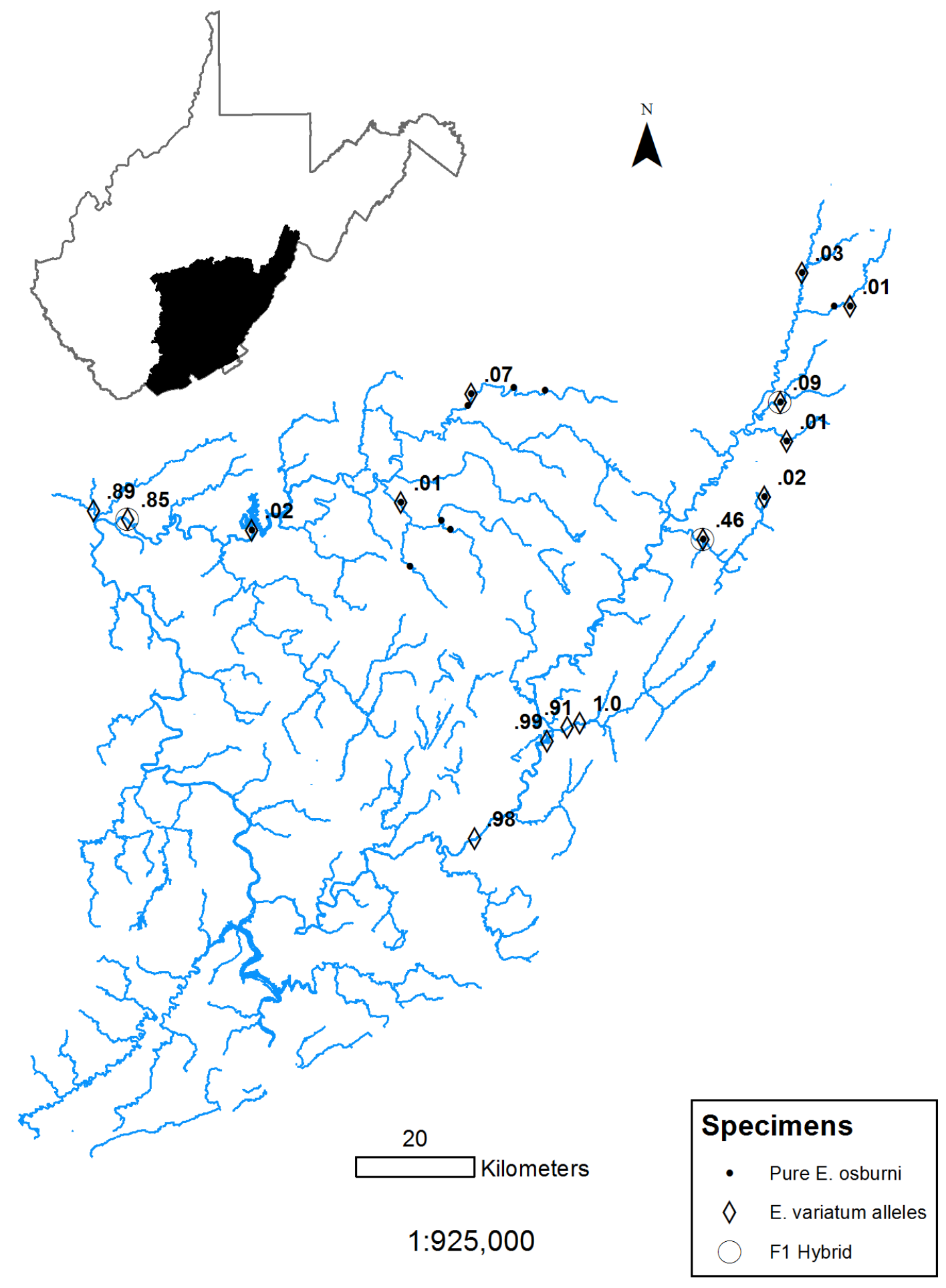


Figure 9. Etheostoma osburni X Etheostoma variatum. $71 \mathrm{~mm}$ SL male, Deer Creek (Site 19), Pocahontas Co., WV, 7 March 2017. Photograph by Dr. Stuart A. Welsh.

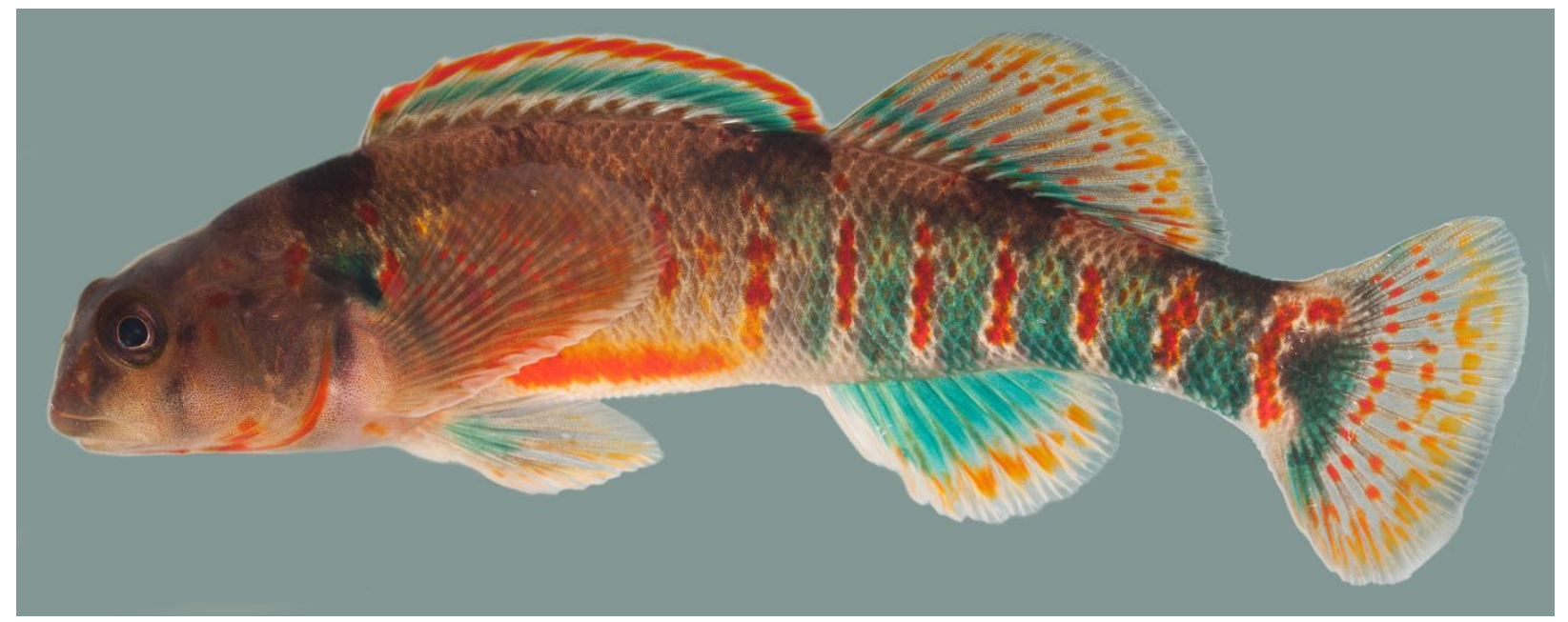

Figure 10. Etheostoma osburni X Etheostoma variatum. $68 \mathrm{~mm}$ SL female, Deer Creek (Site 19), Pocahontas Co., WV, 7 March 2017. This individual was gravid at the time of collection. Photograph by Dr. Stuart A. Welsh.

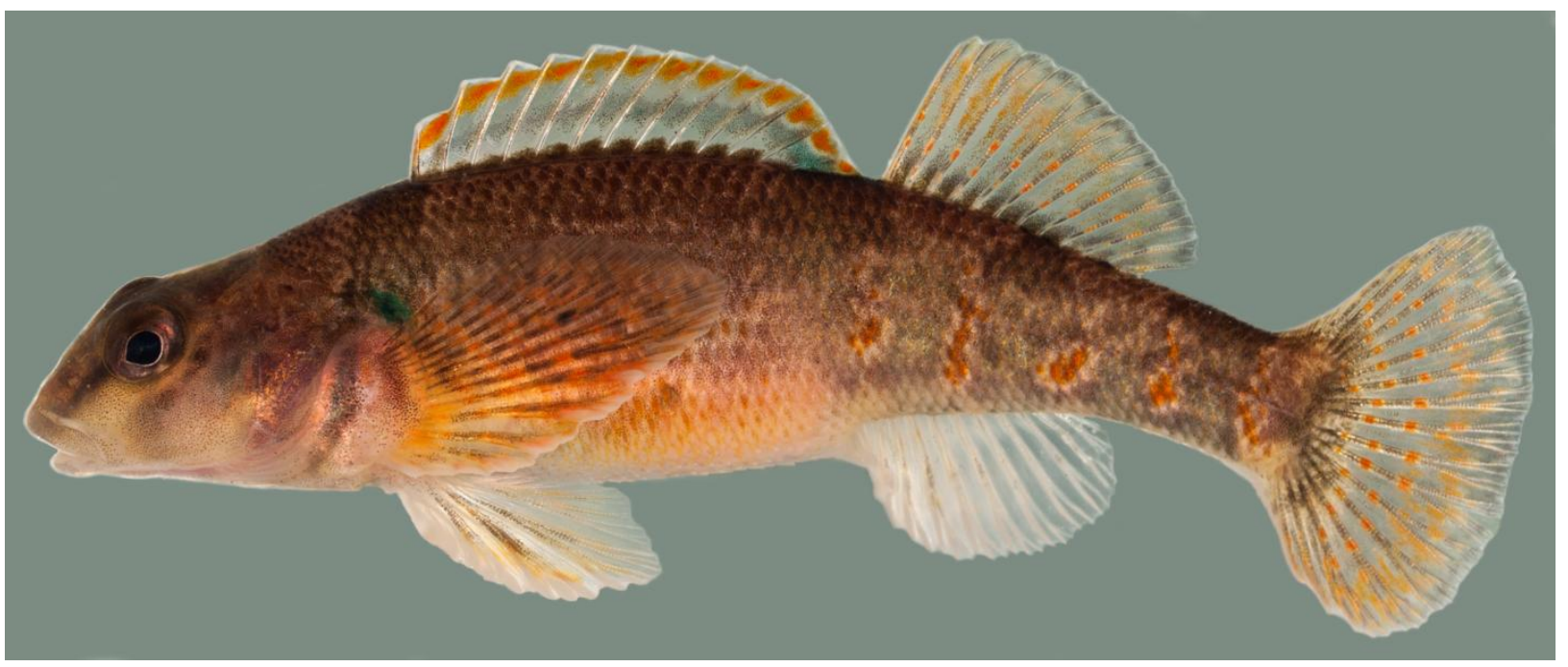


Figure 11. Etheostoma osburni. 78 mm SL male, East Fork Greenbrier River, Pocahontas Co., WV, 4 April 2016. Photograph by Dr. Stuart A. Welsh.

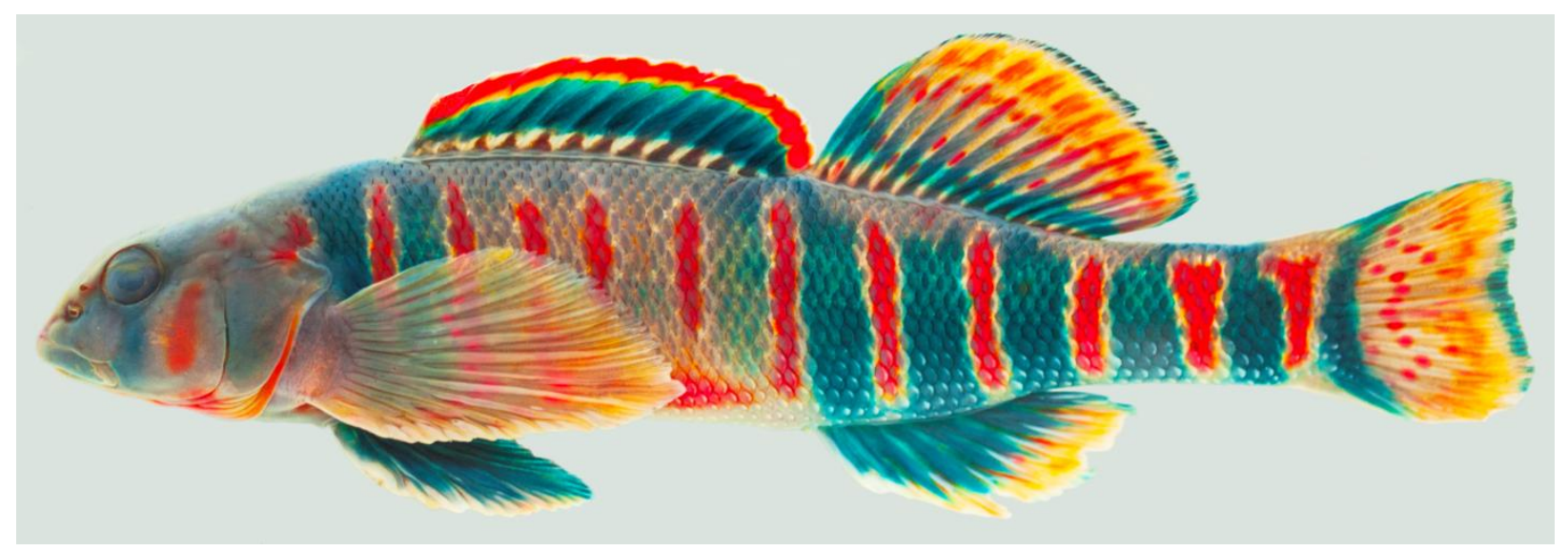

Figure 12. Etheostoma osburni. $65 \mathrm{~mm}$ SL female, Little River East Fork Greenbrier River, Pocahontas Co., WV, 28 March 2017. Photograph by Dr. Stuart A. Welsh.

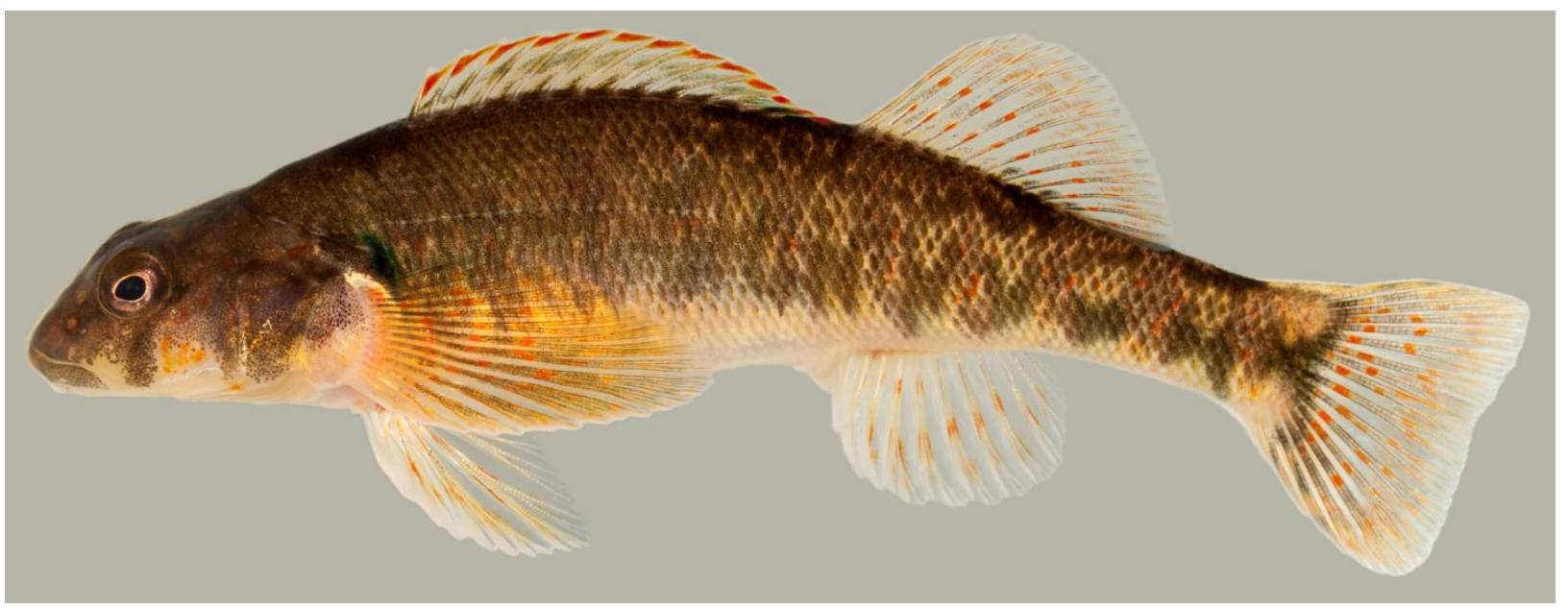


Figure 13. Etheostoma variatum. $66 \mathrm{~mm}$ SL male, Twentymile Creek, Nicholas Co., WV, 19 April 2017. Photograph by Dr. Stuart A. Welsh.

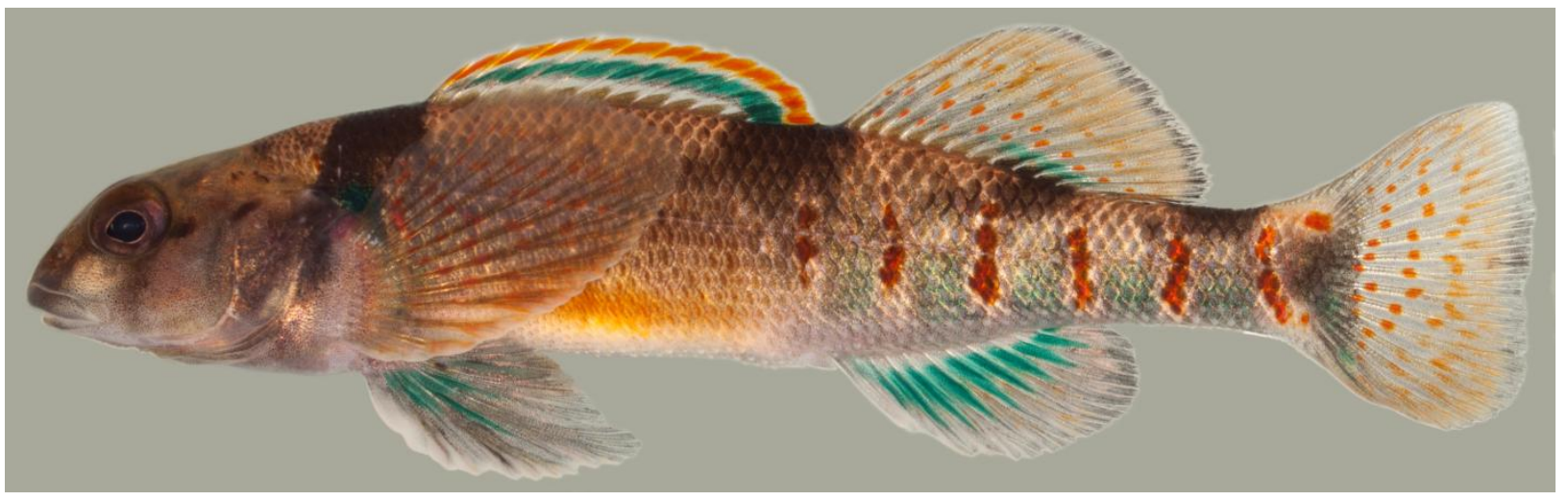

Figure 14. Etheostoma variatum. $57 \mathrm{~mm}$ SL female, Twentymile Creek, Nicholas Co., WV, 19 April 2017. Photograph by Dr. Stuart A. Welsh.

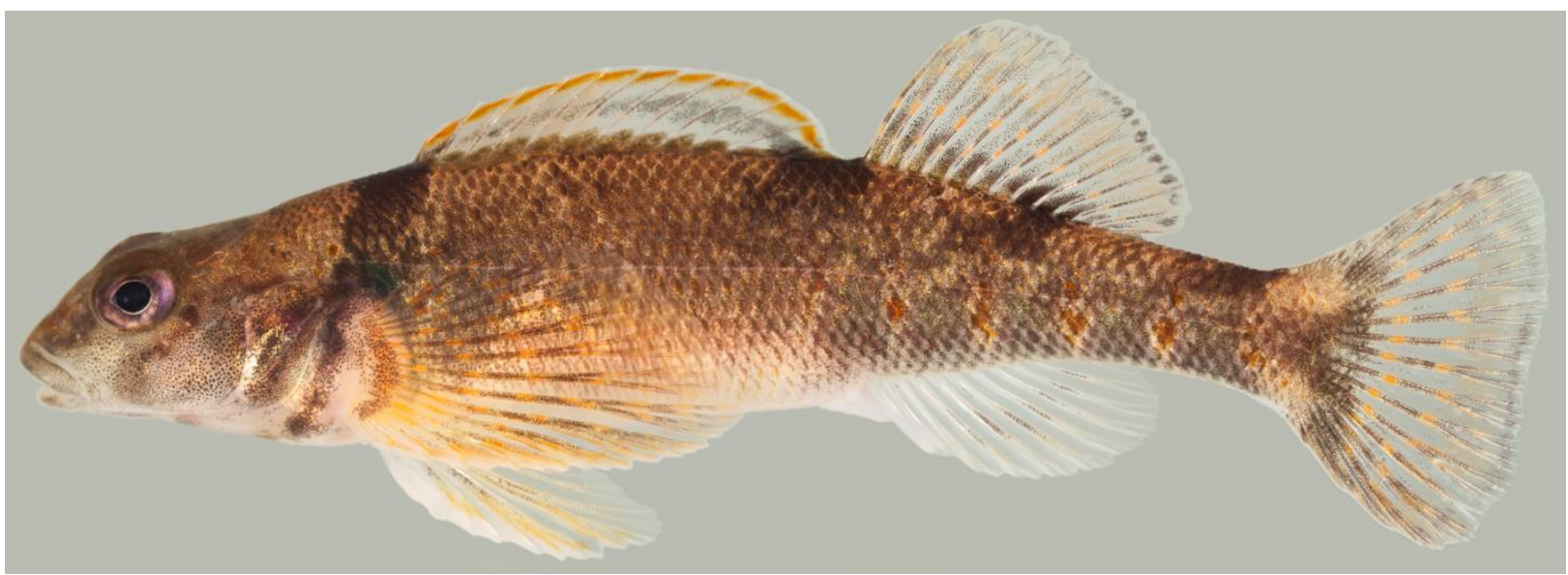


Figure 15. Box truss network comprised of 23 distances for morphometric analysis of E. osburni and E. osburni X E. variatum. Numeric labels correspond to Table 5.

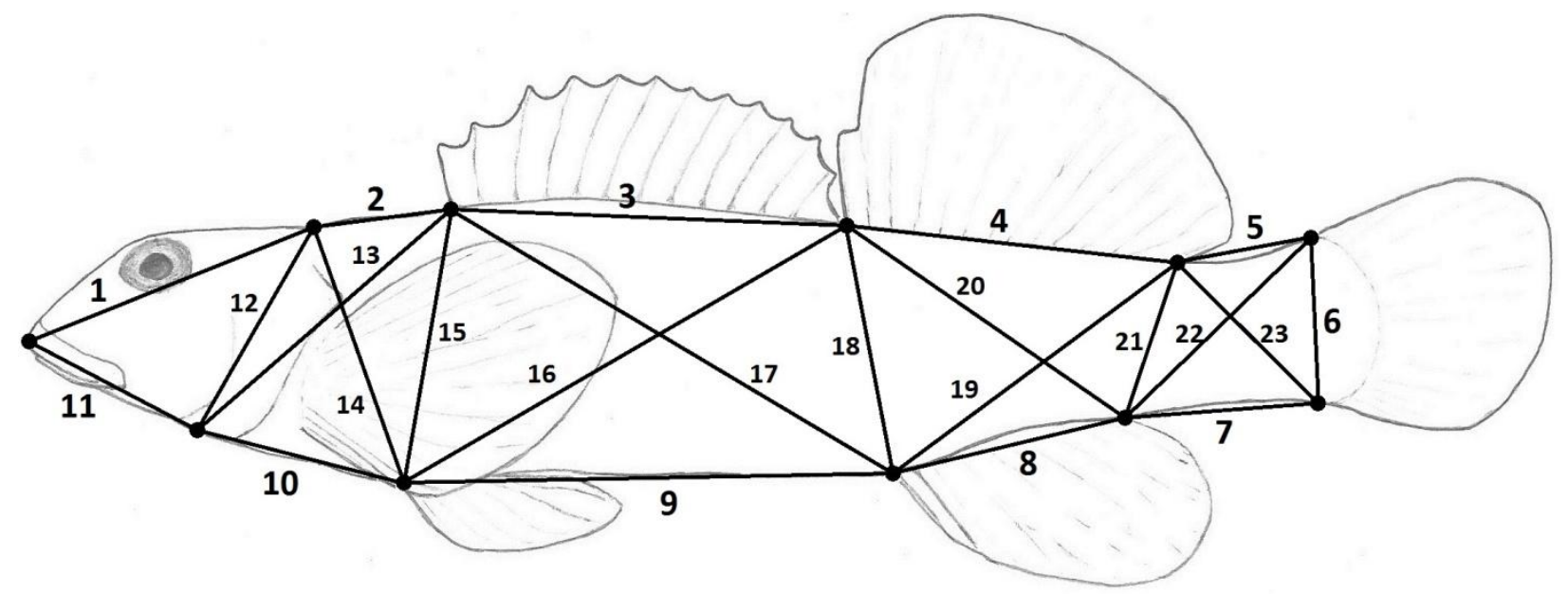

Figure 16. Supplemental distances for morphometric analysis of E. osburni and E. osburni X E. variatum. Labels correspond to Table 5.
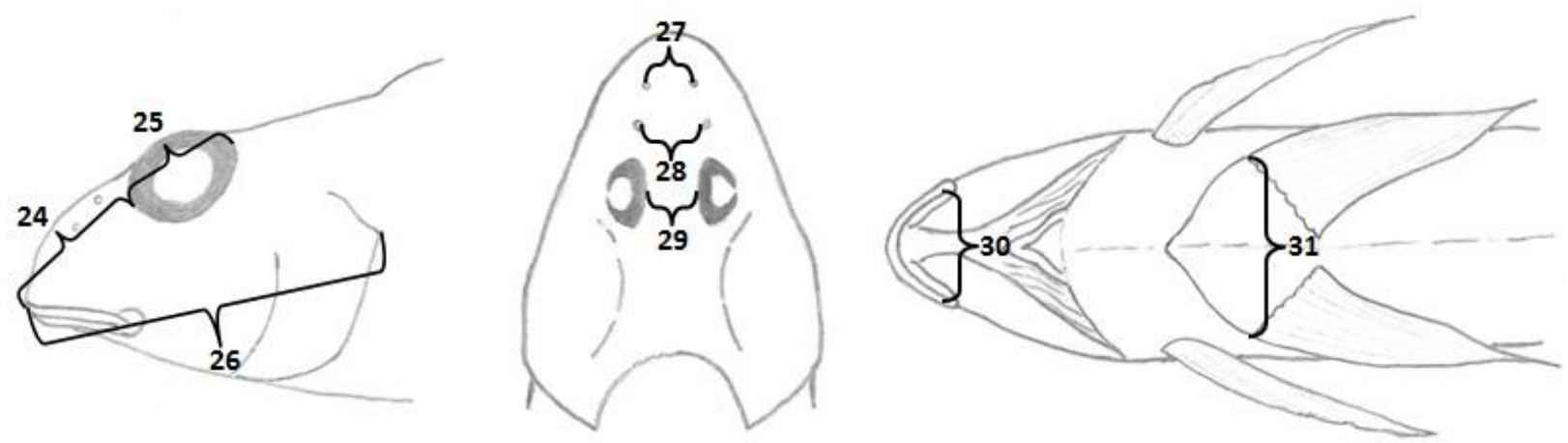
Figure 17. Neighbor-joining tree based on 1000 generated trees. Values presented are percents of 1000 generated trees that group the samples together. The drainage to which each sample belongs is labeled in parentheses. Members of each sample are described in detail in Table 4.

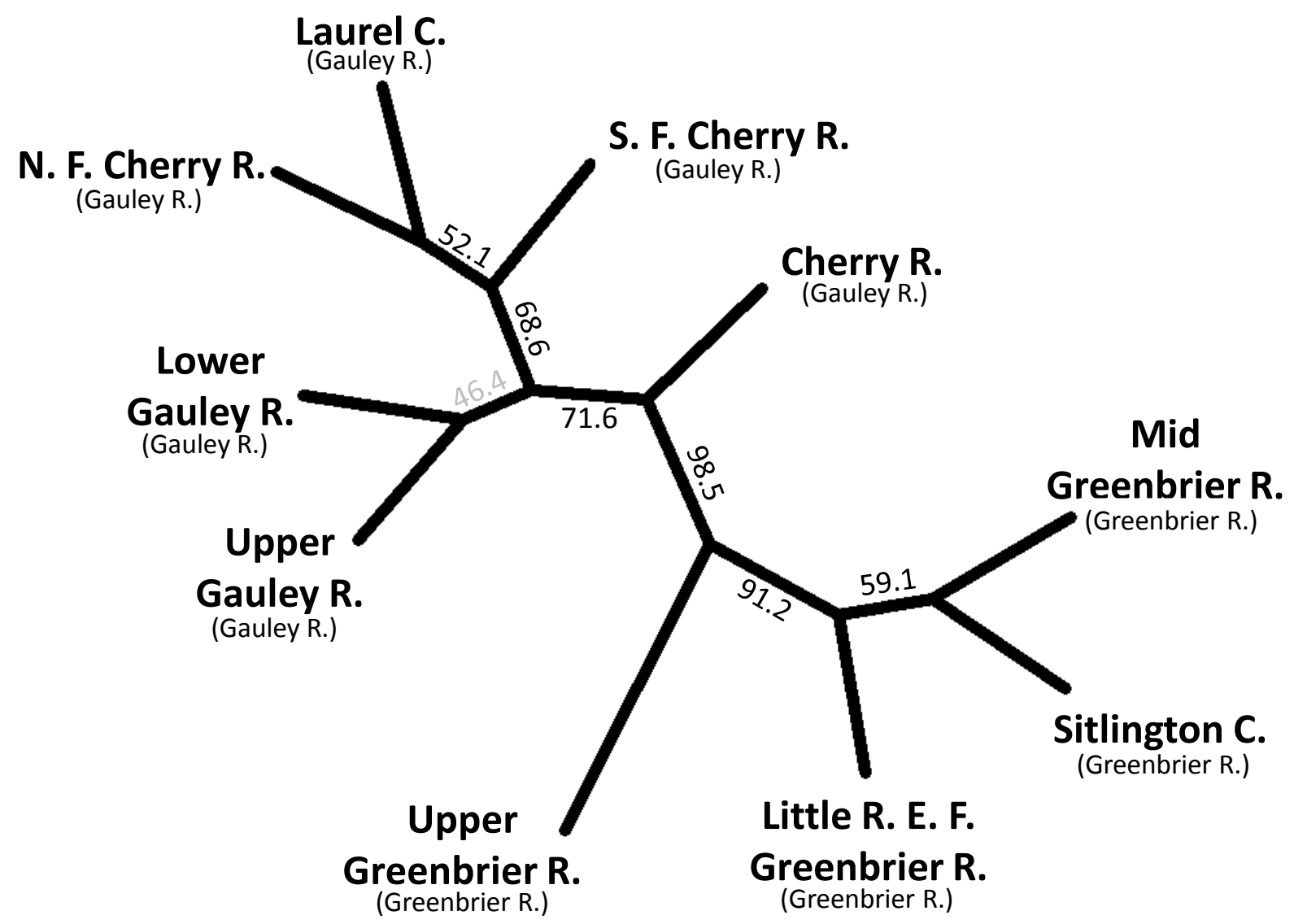


Figure 18. Plots of the sheared second and third principal components (SPC2 and SPC3) that depict shape differences between the Gauley (triangles) and Greenbrier (circles) populations of E. osburni.
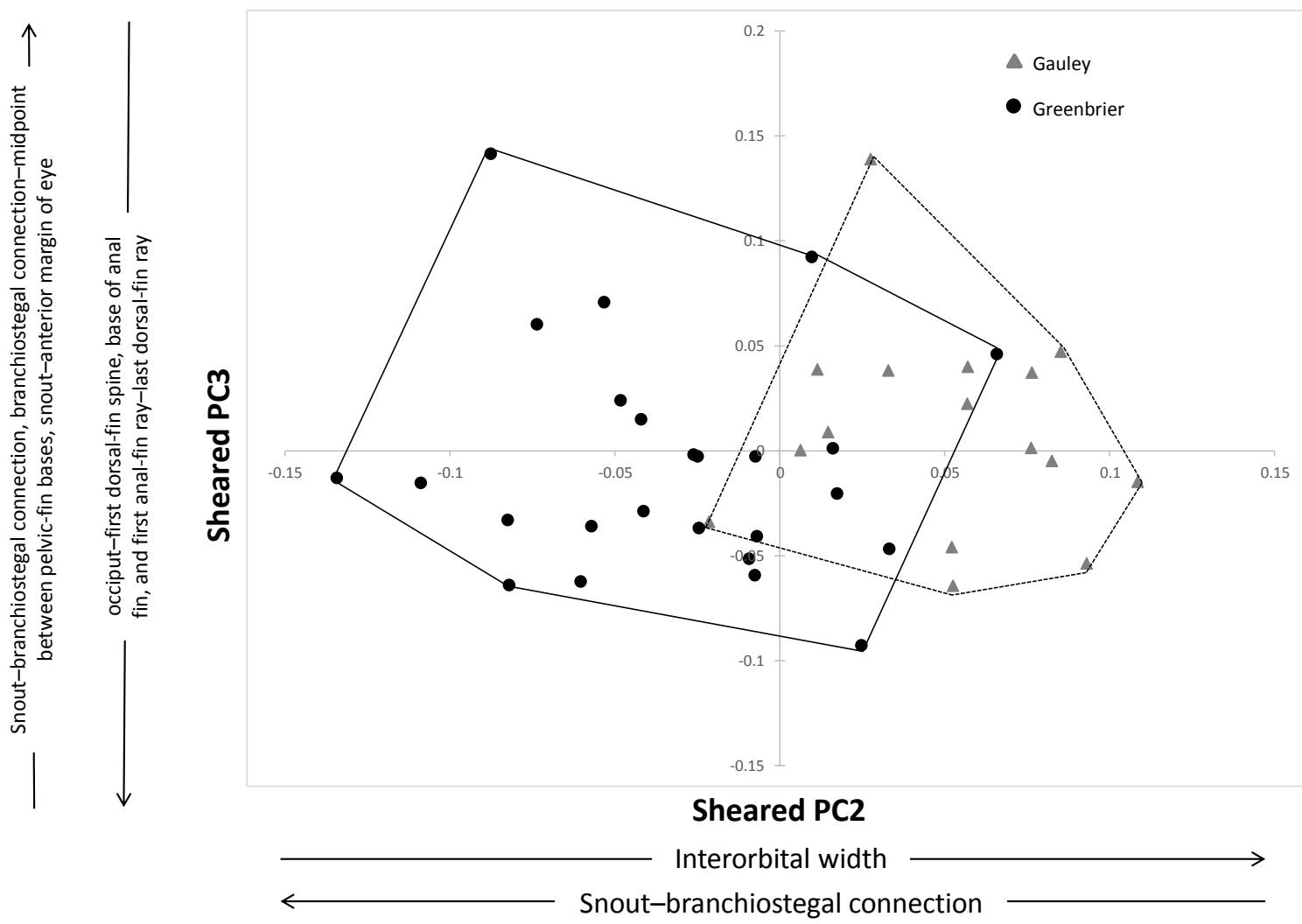


\section{APPENDICES}

Appendix 1. Posterior probability of assignment to six species/hybrid classifications. Site numbers that are listed correspond to Table 1. Each row represents an individual $(\mathrm{n}=335)$.

\begin{tabular}{|c|c|c|c|c|c|c|}
\hline Site & E. osburni & E. variatum & $\begin{array}{c}\text { F1 } \\
\text { Hybrid }\end{array}$ & $\begin{array}{c}\text { F2 } \\
\text { Hybrid }\end{array}$ & $\begin{array}{c}\text { Backcross w/ } \\
\text { E. osburni }\end{array}$ & $\begin{array}{c}\text { Backcross w/ } \\
\text { E. variatum }\end{array}$ \\
\hline 5 & 0.999 & 0.000 & 0.000 & 0.000 & 0.001 & 0.000 \\
\hline 5 & 0.999 & 0.000 & 0.000 & 0.000 & 0.002 & 0.000 \\
\hline 5 & 0.999 & 0.000 & 0.000 & 0.000 & 0.001 & 0.000 \\
\hline 5 & 0.999 & 0.000 & 0.000 & 0.000 & 0.001 & 0.000 \\
\hline 5 & 0.999 & 0.000 & 0.000 & 0.000 & 0.001 & 0.000 \\
\hline 5 & 0.999 & 0.000 & 0.000 & 0.000 & 0.001 & 0.000 \\
\hline 5 & 0.999 & 0.000 & 0.000 & 0.000 & 0.001 & 0.000 \\
\hline 5 & 0.999 & 0.000 & 0.000 & 0.000 & 0.001 & 0.000 \\
\hline 5 & 0.999 & 0.000 & 0.000 & 0.000 & 0.002 & 0.000 \\
\hline 5 & 0.999 & 0.000 & 0.000 & 0.000 & 0.001 & 0.000 \\
\hline 5 & 0.999 & 0.000 & 0.000 & 0.000 & 0.001 & 0.000 \\
\hline 5 & 0.999 & 0.000 & 0.000 & 0.000 & 0.001 & 0.000 \\
\hline 5 & 0.999 & 0.000 & 0.000 & 0.000 & 0.001 & 0.000 \\
\hline 5 & 0.999 & 0.000 & 0.000 & 0.000 & 0.001 & 0.000 \\
\hline 5 & 0.999 & 0.000 & 0.000 & 0.000 & 0.001 & 0.000 \\
\hline 5 & 0.999 & 0.000 & 0.000 & 0.000 & 0.001 & 0.000 \\
\hline 5 & 0.999 & 0.000 & 0.000 & 0.000 & 0.001 & 0.000 \\
\hline $8,9,10,11$ & 0.999 & 0.000 & 0.000 & 0.000 & 0.001 & 0.000 \\
\hline $8,9,10,11$ & 0.999 & 0.000 & 0.000 & 0.000 & 0.001 & 0.000 \\
\hline $8,9,10,11$ & 0.999 & 0.000 & 0.000 & 0.000 & 0.001 & 0.000 \\
\hline $8,9,10,11$ & 0.999 & 0.000 & 0.000 & 0.000 & 0.001 & 0.000 \\
\hline $8,9,10,11$ & 0.999 & 0.000 & 0.000 & 0.000 & 0.001 & 0.000 \\
\hline $8,9,10,11$ & 0.999 & 0.000 & 0.000 & 0.000 & 0.001 & 0.000 \\
\hline $8,9,10,11$ & 0.999 & 0.000 & 0.000 & 0.000 & 0.001 & 0.000 \\
\hline $8,9,10,11$ & 0.999 & 0.000 & 0.000 & 0.000 & 0.001 & 0.000 \\
\hline $8,9,10,11$ & 0.999 & 0.000 & 0.000 & 0.000 & 0.001 & 0.000 \\
\hline $8,9,10,11$ & 0.999 & 0.000 & 0.000 & 0.000 & 0.001 & 0.000 \\
\hline $8,9,10,11$ & 0.999 & 0.000 & 0.000 & 0.000 & 0.001 & 0.000 \\
\hline $8,9,10,11$ & 0.999 & 0.000 & 0.000 & 0.000 & 0.001 & 0.000 \\
\hline $8,9,10,11$ & 0.999 & 0.000 & 0.000 & 0.000 & 0.001 & 0.000 \\
\hline $8,9,10,11$ & 0.999 & 0.000 & 0.000 & 0.000 & 0.001 & 0.000 \\
\hline $8,9,10,11$ & 0.999 & 0.000 & 0.000 & 0.000 & 0.001 & 0.000 \\
\hline $8,9,10,11$ & 0.999 & 0.000 & 0.000 & 0.000 & 0.001 & 0.000 \\
\hline $8,9,10,11$ & 0.767 & 0.000 & 0.000 & 0.006 & 0.227 & 0.000 \\
\hline $8,9,10,11$ & 0.999 & 0.000 & 0.000 & 0.000 & 0.001 & 0.000 \\
\hline $8,9,10,11$ & 0.999 & 0.000 & 0.000 & 0.000 & 0.001 & 0.000 \\
\hline
\end{tabular}




\begin{tabular}{|c|c|c|c|c|c|c|}
\hline Site & E. osburni & E. variatum & $\begin{array}{c}\text { F1 } \\
\text { Hybrid }\end{array}$ & $\begin{array}{c}\text { F2 } \\
\text { Hybrid }\end{array}$ & $\begin{array}{c}\text { Backcross w/ } \\
\text { E. osburni }\end{array}$ & $\begin{array}{c}\text { Backcross w/ } \\
\text { E. variatum }\end{array}$ \\
\hline $8,9,10,11$ & 0.999 & 0.000 & 0.000 & 0.000 & 0.001 & 0.000 \\
\hline $8,9,10,11$ & 0.999 & 0.000 & 0.000 & 0.000 & 0.001 & 0.000 \\
\hline $8,9,10,11$ & 0.999 & 0.000 & 0.000 & 0.000 & 0.001 & 0.000 \\
\hline $8,9,10,11$ & 0.999 & 0.000 & 0.000 & 0.000 & 0.001 & 0.000 \\
\hline $8,9,10,11$ & 0.999 & 0.000 & 0.000 & 0.000 & 0.001 & 0.000 \\
\hline $8,9,10,11$ & 0.999 & 0.000 & 0.000 & 0.000 & 0.001 & 0.000 \\
\hline $8,9,10,11$ & 0.999 & 0.000 & 0.000 & 0.000 & 0.001 & 0.000 \\
\hline $8,9,10,11$ & 0.999 & 0.000 & 0.000 & 0.000 & 0.001 & 0.000 \\
\hline $8,9,10,11$ & 0.999 & 0.000 & 0.000 & 0.000 & 0.001 & 0.000 \\
\hline $8,9,10,11$ & 0.999 & 0.000 & 0.000 & 0.000 & 0.001 & 0.000 \\
\hline $8,9,10,11$ & 0.999 & 0.000 & 0.000 & 0.000 & 0.001 & 0.000 \\
\hline $8,9,10,11$ & 0.999 & 0.000 & 0.000 & 0.000 & 0.001 & 0.000 \\
\hline $8,9,10,11$ & 0.999 & 0.000 & 0.000 & 0.000 & 0.001 & 0.000 \\
\hline $8,9,10,11$ & 0.999 & 0.000 & 0.000 & 0.000 & 0.001 & 0.000 \\
\hline $8,9,10,11$ & 0.999 & 0.000 & 0.000 & 0.000 & 0.001 & 0.000 \\
\hline $8,9,10,11$ & 0.999 & 0.000 & 0.000 & 0.000 & 0.001 & 0.000 \\
\hline $8,9,10,11$ & 0.999 & 0.000 & 0.000 & 0.000 & 0.001 & 0.000 \\
\hline $8,9,10,11$ & 0.999 & 0.000 & 0.000 & 0.000 & 0.001 & 0.000 \\
\hline 6 & 0.999 & 0.000 & 0.000 & 0.000 & 0.001 & 0.000 \\
\hline 6 & 0.999 & 0.000 & 0.000 & 0.000 & 0.001 & 0.000 \\
\hline 6 & 0.999 & 0.000 & 0.000 & 0.000 & 0.001 & 0.000 \\
\hline 6 & 0.999 & 0.000 & 0.000 & 0.000 & 0.001 & 0.000 \\
\hline 6 & 0.999 & 0.000 & 0.000 & 0.000 & 0.001 & 0.000 \\
\hline 6 & 0.999 & 0.000 & 0.000 & 0.000 & 0.001 & 0.000 \\
\hline 6 & 0.999 & 0.000 & 0.000 & 0.000 & 0.001 & 0.000 \\
\hline 6 & 0.999 & 0.000 & 0.000 & 0.000 & 0.001 & 0.000 \\
\hline 6 & 0.999 & 0.000 & 0.000 & 0.000 & 0.001 & 0.000 \\
\hline 6 & 0.999 & 0.000 & 0.000 & 0.000 & 0.001 & 0.000 \\
\hline 6 & 0.999 & 0.000 & 0.000 & 0.000 & 0.001 & 0.000 \\
\hline 6 & 0.999 & 0.000 & 0.000 & 0.000 & 0.001 & 0.000 \\
\hline 6 & 0.999 & 0.000 & 0.000 & 0.000 & 0.001 & 0.000 \\
\hline 6 & 0.999 & 0.000 & 0.000 & 0.000 & 0.001 & 0.000 \\
\hline 6 & 0.999 & 0.000 & 0.000 & 0.000 & 0.001 & 0.000 \\
\hline 6 & 0.999 & 0.000 & 0.000 & 0.000 & 0.001 & 0.000 \\
\hline 6 & 0.999 & 0.000 & 0.000 & 0.000 & 0.001 & 0.000 \\
\hline 7 & 0.999 & 0.000 & 0.000 & 0.000 & 0.001 & 0.000 \\
\hline 7 & 0.999 & 0.000 & 0.000 & 0.000 & 0.001 & 0.000 \\
\hline 7 & 0.999 & 0.000 & 0.000 & 0.000 & 0.001 & 0.000 \\
\hline 7 & 0.999 & 0.000 & 0.000 & 0.000 & 0.001 & 0.000 \\
\hline 7 & 0.999 & 0.000 & 0.000 & 0.000 & 0.001 & 0.000 \\
\hline 7 & 0.999 & 0.000 & 0.000 & 0.000 & 0.001 & 0.000 \\
\hline 7 & 0.999 & 0.000 & 0.000 & 0.000 & 0.001 & 0.000 \\
\hline 7 & 0.999 & 0.000 & 0.000 & 0.000 & 0.001 & 0.000 \\
\hline
\end{tabular}




\begin{tabular}{|c|c|c|c|c|c|c|}
\hline Site & E. osburni & E. variatum & $\begin{array}{c}\text { F1 } \\
\text { Hybrid }\end{array}$ & $\begin{array}{c}\text { F2 } \\
\text { Hybrid }\end{array}$ & $\begin{array}{c}\text { Backcross w/ } \\
\text { E. osburni }\end{array}$ & $\begin{array}{c}\text { Backcross w/ } \\
\text { E. variatum }\end{array}$ \\
\hline 7 & 0.999 & 0.000 & 0.000 & 0.000 & 0.001 & 0.000 \\
\hline 7 & 0.999 & 0.000 & 0.000 & 0.000 & 0.001 & 0.000 \\
\hline 7 & 0.999 & 0.000 & 0.000 & 0.000 & 0.001 & 0.000 \\
\hline 7 & 0.999 & 0.000 & 0.000 & 0.000 & 0.001 & 0.000 \\
\hline 7 & 0.999 & 0.000 & 0.000 & 0.000 & 0.001 & 0.000 \\
\hline 7 & 0.999 & 0.000 & 0.000 & 0.000 & 0.001 & 0.000 \\
\hline 7 & 0.999 & 0.000 & 0.000 & 0.000 & 0.001 & 0.000 \\
\hline 7 & 0.999 & 0.000 & 0.000 & 0.000 & 0.001 & 0.000 \\
\hline 4 & 0.999 & 0.000 & 0.000 & 0.000 & 0.001 & 0.000 \\
\hline 4 & 0.999 & 0.000 & 0.000 & 0.000 & 0.001 & 0.000 \\
\hline 4 & 0.999 & 0.000 & 0.000 & 0.000 & 0.001 & 0.000 \\
\hline 4 & 0.999 & 0.000 & 0.000 & 0.000 & 0.001 & 0.000 \\
\hline 4 & 0.999 & 0.000 & 0.000 & 0.000 & 0.001 & 0.000 \\
\hline 4 & 0.999 & 0.000 & 0.000 & 0.000 & 0.002 & 0.000 \\
\hline 4 & 0.999 & 0.000 & 0.000 & 0.000 & 0.001 & 0.000 \\
\hline 4 & 0.999 & 0.000 & 0.000 & 0.000 & 0.001 & 0.000 \\
\hline 4 & 0.999 & 0.000 & 0.000 & 0.000 & 0.001 & 0.000 \\
\hline 4 & 0.816 & 0.000 & 0.000 & 0.004 & 0.180 & 0.000 \\
\hline 4 & 0.999 & 0.000 & 0.000 & 0.000 & 0.001 & 0.000 \\
\hline 4 & 0.999 & 0.000 & 0.000 & 0.000 & 0.001 & 0.000 \\
\hline 4 & 0.999 & 0.000 & 0.000 & 0.000 & 0.001 & 0.000 \\
\hline 4 & 0.999 & 0.000 & 0.000 & 0.000 & 0.001 & 0.000 \\
\hline 4 & 0.948 & 0.000 & 0.000 & 0.001 & 0.051 & 0.000 \\
\hline 4 & 0.999 & 0.000 & 0.000 & 0.000 & 0.001 & 0.000 \\
\hline 4 & 0.999 & 0.000 & 0.000 & 0.000 & 0.001 & 0.000 \\
\hline 4 & 0.999 & 0.000 & 0.000 & 0.000 & 0.001 & 0.000 \\
\hline 4 & 0.999 & 0.000 & 0.000 & 0.000 & 0.001 & 0.000 \\
\hline 4 & 0.999 & 0.000 & 0.000 & 0.000 & 0.001 & 0.000 \\
\hline 4 & 0.999 & 0.000 & 0.000 & 0.000 & 0.001 & 0.000 \\
\hline 4 & 0.999 & 0.000 & 0.000 & 0.000 & 0.001 & 0.000 \\
\hline 4 & 0.999 & 0.000 & 0.000 & 0.000 & 0.001 & 0.000 \\
\hline 4 & 0.999 & 0.000 & 0.000 & 0.000 & 0.001 & 0.000 \\
\hline 4 & 0.999 & 0.000 & 0.000 & 0.000 & 0.001 & 0.000 \\
\hline 4 & 0.999 & 0.000 & 0.000 & 0.000 & 0.001 & 0.000 \\
\hline 4 & 0.999 & 0.000 & 0.000 & 0.000 & 0.001 & 0.000 \\
\hline 4 & 0.999 & 0.000 & 0.000 & 0.000 & 0.002 & 0.000 \\
\hline 4 & 0.999 & 0.000 & 0.000 & 0.000 & 0.001 & 0.000 \\
\hline 4 & 0.999 & 0.000 & 0.000 & 0.000 & 0.001 & 0.000 \\
\hline 4 & 0.999 & 0.000 & 0.000 & 0.000 & 0.001 & 0.000 \\
\hline 4 & 0.999 & 0.000 & 0.000 & 0.000 & 0.001 & 0.000 \\
\hline 4 & 0.999 & 0.000 & 0.000 & 0.000 & 0.001 & 0.000 \\
\hline 4 & 0.999 & 0.000 & 0.000 & 0.000 & 0.001 & 0.000 \\
\hline 4 & 0.999 & 0.000 & 0.000 & 0.000 & 0.002 & 0.000 \\
\hline
\end{tabular}




\begin{tabular}{|c|c|c|c|c|c|c|}
\hline Site & E. osburni & E. variatum & $\begin{array}{c}\text { F1 } \\
\text { Hybrid }\end{array}$ & $\begin{array}{c}\text { F2 } \\
\text { Hybrid }\end{array}$ & $\begin{array}{c}\text { Backcross w/ } \\
\text { E. osburni }\end{array}$ & $\begin{array}{c}\text { Backcross w/ } \\
\text { E. variatum }\end{array}$ \\
\hline 3 & 0.999 & 0.000 & 0.000 & 0.000 & 0.001 & 0.000 \\
\hline 3 & 0.999 & 0.000 & 0.000 & 0.000 & 0.001 & 0.000 \\
\hline 3 & 0.999 & 0.000 & 0.000 & 0.000 & 0.001 & 0.000 \\
\hline 3 & 0.999 & 0.000 & 0.000 & 0.000 & 0.001 & 0.000 \\
\hline 3 & 0.999 & 0.000 & 0.000 & 0.000 & 0.001 & 0.000 \\
\hline 3 & 0.999 & 0.000 & 0.000 & 0.000 & 0.001 & 0.000 \\
\hline 3 & 0.788 & 0.000 & 0.000 & 0.004 & 0.208 & 0.000 \\
\hline 3 & 0.999 & 0.000 & 0.000 & 0.000 & 0.001 & 0.000 \\
\hline 3 & 0.999 & 0.000 & 0.000 & 0.000 & 0.001 & 0.000 \\
\hline 3 & 0.823 & 0.000 & 0.000 & 0.004 & 0.173 & 0.000 \\
\hline 3 & 0.999 & 0.000 & 0.000 & 0.000 & 0.001 & 0.000 \\
\hline 3 & 0.999 & 0.000 & 0.000 & 0.000 & 0.001 & 0.000 \\
\hline 3 & 0.999 & 0.000 & 0.000 & 0.000 & 0.001 & 0.000 \\
\hline 3 & 0.999 & 0.000 & 0.000 & 0.000 & 0.001 & 0.000 \\
\hline 3 & 0.999 & 0.000 & 0.000 & 0.000 & 0.001 & 0.000 \\
\hline 3 & 0.999 & 0.000 & 0.000 & 0.000 & 0.001 & 0.000 \\
\hline 3 & 0.999 & 0.000 & 0.000 & 0.000 & 0.001 & 0.000 \\
\hline 3 & 0.999 & 0.000 & 0.000 & 0.000 & 0.001 & 0.000 \\
\hline 3 & 0.999 & 0.000 & 0.000 & 0.000 & 0.001 & 0.000 \\
\hline 3 & 0.999 & 0.000 & 0.000 & 0.000 & 0.001 & 0.000 \\
\hline 3 & 0.999 & 0.000 & 0.000 & 0.000 & 0.001 & 0.000 \\
\hline 3 & 0.999 & 0.000 & 0.000 & 0.000 & 0.002 & 0.000 \\
\hline 3 & 0.999 & 0.000 & 0.000 & 0.000 & 0.001 & 0.000 \\
\hline 3 & 0.295 & 0.000 & 0.000 & 0.023 & 0.682 & 0.000 \\
\hline 3 & 0.999 & 0.000 & 0.000 & 0.000 & 0.001 & 0.000 \\
\hline 3 & 0.998 & 0.000 & 0.000 & 0.000 & 0.002 & 0.000 \\
\hline 3 & 0.792 & 0.000 & 0.000 & 0.003 & 0.205 & 0.000 \\
\hline 3 & 0.999 & 0.000 & 0.000 & 0.000 & 0.001 & 0.000 \\
\hline 3 & 0.999 & 0.000 & 0.000 & 0.000 & 0.001 & 0.000 \\
\hline 3 & 0.999 & 0.000 & 0.000 & 0.000 & 0.001 & 0.000 \\
\hline 3 & 0.999 & 0.000 & 0.000 & 0.000 & 0.001 & 0.000 \\
\hline 2 & 0.000 & 0.994 & 0.000 & 0.000 & 0.000 & 0.006 \\
\hline 2 & 0.000 & 0.994 & 0.000 & 0.000 & 0.000 & 0.006 \\
\hline 2 & 0.000 & 0.842 & 0.000 & 0.001 & 0.000 & 0.157 \\
\hline 2 & 0.000 & 0.994 & 0.000 & 0.000 & 0.000 & 0.006 \\
\hline 2 & 0.000 & 0.000 & 0.007 & 0.353 & 0.029 & 0.610 \\
\hline 2 & 0.000 & 0.994 & 0.000 & 0.000 & 0.000 & 0.006 \\
\hline 2 & 0.000 & 0.000 & 0.003 & 0.204 & 0.002 & 0.791 \\
\hline 2 & 0.000 & 0.668 & 0.000 & 0.003 & 0.000 & 0.329 \\
\hline 2 & 0.000 & 0.994 & 0.000 & 0.000 & 0.000 & 0.006 \\
\hline 2 & 0.000 & 0.965 & 0.000 & 0.000 & 0.000 & 0.035 \\
\hline 2 & 0.000 & 0.994 & 0.000 & 0.000 & 0.000 & 0.006 \\
\hline 2 & 0.000 & 0.004 & 0.000 & 0.041 & 0.000 & 0.955 \\
\hline
\end{tabular}




\begin{tabular}{|c|c|c|c|c|c|c|}
\hline Site & E. osburni & E. variatum & $\begin{array}{c}\text { F1 } \\
\text { Hybrid }\end{array}$ & $\begin{array}{c}\text { F2 } \\
\text { Hybrid }\end{array}$ & $\begin{array}{c}\text { Backcross w/ } \\
\text { E. osburni }\end{array}$ & $\begin{array}{l}\text { Backcross w/ } \\
\text { E. variatum }\end{array}$ \\
\hline 2 & 0.000 & 0.978 & 0.000 & 0.000 & 0.000 & 0.022 \\
\hline 2 & 0.000 & 0.000 & 0.004 & 0.166 & 0.002 & 0.828 \\
\hline 2 & 0.000 & 0.000 & 0.511 & 0.052 & 0.321 & 0.116 \\
\hline 2 & 0.000 & 0.977 & 0.000 & 0.000 & 0.000 & 0.023 \\
\hline 2 & 0.000 & 0.994 & 0.000 & 0.000 & 0.000 & 0.006 \\
\hline 2 & 0.000 & 0.977 & 0.000 & 0.000 & 0.000 & 0.023 \\
\hline 2 & 0.000 & 0.190 & 0.000 & 0.010 & 0.000 & 0.801 \\
\hline 2 & 0.000 & 0.994 & 0.000 & 0.000 & 0.000 & 0.006 \\
\hline 2 & 0.000 & 0.978 & 0.000 & 0.000 & 0.000 & 0.022 \\
\hline 2 & 0.000 & 0.994 & 0.000 & 0.000 & 0.000 & 0.006 \\
\hline 2 & 0.000 & 0.849 & 0.000 & 0.001 & 0.000 & 0.150 \\
\hline 2 & 0.000 & 0.967 & 0.000 & 0.000 & 0.000 & 0.033 \\
\hline 2 & 0.000 & 0.019 & 0.000 & 0.023 & 0.000 & 0.958 \\
\hline 2 & 0.000 & 0.000 & 0.655 & 0.026 & 0.077 & 0.243 \\
\hline 2 & 0.000 & 0.993 & 0.000 & 0.000 & 0.000 & 0.007 \\
\hline 2 & 0.000 & 0.994 & 0.000 & 0.000 & 0.000 & 0.006 \\
\hline 2 & 0.000 & 0.000 & 0.701 & 0.024 & 0.089 & 0.186 \\
\hline 2 & 0.000 & 0.305 & 0.000 & 0.022 & 0.000 & 0.674 \\
\hline 2 & 0.000 & 0.994 & 0.000 & 0.000 & 0.000 & 0.006 \\
\hline 2 & 0.000 & 0.966 & 0.000 & 0.000 & 0.000 & 0.033 \\
\hline 2 & 0.000 & 0.978 & 0.000 & 0.000 & 0.000 & 0.022 \\
\hline 1 & 0.000 & 0.978 & 0.000 & 0.000 & 0.000 & 0.022 \\
\hline 1 & 0.000 & 0.994 & 0.000 & 0.000 & 0.000 & 0.006 \\
\hline 1 & 0.000 & 0.072 & 0.000 & 0.034 & 0.000 & 0.894 \\
\hline 1 & 0.000 & 0.994 & 0.000 & 0.000 & 0.000 & 0.006 \\
\hline 1 & 0.000 & 0.975 & 0.000 & 0.000 & 0.000 & 0.025 \\
\hline 1 & 0.000 & 0.880 & 0.000 & 0.001 & 0.000 & 0.119 \\
\hline 1 & 0.000 & 0.883 & 0.000 & 0.002 & 0.000 & 0.116 \\
\hline 1 & 0.000 & 0.994 & 0.000 & 0.000 & 0.000 & 0.006 \\
\hline 1 & 0.000 & 0.373 & 0.000 & 0.012 & 0.000 & 0.616 \\
\hline 1 & 0.000 & 0.994 & 0.000 & 0.000 & 0.000 & 0.006 \\
\hline 1 & 0.000 & 0.881 & 0.000 & 0.001 & 0.000 & 0.118 \\
\hline 1 & 0.000 & 0.994 & 0.000 & 0.000 & 0.000 & 0.006 \\
\hline 1 & 0.000 & 0.176 & 0.000 & 0.026 & 0.000 & 0.798 \\
\hline 1 & 0.000 & 0.586 & 0.000 & 0.009 & 0.000 & 0.405 \\
\hline 1 & 0.000 & 0.513 & 0.000 & 0.005 & 0.000 & 0.482 \\
\hline 1 & 0.000 & 0.994 & 0.000 & 0.000 & 0.000 & 0.006 \\
\hline 1 & 0.000 & 0.978 & 0.000 & 0.000 & 0.000 & 0.022 \\
\hline 12 & 0.000 & 0.994 & 0.000 & 0.000 & 0.000 & 0.006 \\
\hline 12 & 0.000 & 0.994 & 0.000 & 0.000 & 0.000 & 0.006 \\
\hline 12 & 0.000 & 0.978 & 0.000 & 0.000 & 0.000 & 0.022 \\
\hline 12 & 0.000 & 0.994 & 0.000 & 0.000 & 0.000 & 0.006 \\
\hline 12 & 0.000 & 0.967 & 0.000 & 0.000 & 0.000 & 0.033 \\
\hline
\end{tabular}




\begin{tabular}{|c|c|c|c|c|c|c|}
\hline Site & E. osburni & E. variatum & $\begin{array}{c}\text { F1 } \\
\text { Hybrid }\end{array}$ & $\begin{array}{c}\text { F2 } \\
\text { Hybrid }\end{array}$ & $\begin{array}{c}\text { Backcross w/ } \\
\text { E. osburni }\end{array}$ & $\begin{array}{c}\text { Backcross w/ } \\
\text { E. variatum }\end{array}$ \\
\hline 12 & 0.000 & 0.994 & 0.000 & 0.000 & 0.000 & 0.006 \\
\hline 12 & 0.000 & 0.994 & 0.000 & 0.000 & 0.000 & 0.006 \\
\hline 12 & 0.000 & 0.994 & 0.000 & 0.000 & 0.000 & 0.006 \\
\hline 12 & 0.000 & 0.994 & 0.000 & 0.000 & 0.000 & 0.006 \\
\hline 12 & 0.000 & 0.994 & 0.000 & 0.000 & 0.000 & 0.006 \\
\hline 12 & 0.000 & 0.994 & 0.000 & 0.000 & 0.000 & 0.006 \\
\hline 12 & 0.000 & 0.994 & 0.000 & 0.000 & 0.000 & 0.006 \\
\hline 12 & 0.000 & 0.994 & 0.000 & 0.000 & 0.000 & 0.006 \\
\hline 12 & 0.000 & 0.994 & 0.000 & 0.000 & 0.000 & 0.006 \\
\hline 12 & 0.000 & 0.994 & 0.000 & 0.000 & 0.000 & 0.006 \\
\hline 12 & 0.000 & 0.994 & 0.000 & 0.000 & 0.000 & 0.006 \\
\hline 12 & 0.000 & 0.994 & 0.000 & 0.000 & 0.000 & 0.006 \\
\hline 12 & 0.000 & 0.994 & 0.000 & 0.000 & 0.000 & 0.006 \\
\hline 12 & 0.000 & 0.849 & 0.000 & 0.001 & 0.000 & 0.150 \\
\hline 12 & 0.000 & 0.978 & 0.000 & 0.000 & 0.000 & 0.022 \\
\hline 12 & 0.000 & 0.994 & 0.000 & 0.000 & 0.000 & 0.006 \\
\hline 12 & 0.000 & 0.994 & 0.000 & 0.000 & 0.000 & 0.006 \\
\hline 12 & 0.000 & 0.994 & 0.000 & 0.000 & 0.000 & 0.006 \\
\hline 12 & 0.000 & 0.994 & 0.000 & 0.000 & 0.000 & 0.006 \\
\hline 12 & 0.000 & 0.994 & 0.000 & 0.000 & 0.000 & 0.006 \\
\hline 12 & 0.000 & 0.978 & 0.000 & 0.000 & 0.000 & 0.022 \\
\hline 12 & 0.000 & 0.994 & 0.000 & 0.000 & 0.000 & 0.006 \\
\hline 12 & 0.000 & 0.994 & 0.000 & 0.000 & 0.000 & 0.006 \\
\hline 12 & 0.000 & 0.379 & 0.000 & 0.007 & 0.000 & 0.614 \\
\hline 12 & 0.000 & 0.994 & 0.000 & 0.000 & 0.000 & 0.006 \\
\hline 12 & 0.000 & 0.994 & 0.000 & 0.000 & 0.000 & 0.006 \\
\hline $13,14,15$ & 0.000 & 0.978 & 0.000 & 0.000 & 0.000 & 0.022 \\
\hline $13,14,15$ & 0.000 & 0.994 & 0.000 & 0.000 & 0.000 & 0.006 \\
\hline $13,14,15$ & 0.000 & 0.994 & 0.000 & 0.000 & 0.000 & 0.006 \\
\hline $13,14,15$ & 0.000 & 0.994 & 0.000 & 0.000 & 0.000 & 0.006 \\
\hline $13,14,15$ & 0.000 & 0.994 & 0.000 & 0.000 & 0.000 & 0.006 \\
\hline $13,14,15$ & 0.000 & 0.994 & 0.000 & 0.000 & 0.000 & 0.006 \\
\hline $13,14,15$ & 0.000 & 0.994 & 0.000 & 0.000 & 0.000 & 0.006 \\
\hline $13,14,15$ & 0.000 & 0.994 & 0.000 & 0.000 & 0.000 & 0.006 \\
\hline $13,14,15$ & 0.000 & 0.994 & 0.000 & 0.000 & 0.000 & 0.006 \\
\hline $13,14,15$ & 0.000 & 0.978 & 0.000 & 0.000 & 0.000 & 0.022 \\
\hline $13,14,15$ & 0.000 & 0.994 & 0.000 & 0.000 & 0.000 & 0.006 \\
\hline $13,14,15$ & 0.000 & 0.881 & 0.000 & 0.001 & 0.000 & 0.119 \\
\hline $13,14,15$ & 0.000 & 0.836 & 0.000 & 0.002 & 0.000 & 0.162 \\
\hline $13,14,15$ & 0.000 & 0.994 & 0.000 & 0.000 & 0.000 & 0.006 \\
\hline $13,14,15$ & 0.000 & 0.961 & 0.000 & 0.001 & 0.000 & 0.037 \\
\hline $13,14,15$ & 0.000 & 0.978 & 0.000 & 0.000 & 0.000 & 0.022 \\
\hline $13,14,15$ & 0.000 & 0.880 & 0.000 & 0.001 & 0.000 & 0.119 \\
\hline
\end{tabular}




\begin{tabular}{|c|c|c|c|c|c|c|}
\hline Site & E. osburni & E. variatum & $\begin{array}{c}\text { F1 } \\
\text { Hybrid }\end{array}$ & $\begin{array}{c}\text { F2 } \\
\text { Hybrid }\end{array}$ & $\begin{array}{c}\text { Backcross w/ } \\
\text { E. osburni }\end{array}$ & $\begin{array}{c}\text { Backcross w/ } \\
\text { E. variatum }\end{array}$ \\
\hline $13,14,15$ & 0.000 & 0.881 & 0.000 & 0.001 & 0.000 & 0.118 \\
\hline $13,14,15$ & 0.000 & 0.994 & 0.000 & 0.000 & 0.000 & 0.006 \\
\hline 16 & 0.000 & 0.000 & 0.038 & 0.067 & 0.003 & 0.893 \\
\hline 16 & 0.000 & 0.000 & 0.061 & 0.151 & 0.029 & 0.759 \\
\hline 16 & 0.999 & 0.000 & 0.000 & 0.000 & 0.001 & 0.000 \\
\hline 16 & 0.138 & 0.000 & 0.001 & 0.049 & 0.812 & 0.000 \\
\hline 16 & 0.000 & 0.000 & 0.660 & 0.026 & 0.079 & 0.236 \\
\hline 16 & 0.000 & 0.000 & 0.068 & 0.141 & 0.776 & 0.016 \\
\hline 16 & 0.000 & 0.994 & 0.000 & 0.000 & 0.000 & 0.006 \\
\hline 17 & 0.999 & 0.000 & 0.000 & 0.000 & 0.001 & 0.000 \\
\hline 17 & 0.851 & 0.000 & 0.000 & 0.003 & 0.146 & 0.000 \\
\hline 17 & 0.999 & 0.000 & 0.000 & 0.000 & 0.001 & 0.000 \\
\hline 17 & 0.999 & 0.000 & 0.000 & 0.000 & 0.001 & 0.000 \\
\hline 17 & 0.999 & 0.000 & 0.000 & 0.000 & 0.002 & 0.000 \\
\hline 18 & 0.848 & 0.000 & 0.000 & 0.003 & 0.149 & 0.000 \\
\hline 18 & 0.999 & 0.000 & 0.000 & 0.000 & 0.001 & 0.000 \\
\hline 18 & 0.999 & 0.000 & 0.000 & 0.000 & 0.002 & 0.000 \\
\hline 18 & 0.999 & 0.000 & 0.000 & 0.000 & 0.001 & 0.000 \\
\hline 18 & 0.998 & 0.000 & 0.000 & 0.000 & 0.002 & 0.000 \\
\hline 18 & 0.999 & 0.000 & 0.000 & 0.000 & 0.002 & 0.000 \\
\hline 18 & 0.999 & 0.000 & 0.000 & 0.000 & 0.001 & 0.000 \\
\hline 18 & 0.999 & 0.000 & 0.000 & 0.000 & 0.001 & 0.000 \\
\hline 18 & 0.999 & 0.000 & 0.000 & 0.000 & 0.002 & 0.000 \\
\hline 18 & 0.999 & 0.000 & 0.000 & 0.000 & 0.001 & 0.000 \\
\hline 18 & 0.999 & 0.000 & 0.000 & 0.000 & 0.001 & 0.000 \\
\hline 18 & 0.999 & 0.000 & 0.000 & 0.000 & 0.002 & 0.000 \\
\hline 18 & 0.999 & 0.000 & 0.000 & 0.000 & 0.001 & 0.000 \\
\hline 19 & 0.999 & 0.000 & 0.000 & 0.000 & 0.002 & 0.000 \\
\hline 19 & 0.000 & 0.000 & 0.652 & 0.026 & 0.076 & 0.246 \\
\hline 19 & 0.999 & 0.000 & 0.000 & 0.000 & 0.001 & 0.000 \\
\hline 19 & 0.999 & 0.000 & 0.000 & 0.000 & 0.002 & 0.000 \\
\hline 19 & 0.999 & 0.000 & 0.000 & 0.000 & 0.001 & 0.000 \\
\hline 19 & 0.999 & 0.000 & 0.000 & 0.000 & 0.002 & 0.000 \\
\hline 19 & 0.815 & 0.000 & 0.000 & 0.004 & 0.181 & 0.000 \\
\hline 19 & 0.999 & 0.000 & 0.000 & 0.000 & 0.001 & 0.000 \\
\hline 19 & 0.999 & 0.000 & 0.000 & 0.000 & 0.001 & 0.000 \\
\hline 19 & 0.118 & 0.000 & 0.000 & 0.055 & 0.827 & 0.000 \\
\hline 19 & 0.000 & 0.000 & 0.001 & 0.104 & 0.895 & 0.000 \\
\hline 19 & 0.999 & 0.000 & 0.000 & 0.000 & 0.002 & 0.000 \\
\hline 20 & 0.999 & 0.000 & 0.000 & 0.000 & 0.002 & 0.000 \\
\hline 20 & 0.999 & 0.000 & 0.000 & 0.000 & 0.001 & 0.000 \\
\hline 20 & 0.999 & 0.000 & 0.000 & 0.000 & 0.001 & 0.000 \\
\hline 20 & 0.999 & 0.000 & 0.000 & 0.000 & 0.001 & 0.000 \\
\hline
\end{tabular}




\begin{tabular}{|c|c|c|c|c|c|c|}
\hline Site & E. osburni & E. variatum & $\begin{array}{c}\text { F1 } \\
\text { Hybrid }\end{array}$ & $\begin{array}{c}\text { F2 } \\
\text { Hybrid }\end{array}$ & $\begin{array}{c}\text { Backcross w/ } \\
\text { E. osburni }\end{array}$ & $\begin{array}{c}\text { Backcross w/ } \\
\text { E. variatum }\end{array}$ \\
\hline 20 & 0.999 & 0.000 & 0.000 & 0.000 & 0.002 & 0.000 \\
\hline 21 & 0.998 & 0.000 & 0.000 & 0.000 & 0.002 & 0.000 \\
\hline 21 & 0.999 & 0.000 & 0.000 & 0.000 & 0.001 & 0.000 \\
\hline 21 & 0.945 & 0.000 & 0.000 & 0.002 & 0.054 & 0.000 \\
\hline 21 & 0.999 & 0.000 & 0.000 & 0.000 & 0.001 & 0.000 \\
\hline 21 & 0.999 & 0.000 & 0.000 & 0.000 & 0.001 & 0.000 \\
\hline 21 & 0.999 & 0.000 & 0.000 & 0.000 & 0.002 & 0.000 \\
\hline 21 & 0.999 & 0.000 & 0.000 & 0.000 & 0.002 & 0.000 \\
\hline 21 & 0.999 & 0.000 & 0.000 & 0.000 & 0.001 & 0.000 \\
\hline 21 & 0.853 & 0.000 & 0.000 & 0.003 & 0.144 & 0.000 \\
\hline 21 & 0.999 & 0.000 & 0.000 & 0.000 & 0.002 & 0.000 \\
\hline 21 & 0.999 & 0.000 & 0.000 & 0.000 & 0.001 & 0.000 \\
\hline 21 & 0.999 & 0.000 & 0.000 & 0.000 & 0.002 & 0.000 \\
\hline 21 & 0.999 & 0.000 & 0.000 & 0.000 & 0.001 & 0.000 \\
\hline 21 & 0.999 & 0.000 & 0.000 & 0.000 & 0.001 & 0.000 \\
\hline 21 & 0.999 & 0.000 & 0.000 & 0.000 & 0.002 & 0.000 \\
\hline 21 & 0.999 & 0.000 & 0.000 & 0.000 & 0.002 & 0.000 \\
\hline 21 & 0.999 & 0.000 & 0.000 & 0.000 & 0.001 & 0.000 \\
\hline 21 & 0.999 & 0.000 & 0.000 & 0.000 & 0.001 & 0.000 \\
\hline 21 & 0.998 & 0.000 & 0.000 & 0.000 & 0.002 & 0.000 \\
\hline 21 & 0.999 & 0.000 & 0.000 & 0.000 & 0.001 & 0.000 \\
\hline 21 & 0.999 & 0.000 & 0.000 & 0.000 & 0.001 & 0.000 \\
\hline 21 & 0.999 & 0.000 & 0.000 & 0.000 & 0.001 & 0.000 \\
\hline 21 & 0.999 & 0.000 & 0.000 & 0.000 & 0.002 & 0.000 \\
\hline 21 & 0.998 & 0.000 & 0.000 & 0.000 & 0.002 & 0.000 \\
\hline 21 & 0.999 & 0.000 & 0.000 & 0.000 & 0.001 & 0.000 \\
\hline 21 & 0.999 & 0.000 & 0.000 & 0.000 & 0.002 & 0.000 \\
\hline 21 & 0.999 & 0.000 & 0.000 & 0.000 & 0.001 & 0.000 \\
\hline 21 & 0.999 & 0.000 & 0.000 & 0.000 & 0.001 & 0.000 \\
\hline 21 & 0.999 & 0.000 & 0.000 & 0.000 & 0.001 & 0.000 \\
\hline 21 & 0.999 & 0.000 & 0.000 & 0.000 & 0.002 & 0.000 \\
\hline 21 & 0.999 & 0.000 & 0.000 & 0.000 & 0.001 & 0.000 \\
\hline 22 & 0.999 & 0.000 & 0.000 & 0.000 & 0.001 & 0.000 \\
\hline 22 & 0.999 & 0.000 & 0.000 & 0.000 & 0.001 & 0.000 \\
\hline 22 & 0.998 & 0.000 & 0.000 & 0.000 & 0.002 & 0.000 \\
\hline 22 & 0.000 & 0.000 & 0.006 & 0.101 & 0.893 & 0.001 \\
\hline 22 & 0.998 & 0.000 & 0.000 & 0.000 & 0.002 & 0.000 \\
\hline 22 & 0.999 & 0.000 & 0.000 & 0.000 & 0.001 & 0.000 \\
\hline 22 & 0.999 & 0.000 & 0.000 & 0.000 & 0.002 & 0.000 \\
\hline 22 & 0.998 & 0.000 & 0.000 & 0.000 & 0.002 & 0.000 \\
\hline 22 & 0.998 & 0.000 & 0.000 & 0.000 & 0.002 & 0.000 \\
\hline
\end{tabular}

